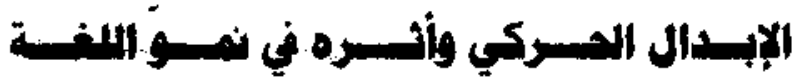 \\ د. علي بن عبدلابه الراجحي \\ أستاذ فته الاغة المساع في كلية الاغنة العربية \\ جامعة التصيم
}

\section{: ain}

الحمد الله الذي فضل الإنسان على كثير همن خلق تفضيلا ، وجعل بقرته اللسان على ودائع القلوب سليلأ . أحمده سبحانه وتعالى حمدأ يكون

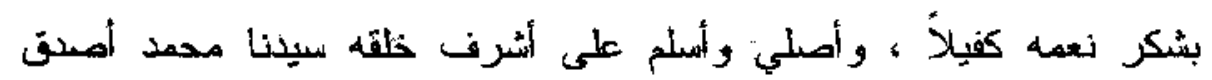

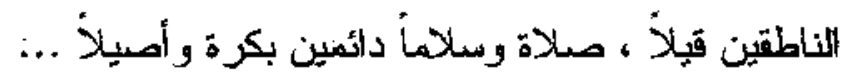
وبعـد

فإن لغتتا العربية - حفظها اله - أعظم اللغات البشرية جملة وتفصبلأ ، وخير شاهد على نلك أن أله سبحانه وتعالى قد اختصها فنزل بها المزرآن الكريم تبيانأ لكل شئيء و وتفيلاً .

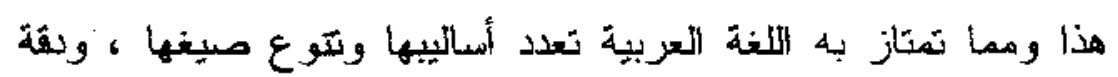

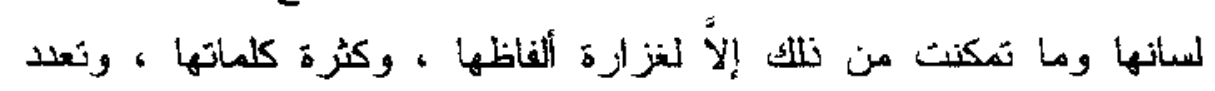
مفرداتها - ماتها وكان من أسبابب ذلك اللتميز نعدد روافد نموها ، وكثرة اللينابيع التي

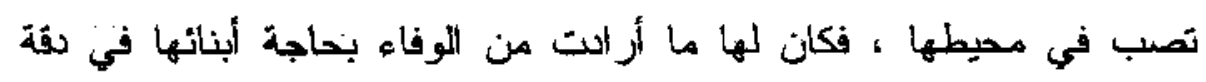

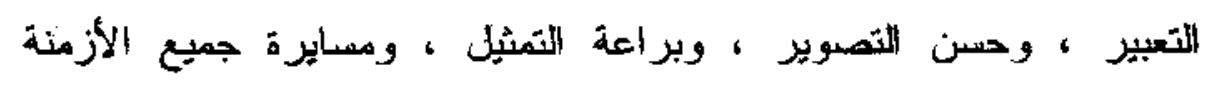

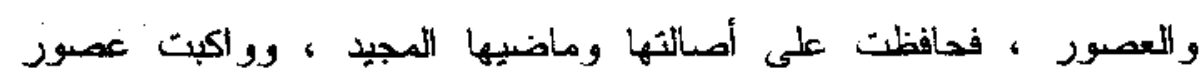

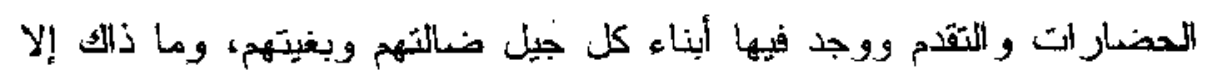
لغناها ورنز ائها 
و التغيير الحركي له صور متعدة ومنتوعة ، منه ما يكون على فاء

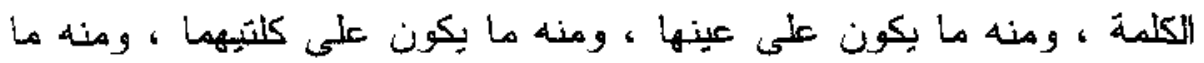
يكون بالحركات الثلاث ، ومنه ما يكون بحركتين وكل صورة من هذه

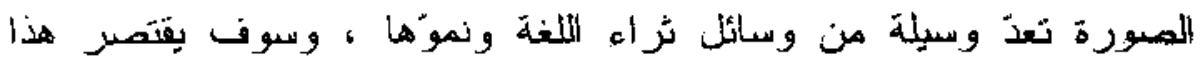
البحث على صورة و أحدة من هذه الصعور ، وهي ما كان منها على فاء

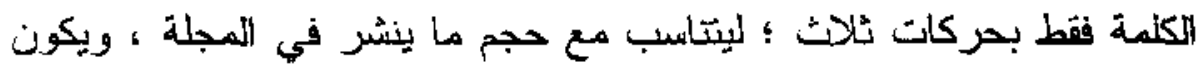

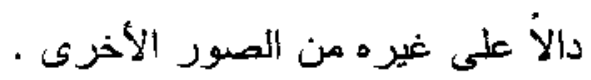
ومن عوامل نمو اللغة المتعدة والمتنوعة ما يلي :

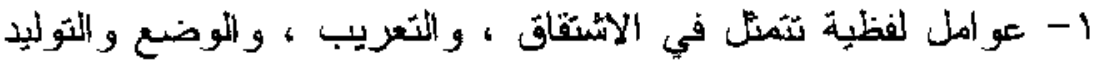
والإبدال ، وغير ها ل... r- عو امل معنوية تتمثل كما نرى في هذا ألبحث في التغيير الحركي

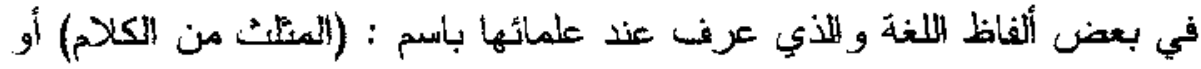

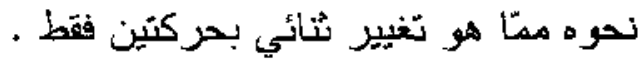

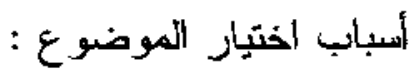
القد حملني على الكتابة في هذا الموضوع أسباب ودوافع كثيرة أذكر 1- الجرص على إناعة و إذاعة هذا اللون من مستعمل الككلام الذي كاد يندثر ، و الذي لا برى النور على أللسنة المتحشين باللغة العربية و الناطقين

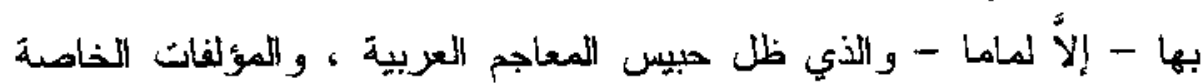

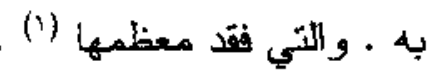

ونظر : المتلث لابن السيد /N/ ـ/ rا (المثلث لابن السيد البطليوسي ، تحتيق : د.

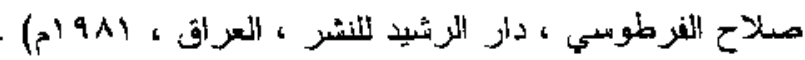


r- تتبيه الباحثين و الدارسين ، ولفت نظرهم إلى رقة ودقة لغتال

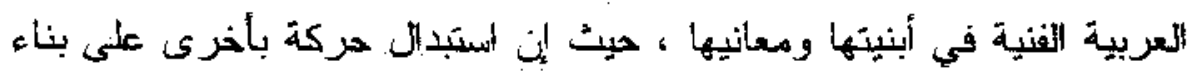

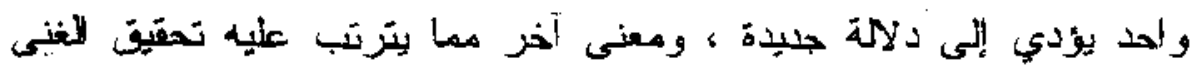

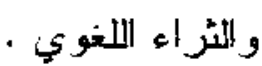

r- تنبيه انباحثين في اللغة و الابارسين لها إلى أن نمو لغتا العربية

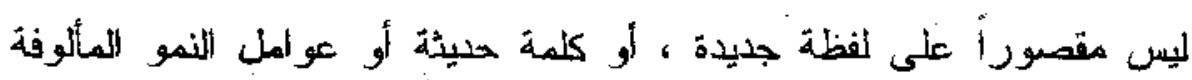

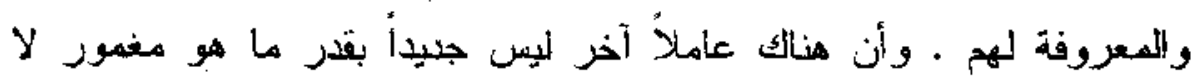

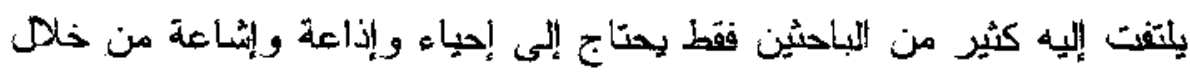

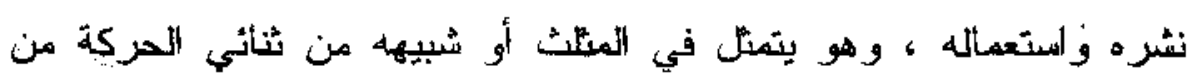

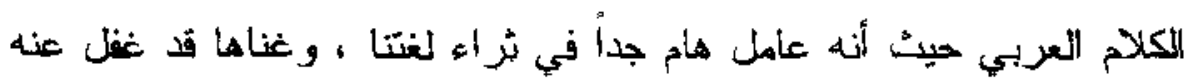

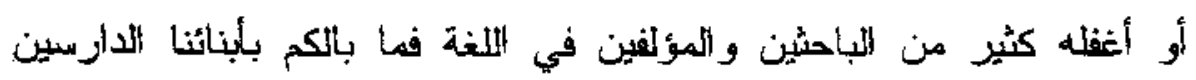

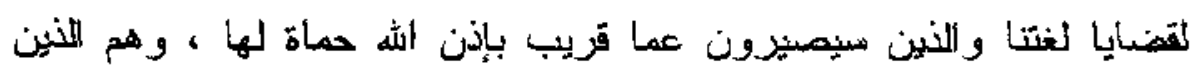

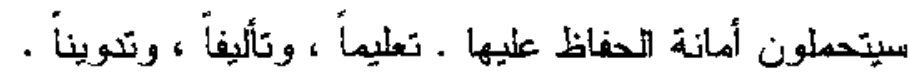

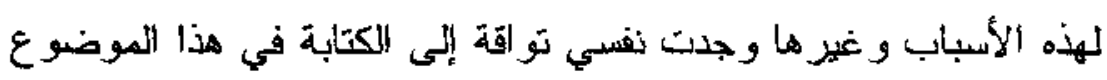

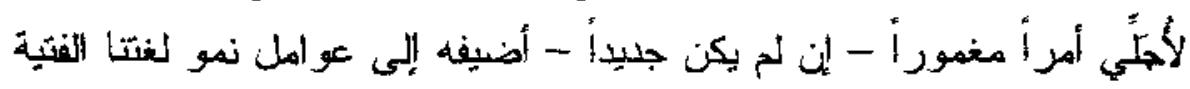

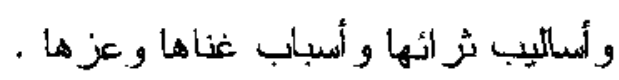

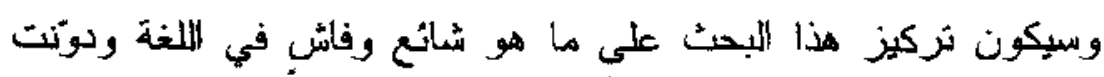

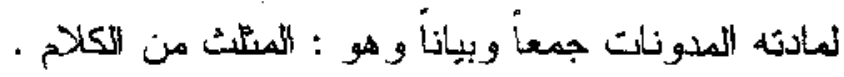

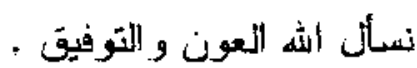

د. علي بن عبد الثه الثراجحي. 
تصريف المثلى :

إن من ينقب ويبحث في كتب اللغغة ليقف على آراء الكلماء في تعريف

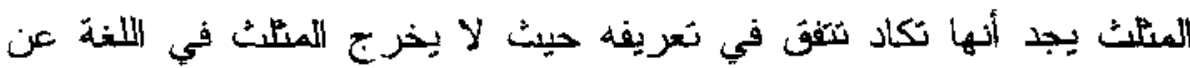

"ما كان من الأثياء على ثلاثة أثناء" (")

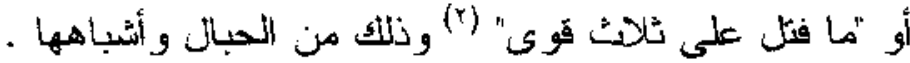

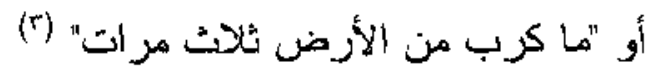

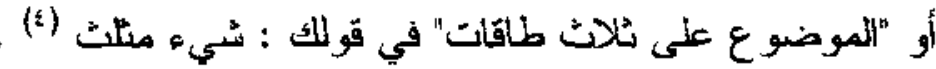

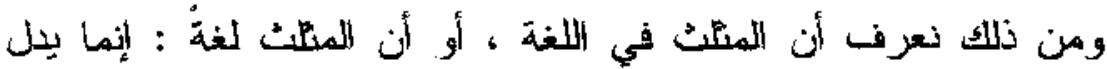

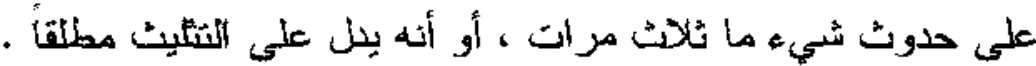

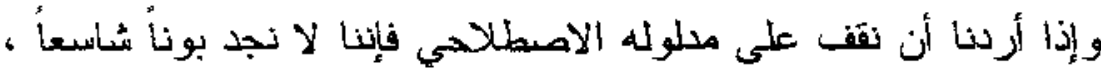

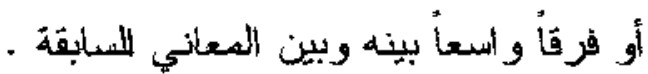

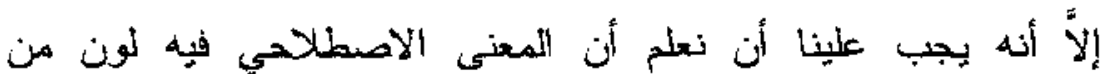

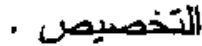
قال فريق من العلماء : "المتئ اسم برى في الكتابة واحدأ ويصرف على تنلائة أوجه" (0) من من

الآتهنيب 1//10 ، (تهذيب اللغة ، للأزهري ، ثحتيق : عبدالسلام هارون وآخرين ( مמر)

الاتهذيب 11/10 ، (تهذيب اللغة ، للأزهري ، تشيق : عبدالسلام هارون وآخرين ( مصر ، (1)

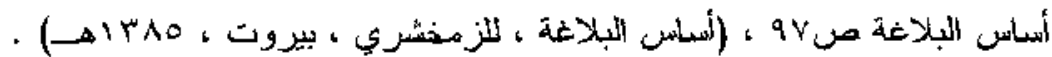

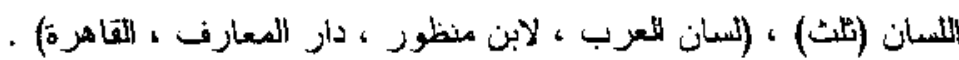

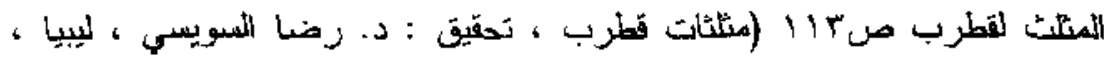


ومَال فريق آخر : "المنتث هو : ما اتفقت أوزانه وتعادلت أقسامه ولم

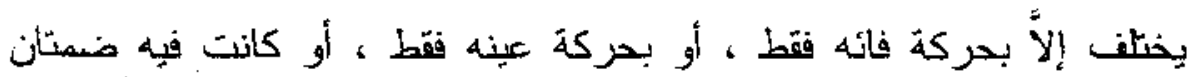

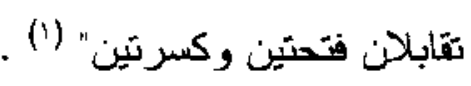

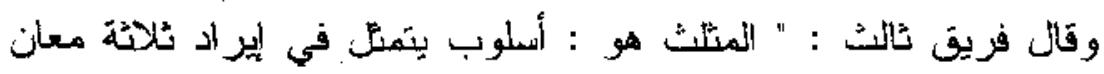

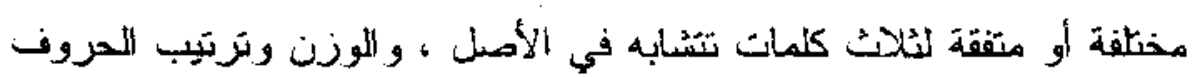

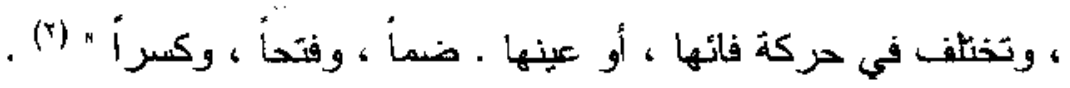

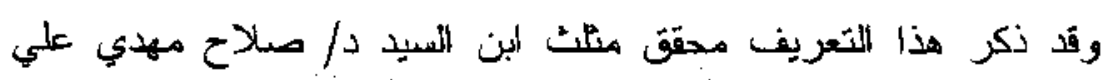

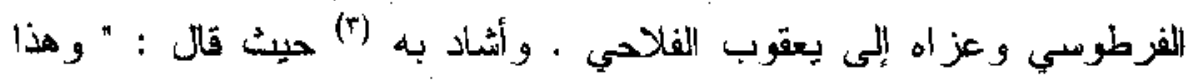

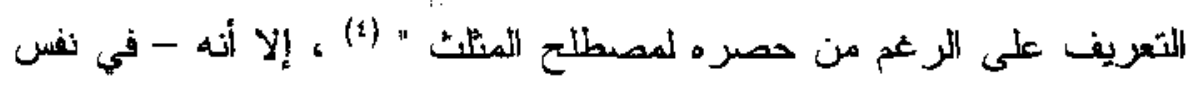

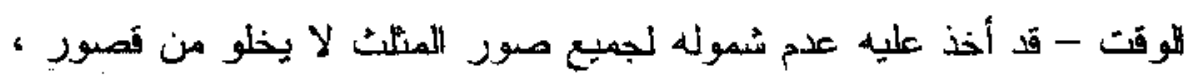

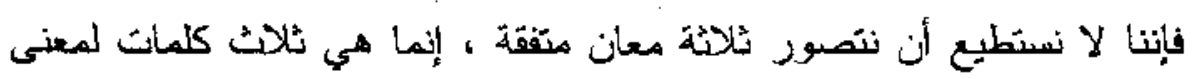

$$
\text { واحد . فئ. }
$$

كما أن هذا التعريف لا نكخل فيه الكلمات المبلنة متل : السمسم - بفتح

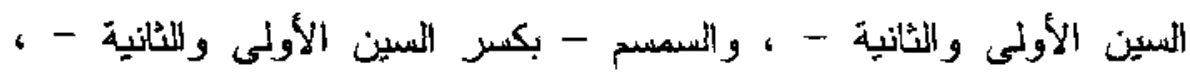

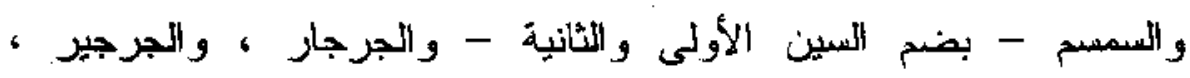

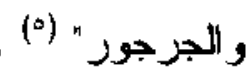

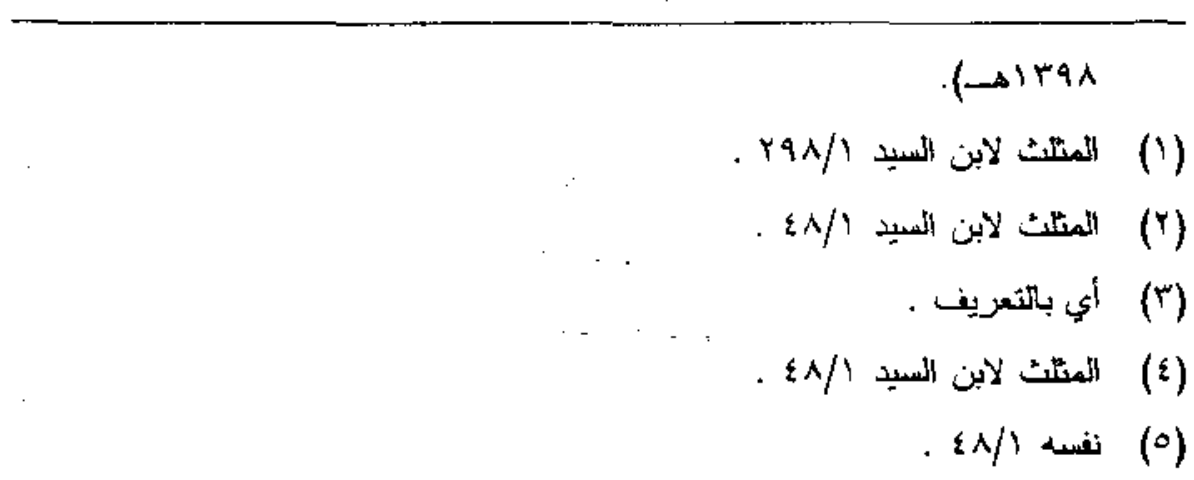




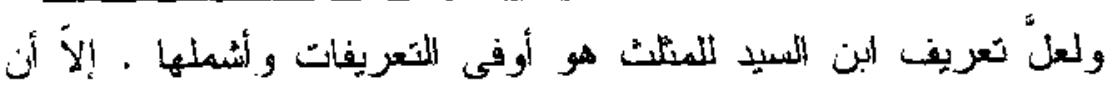

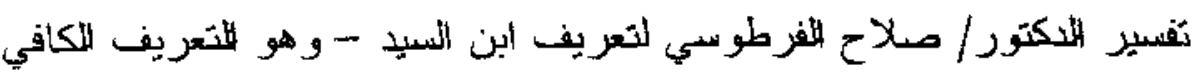

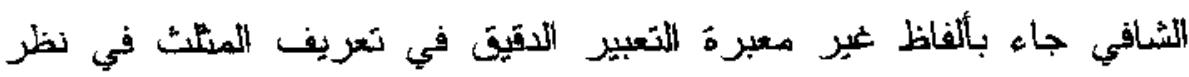

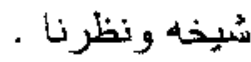

ولكي نقف على نلك بصورة جلية نعالو أمعنا ننستعرض معأ ما قاله

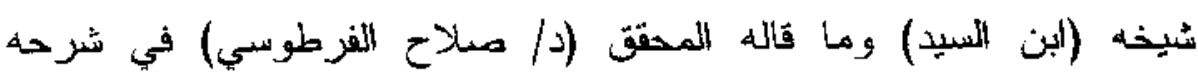
لتعريف شُيخه .

قال ابن السيد في تعريف العند الاصطلاحي : "هو ما اثفقت أوز انه

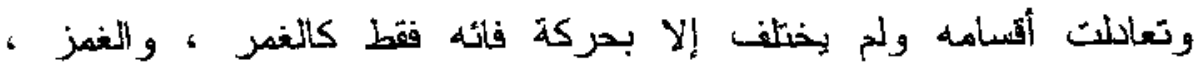

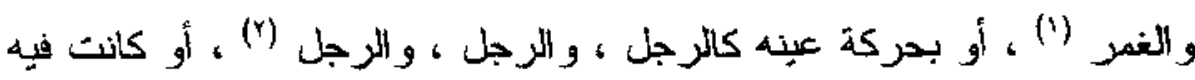

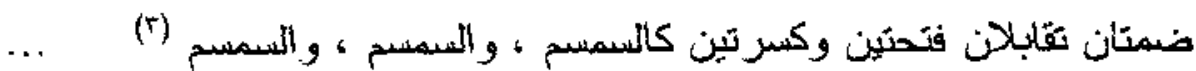

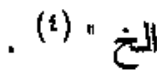

وهذا التعريف كما سبق أن قلنا : ثعريف كاف شاف ، جامع مانع حيث

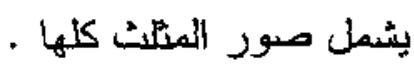

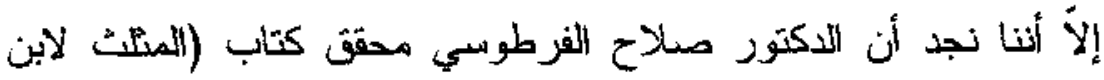

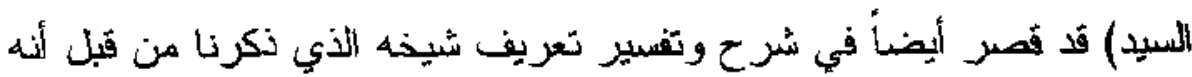

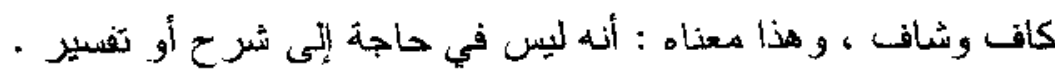

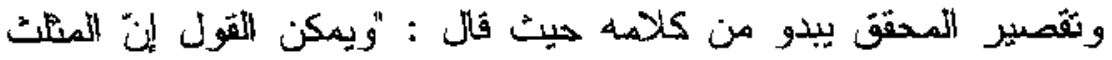

$$
\begin{aligned}
& \text { بفتح الغين وكسرها وضمها على المزتيب . } \\
& \text { بنتخ الجيم وكسر ها وضمهي على الترتيب . }
\end{aligned}
$$

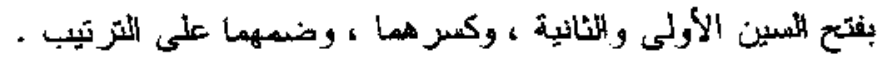

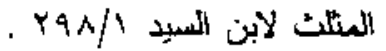


أسلوب ينمثل في إيراد ثلاث حركات لنثلاث كلمات تشتابه في الأصل و الموزن

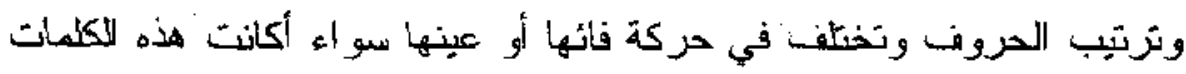

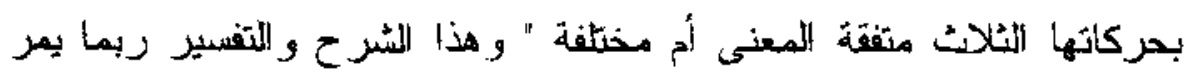
على كثير هن الباحثين و المطلعين على الكتاب دون أن يرى أحدهم فيه وليه تشيئا .

ولعل" المحققَ في هذا المقام أُتي من عدم دقته في اختبار الألفاظ الدقَيقة

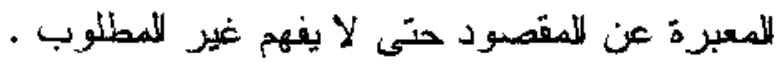

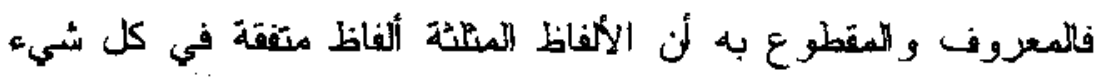
( في الحروف والثزتيب ) بل هي في المواقع كلمة واحدة اختلفت حركاتها

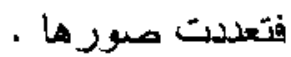

فكيف يمكن له بعد ذلك أن يقول : "لثنالث كلمات تتشابه" فقوله "تشتابه"

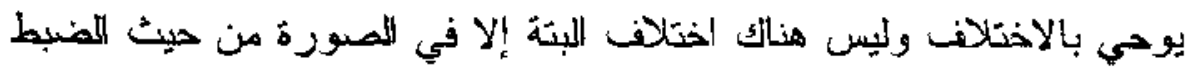

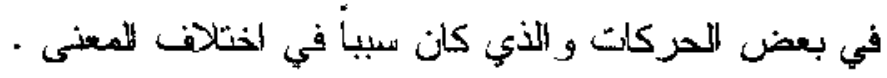

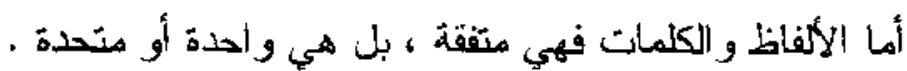

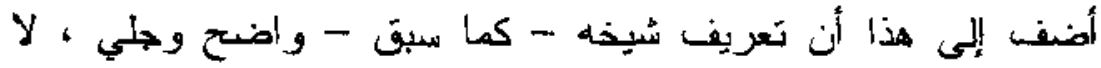

$$
\begin{aligned}
& \text { بحتاج إلمى شرح أو تعليق . } \\
& \text { أنواع المثلث من الكلام : }
\end{aligned}
$$

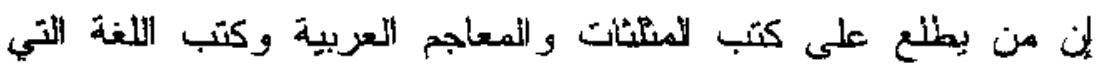

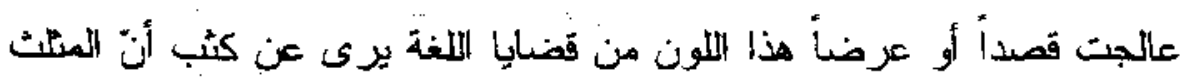

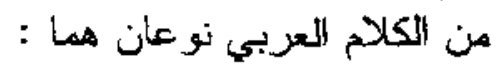

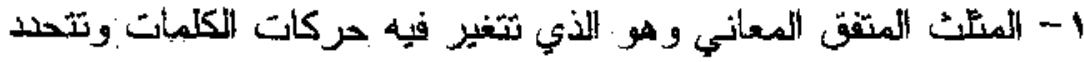

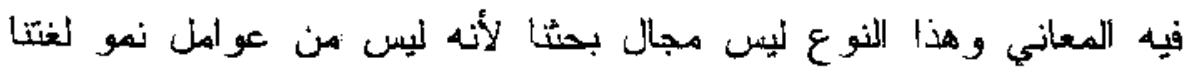
العربية . 
r- المثنت المختلف المعاني وهو الذي تتغير فيه بعض حركات

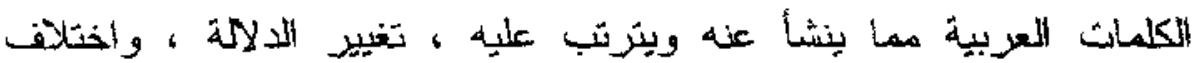
- المعاني و هذا اللون هو الذي نحن بصدد بهثه و المحتث عنه في هذا البحث لأثنه

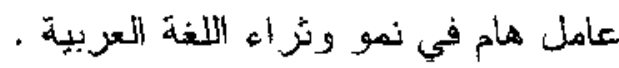

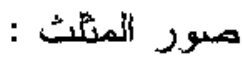

يزد المثند المختلف المعاني على عدة صور نوجزها فيما ليلي :

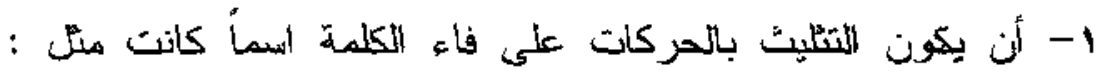

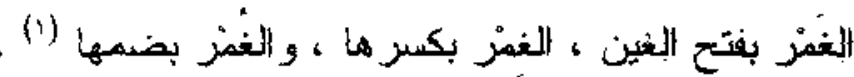

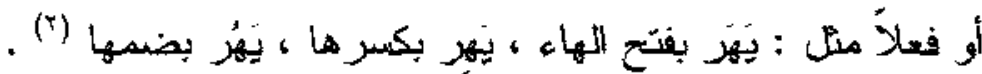

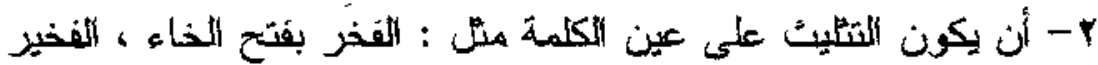

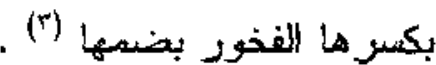

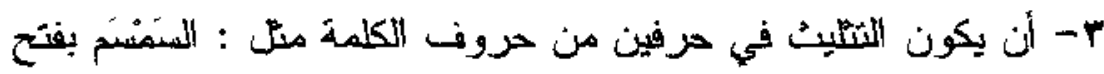

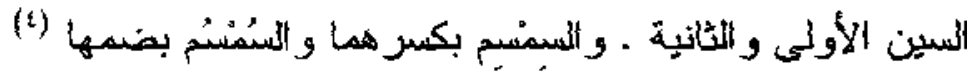

ينظر في شرهها وبيان معنى كل كلمة (باب الغين) من هذا البحتث .

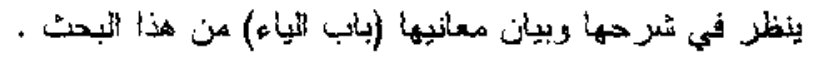

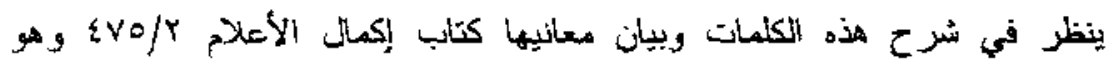

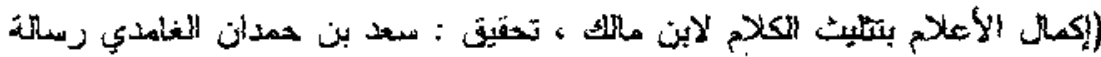

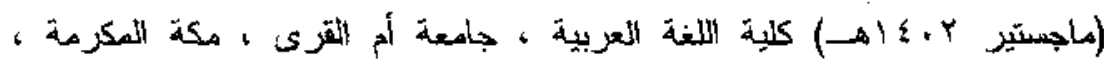

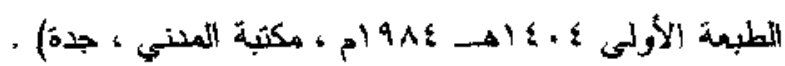

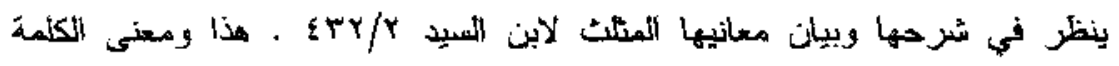

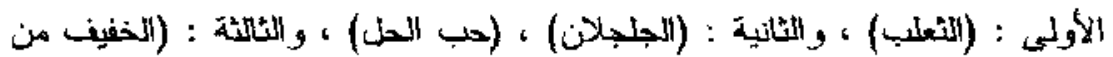

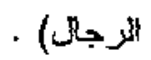


هذا وحسبنا في توُيق وتحقين هذه الصور قول العلامة اين العيد

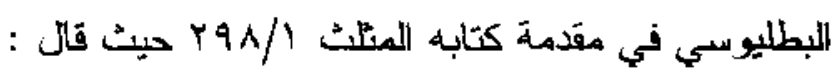

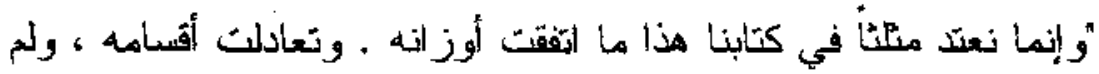

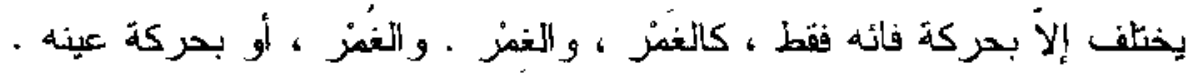

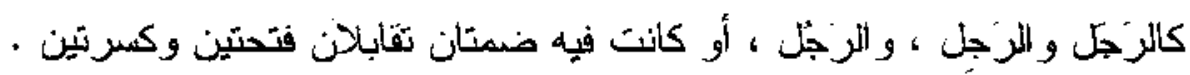

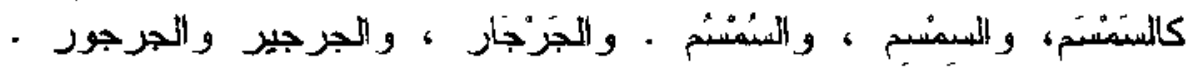

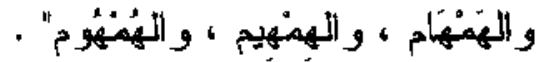
أشهر المؤلفات في المثلث :

لقد نعدث المؤلفات - ولان لم نكن بصورة كبيرة - في المثلث من

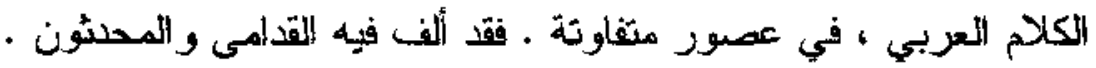

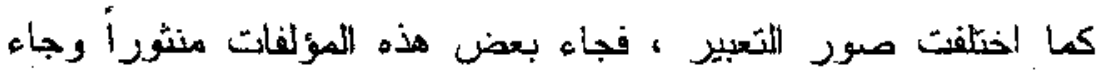
بعضها منظومأ.

وهذه صورة موجزة مفيدة بإذن الله لأشهر ما ألف في المثلت من الكلام

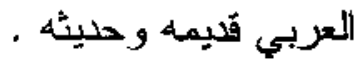

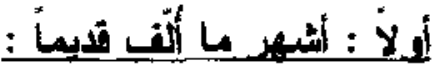

1- مثلث قطرب ، وهو أول مصنف في هذا المجال ، فلم يسبت

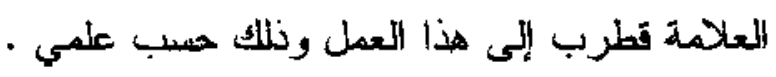

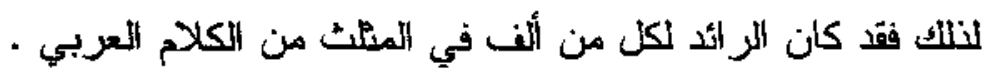

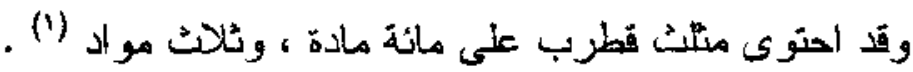

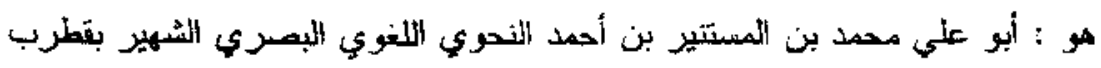

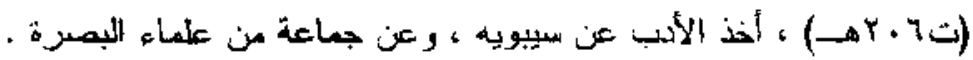

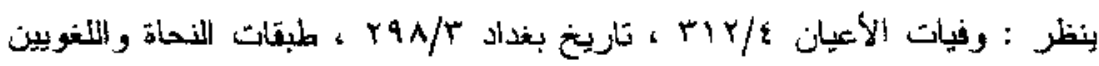

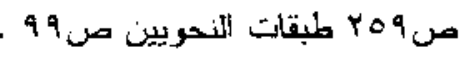




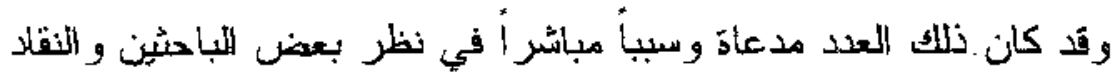

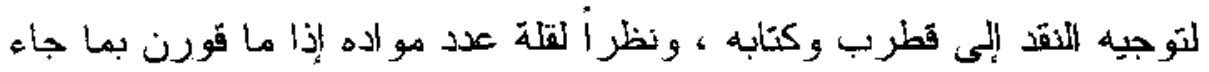

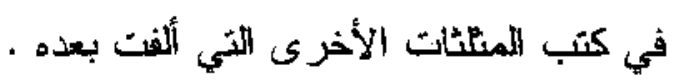

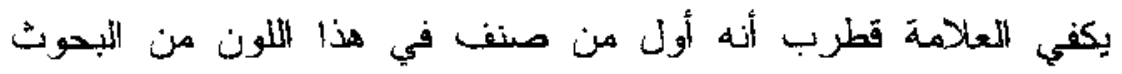

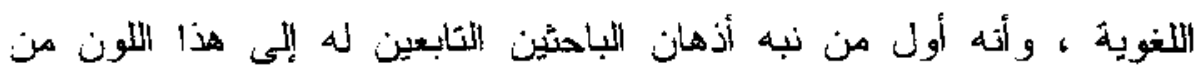

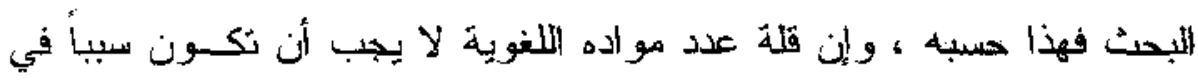

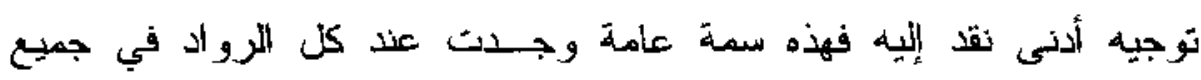

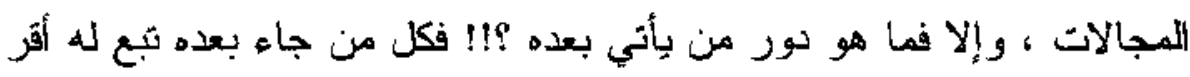
بذلك أم جحد ....

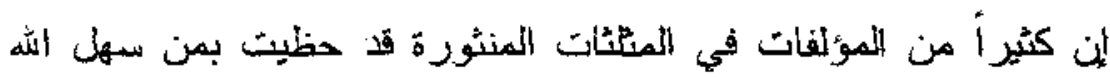

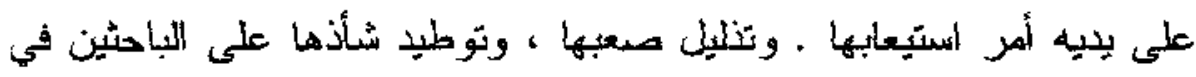

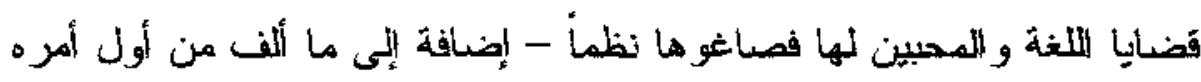

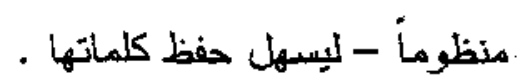

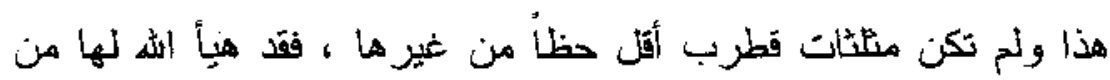

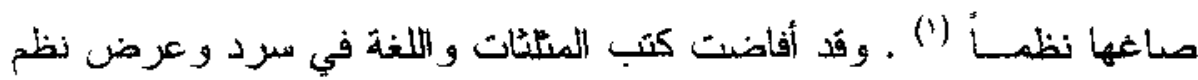

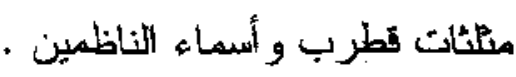

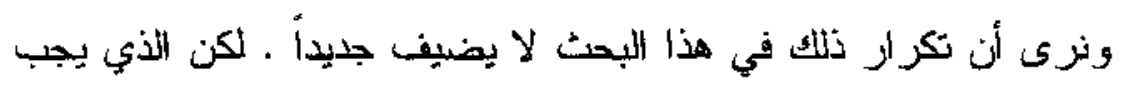

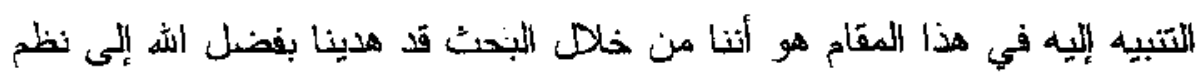

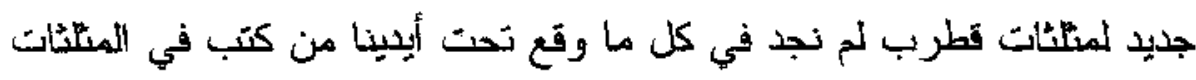

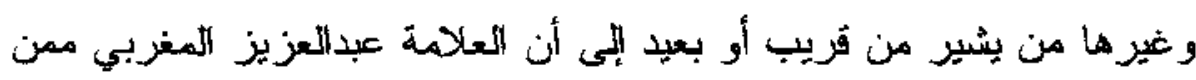

خلافأ لمن توهم فزعم أن تطرب تد نظمها ، وهو أمر مردود حيث لم يشبت بالدليل

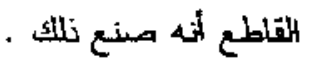




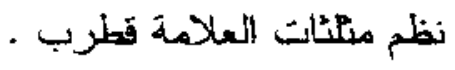

لهذا فإنتا نرى أن التتبيه إلى هذا ونشره في هذا البحت قد يكون فيه

فائدة و إضافة ، و إليكم هذا ألنظم :

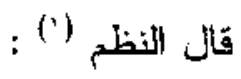

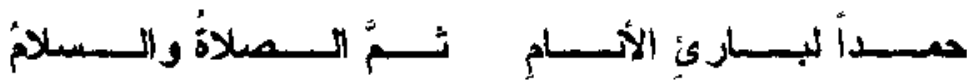

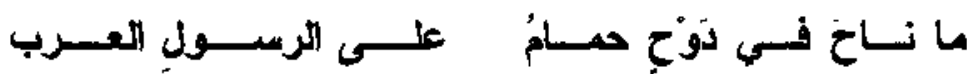

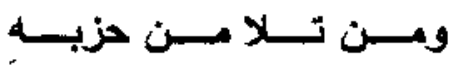

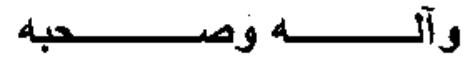

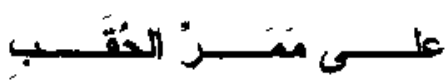

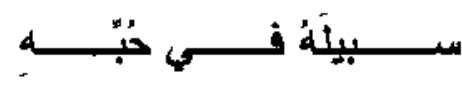

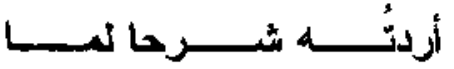
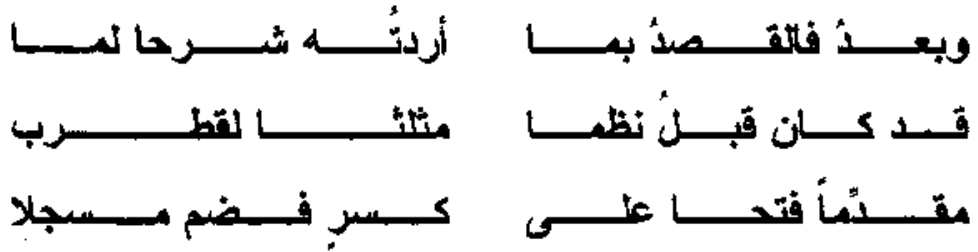

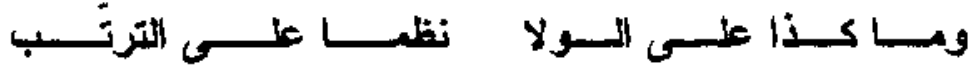

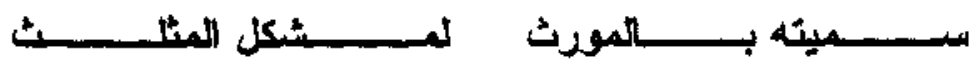

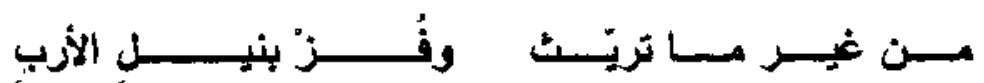

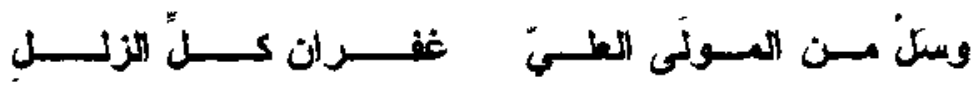

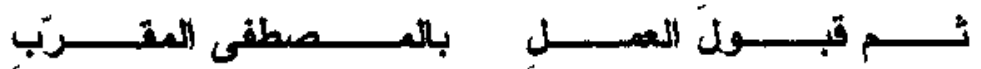

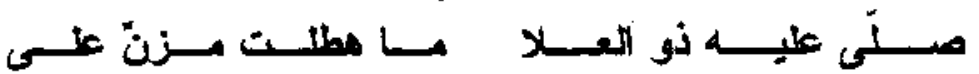

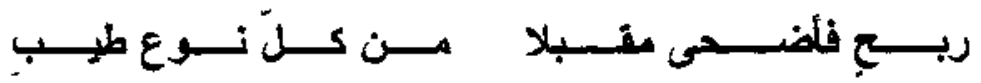

هو : العلامة عبدالعزيز المغربي في المجموع الكبير من المتون فيما يذكر من

$$
\text { الفنون صن : المهلها }
$$




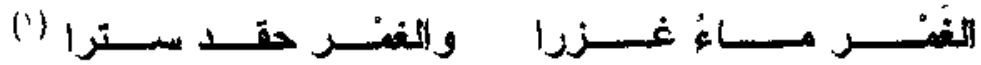

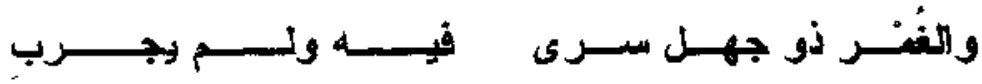

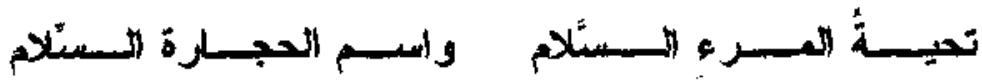

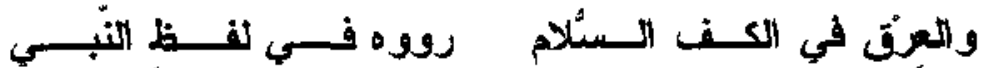

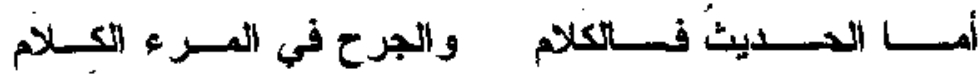

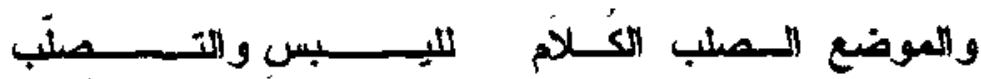

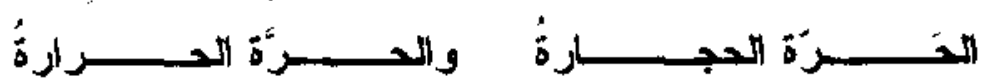

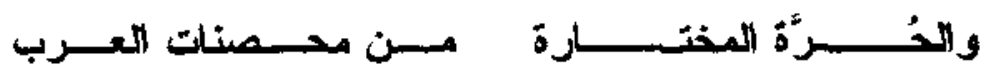

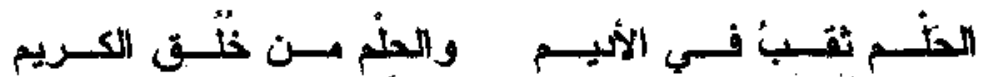

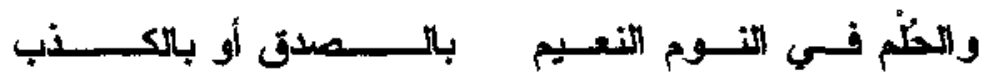

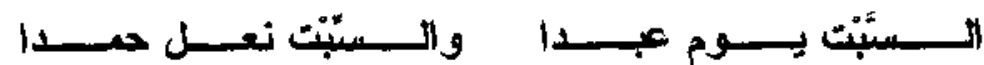

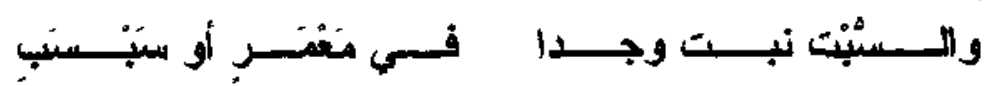

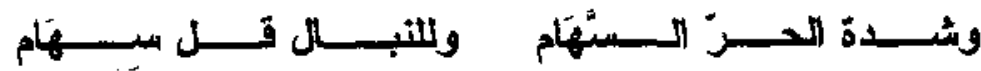

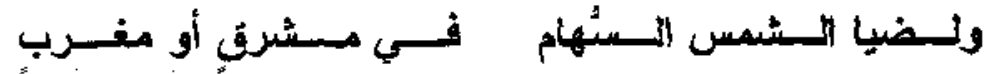

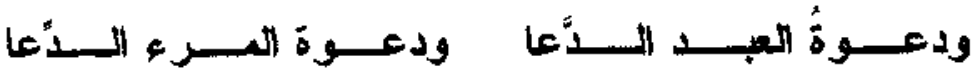

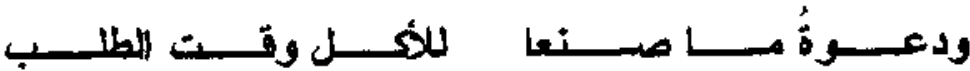

ومن هذا اليبيث بِدأ الناظم في ذكر الكلمات المثلثة حيث بدأ هذا بذكر كلمة الثغر فكررها ثلاثث مرأت ورضع إزاء كل كلمة معناها ـ ومنهجه في تزتيب الكلمة

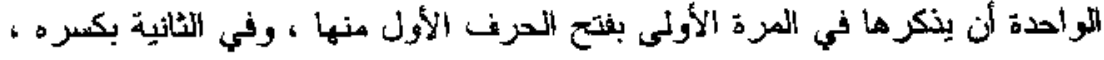

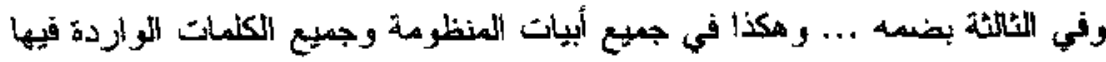




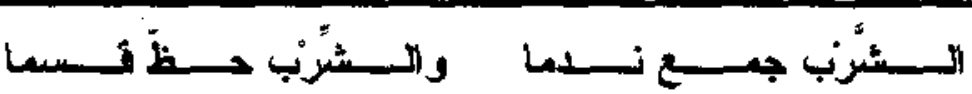

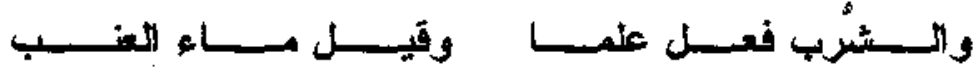

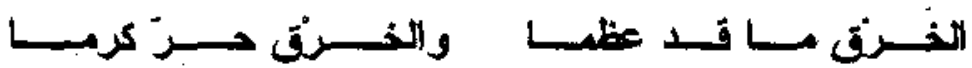

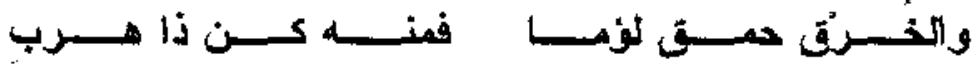

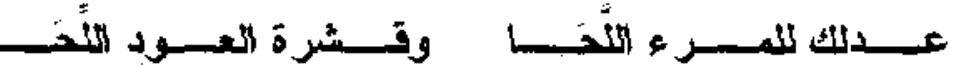

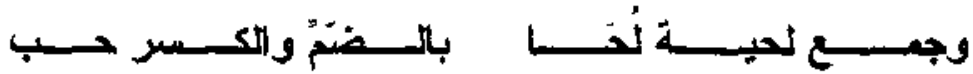

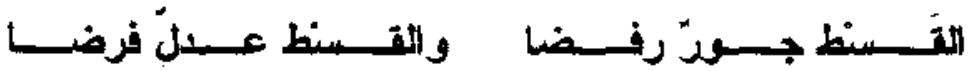

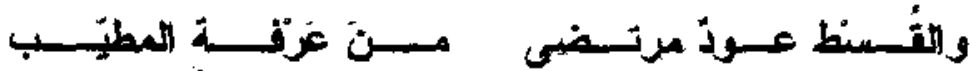

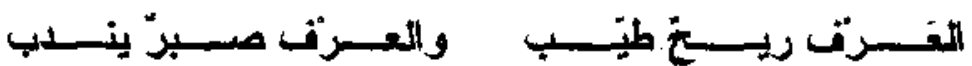

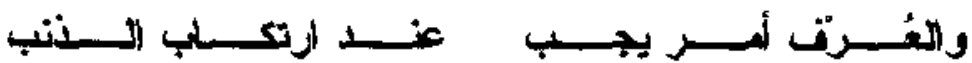

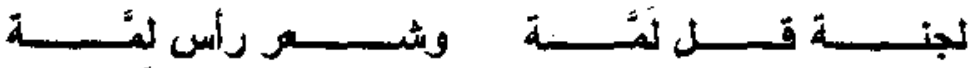

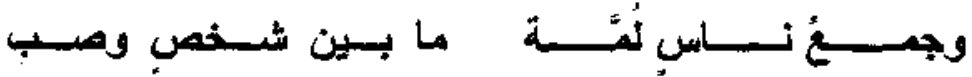

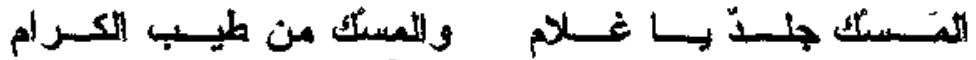

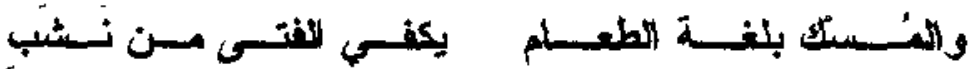

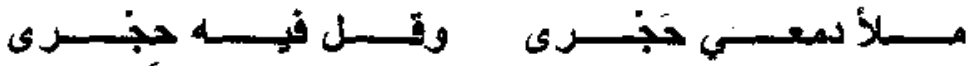

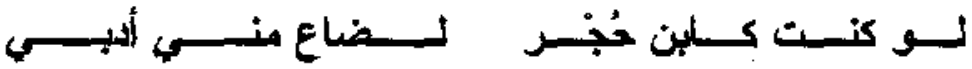

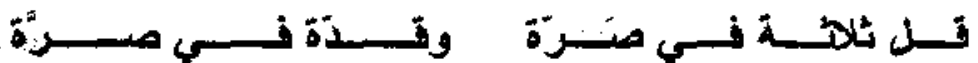

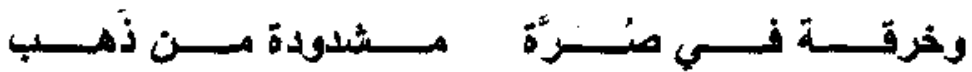

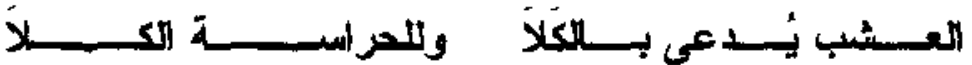

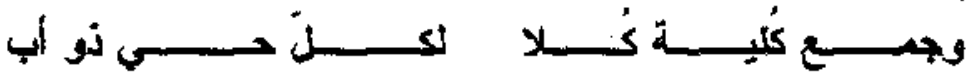

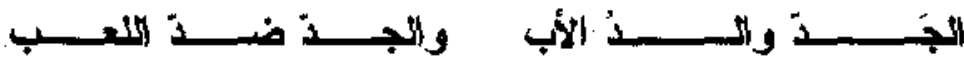




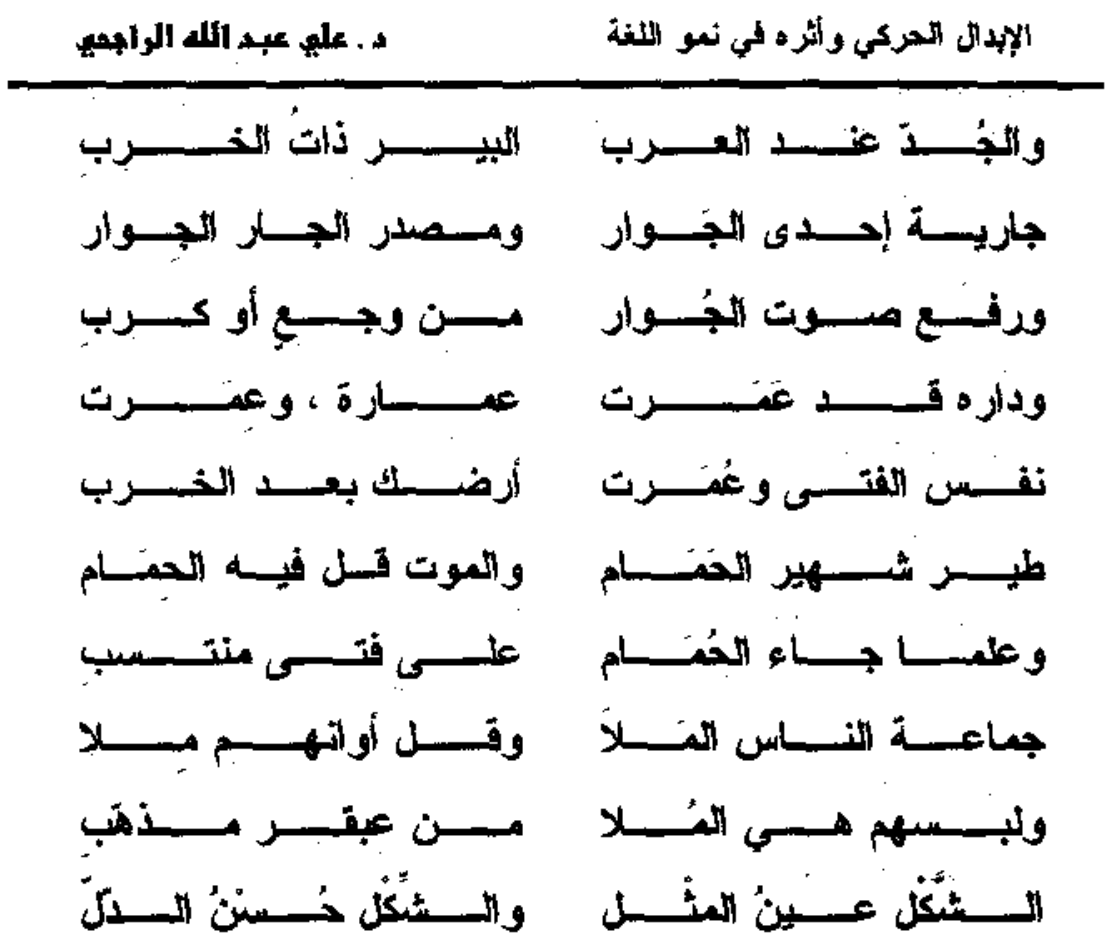

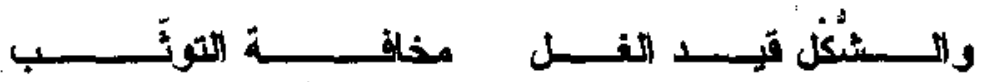

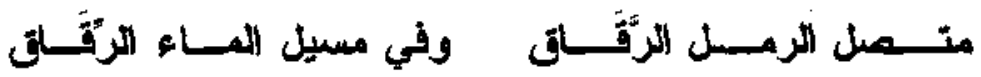

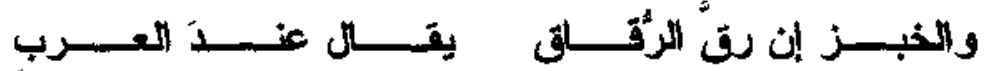

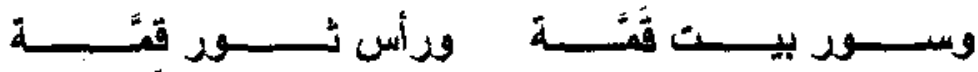

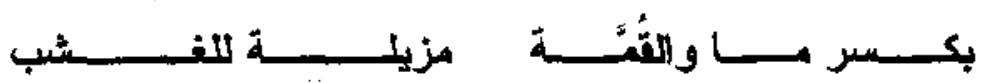

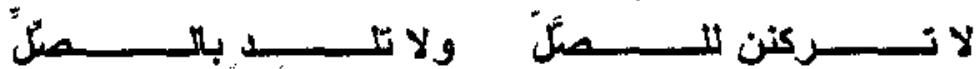

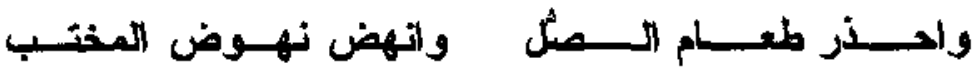

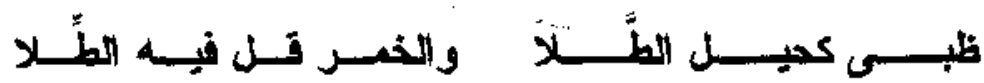

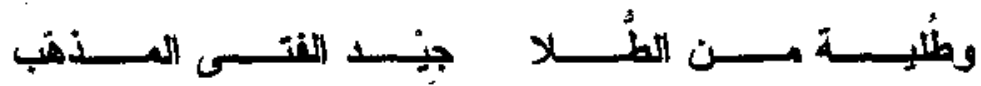

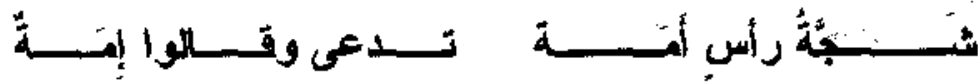

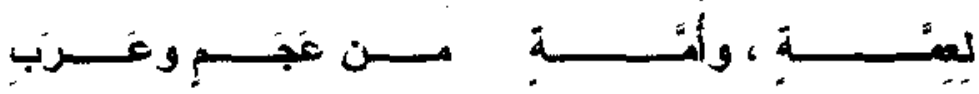




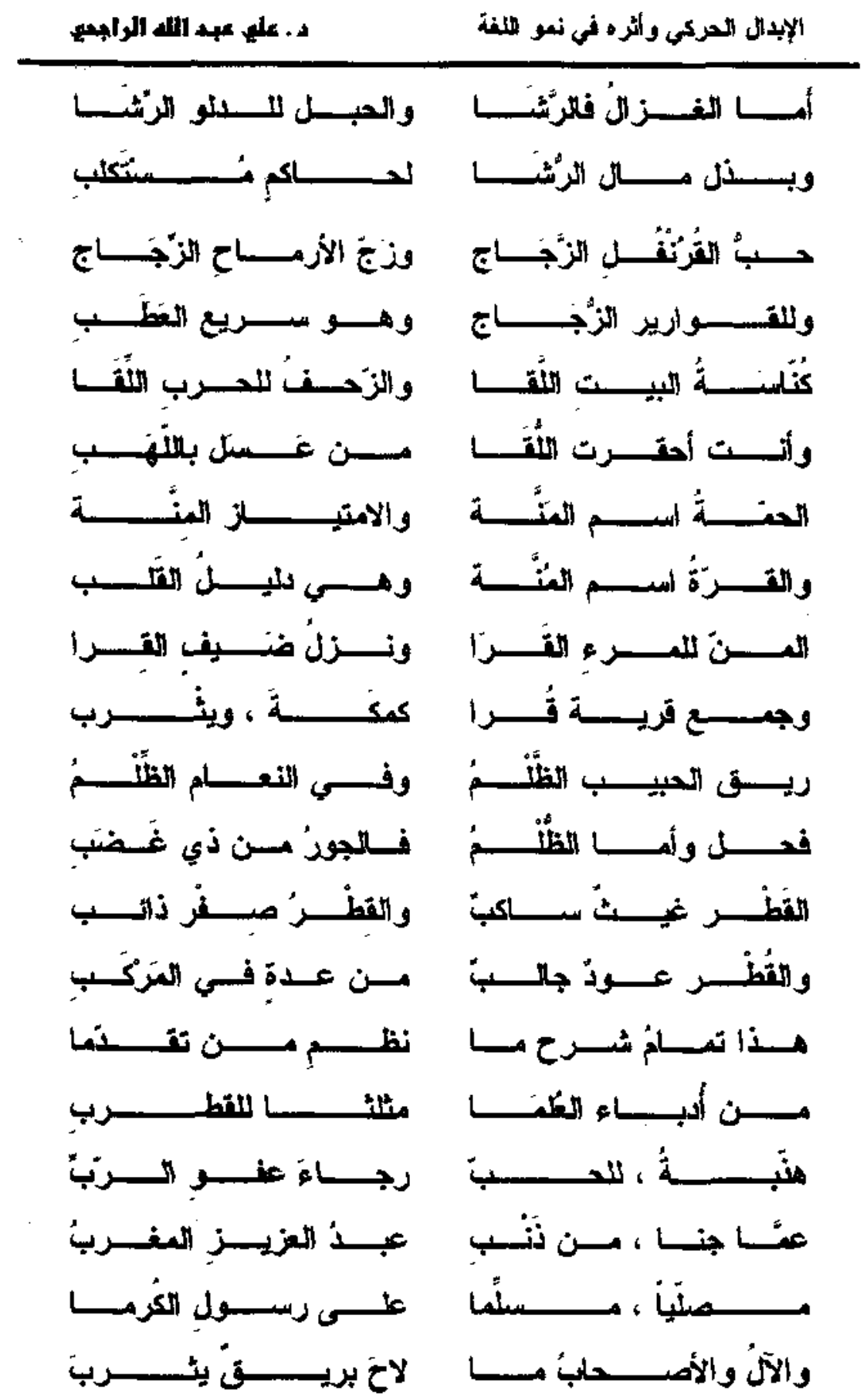




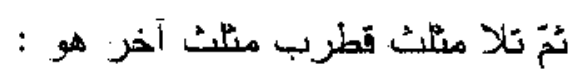

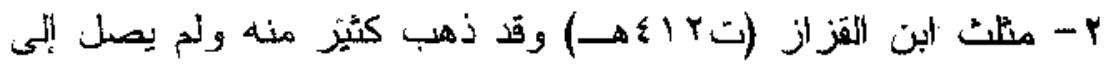

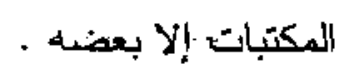

وقد أحتوى الجزء المتنقى من المخطوط على الثنتين وبشرين ومائتي

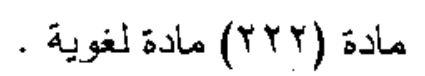

وتجدر الإحاطة أيضاً إلى أن صاحبه قد اقتصر على المثلث المختف مأف

· المعنى

ع- هيثت ابن السيد (ت ابهــ) ، وهو ثالث الكتب التي وصلت إلى

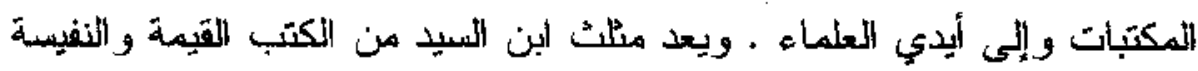

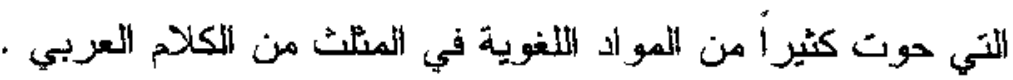

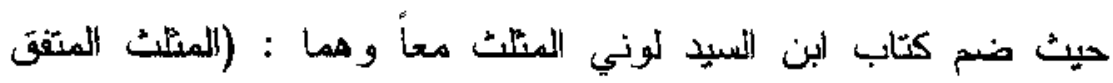

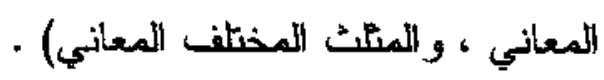

فقد جمع في كتابه هذا من المثتث المثفق المعاتي مائة وبثمان وبثلاثين

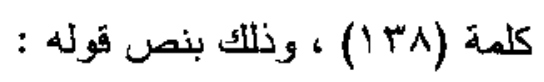

"فاجتمع لنا .... ومن المثلثد المتفق المعاني مائة كلمة ونمان ونثلاثون

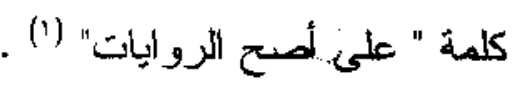

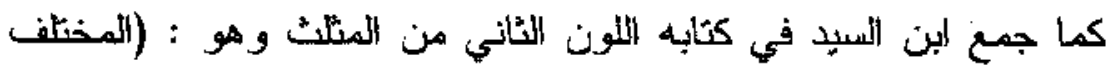

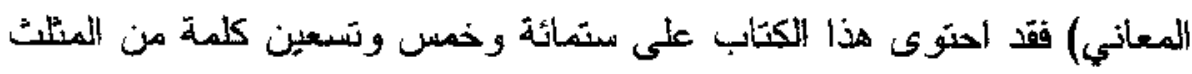

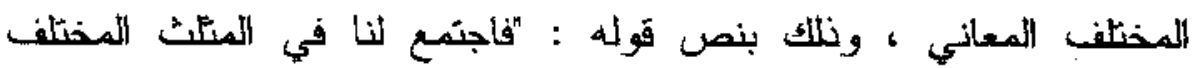

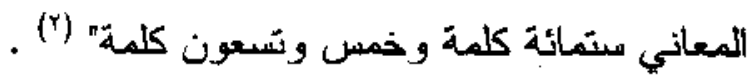

$$
\begin{aligned}
& \text { ينظر مثتث اين السيد /99// . }
\end{aligned}
$$

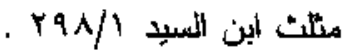


ومما تجلر الإشارة إليه أن الفرق بين العددين المذكورين في لوني

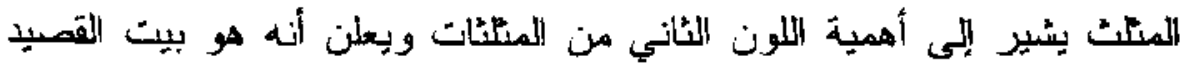

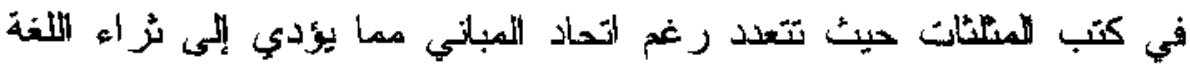

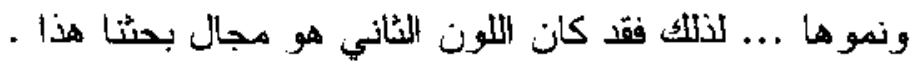

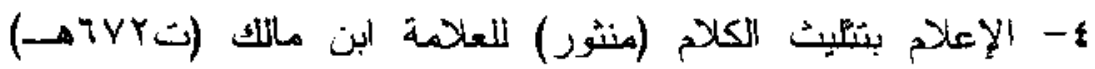
و عدد كلماته على النحو التالّي : . (T9V)

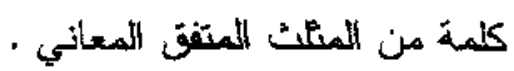

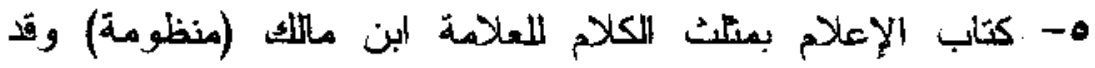

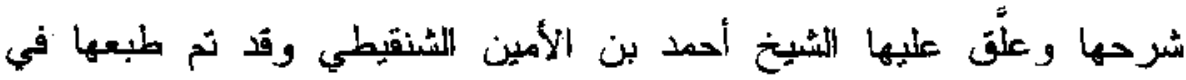

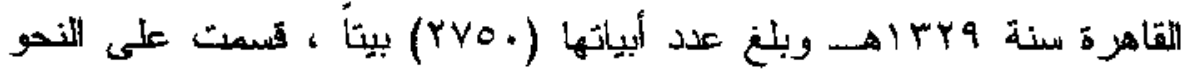

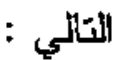

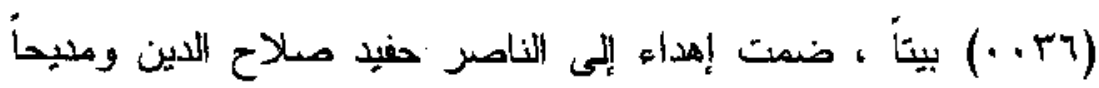

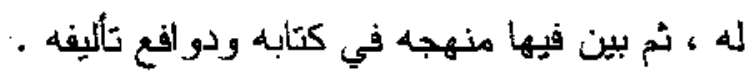

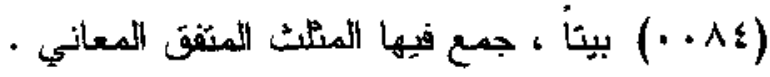

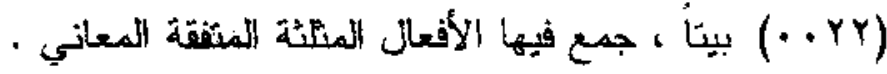

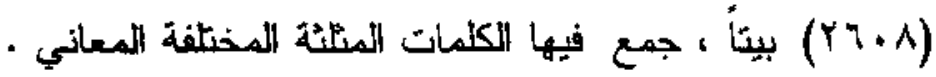

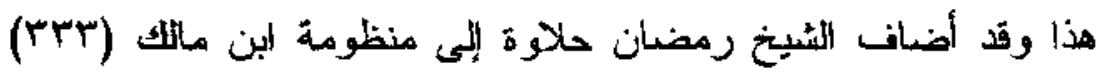

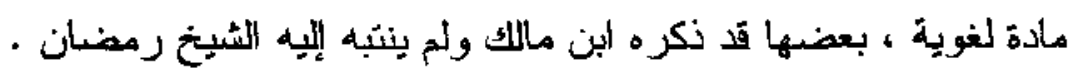

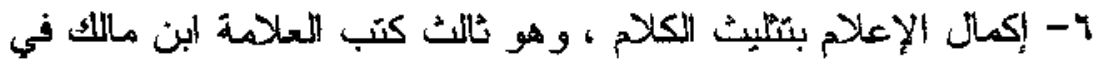

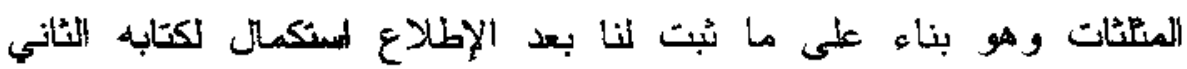


يؤكد ذلك أن كتابه الأول (المنتور) محدود الكلمات وأن صاحبه لم يصل فيه الميلى النضهج الفني ، و العلمي الكاملنين .

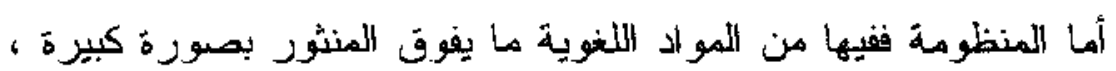

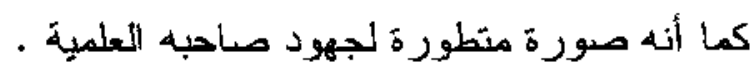

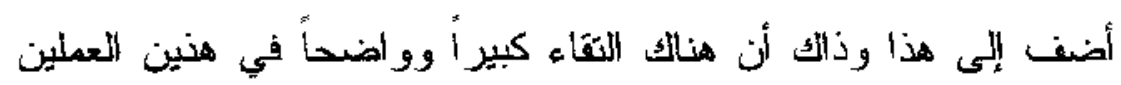

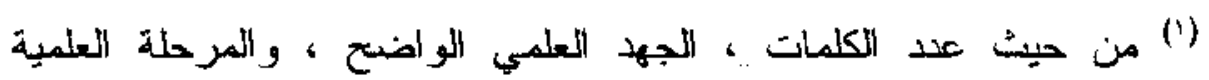

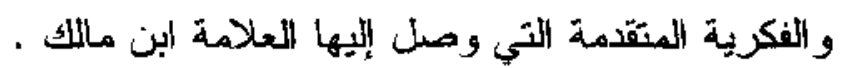

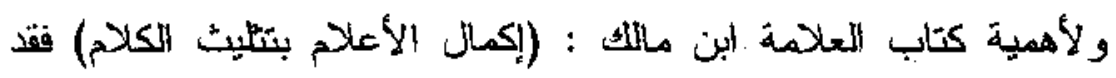

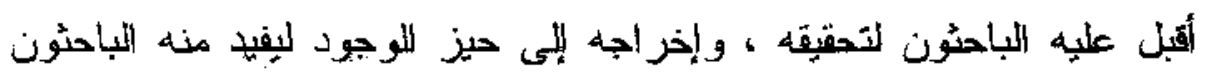
والأرسون).

إن كتاب العلامة ابن ماتلك الذي نحن بصدد الحديث عنه قد تم تحقيقه

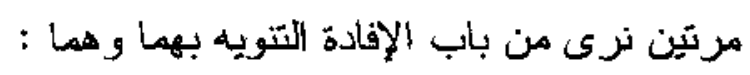

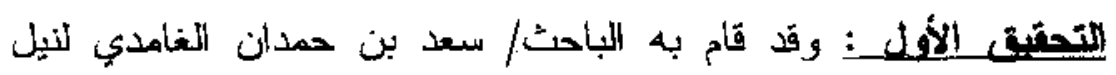

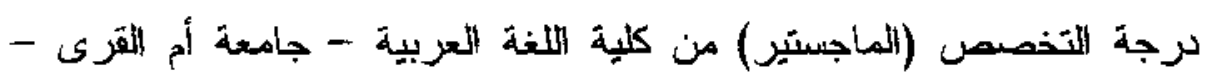

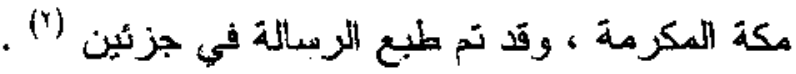

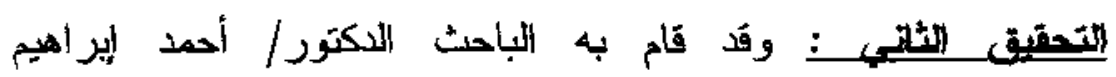

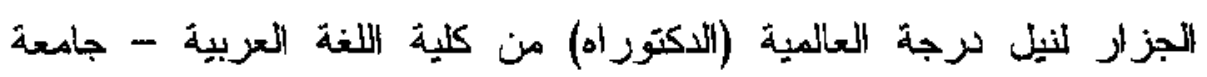

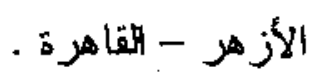

وهما : كتلب الأعلام بمثن الكلام (منظومة) للعلامة ابن مالك ، إكمال الأعلام

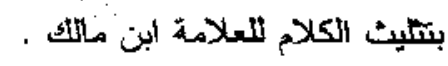

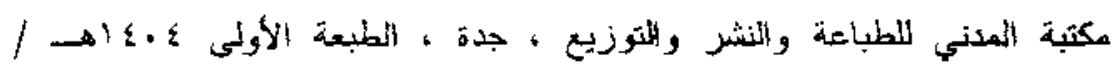




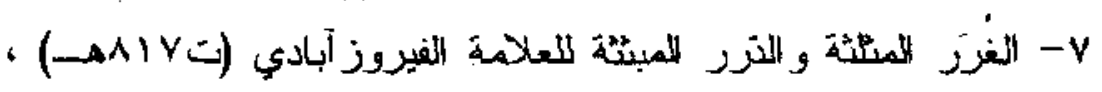

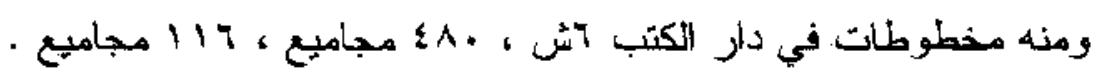

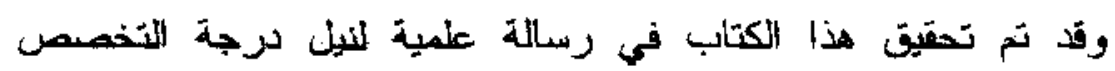

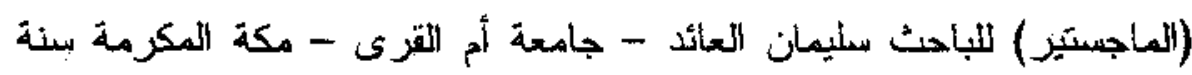
A A

$$
\text { فهذه أشهر المؤلفات في المندث قديماً . }
$$

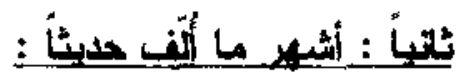

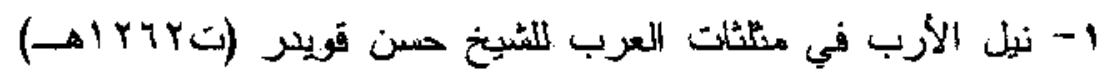

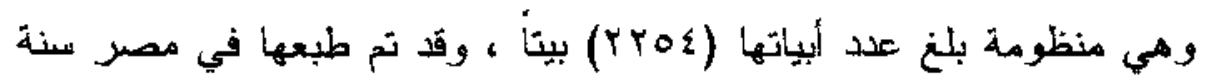

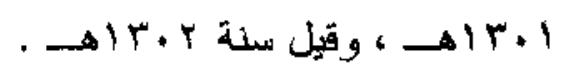

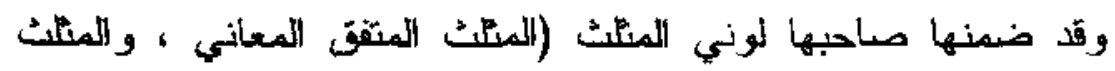

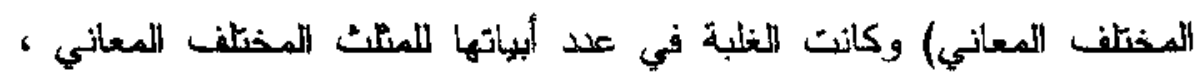

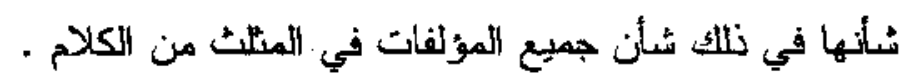

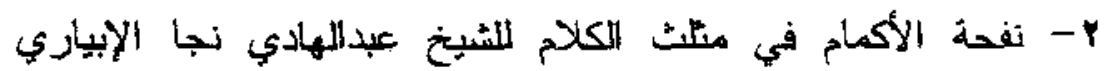

$$
\text { (ت) }
$$

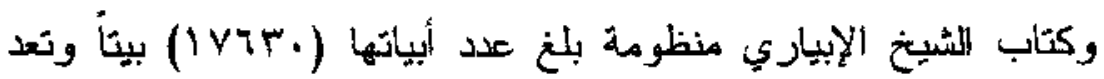

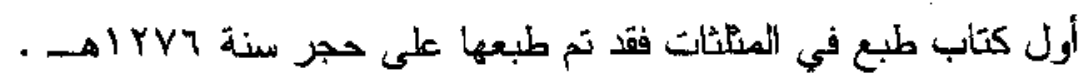

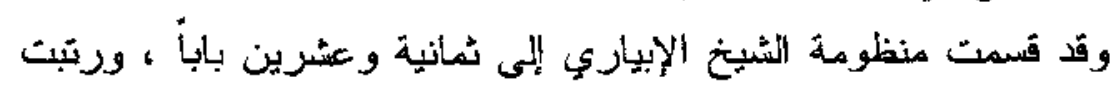
على حروف المعجم ، بجعل كل حرن من حروف الهجاء باباً .

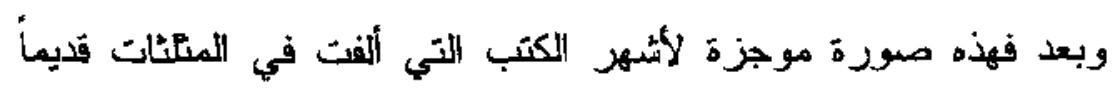

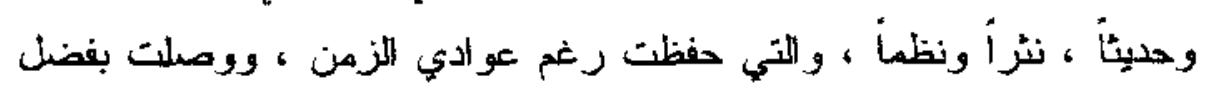

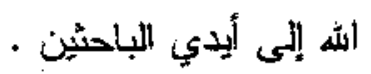
وفرق هذا وذالك فإن معاجمنا العربية - حفظها الثه - قد وخحت أمر 
هذه الكلمات المبندة أثناء شرحها لهذه الألفاظ .

و هذا ويطيب لنا في هذا المقام وبعد هذا العرض الثدافي للمتث وكتبه

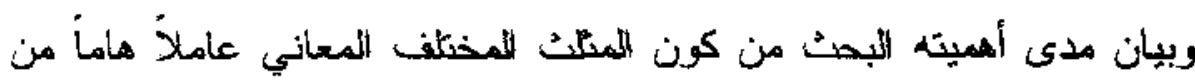

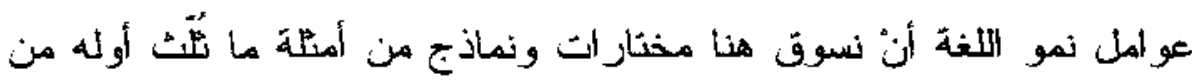

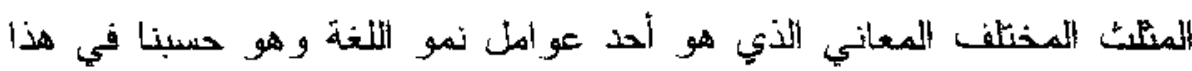
البحث نظرأ لضيق المساحة ، ود لالثته على غيره من أشباهيه.

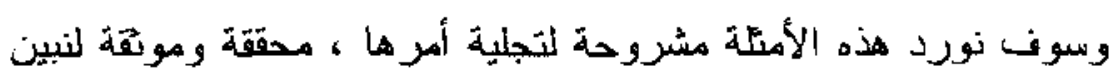

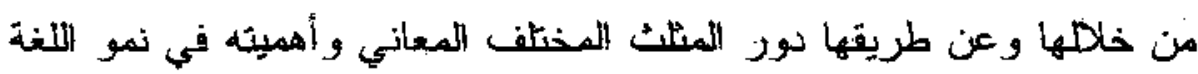

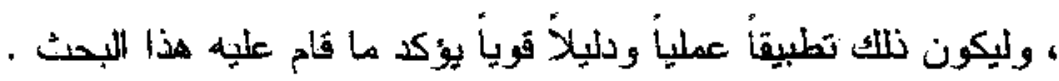

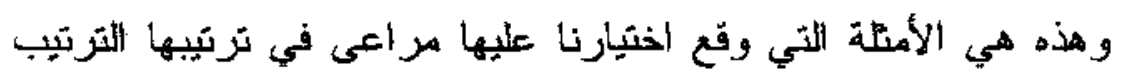

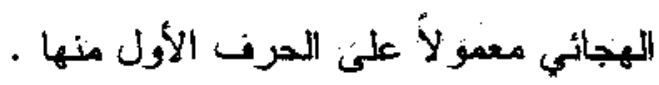

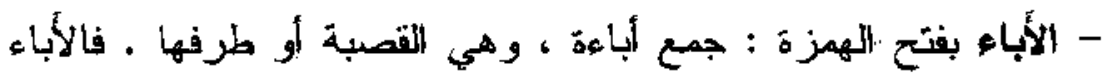

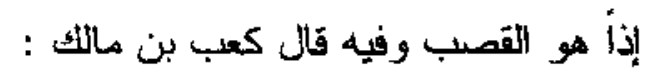

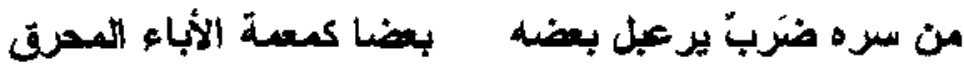

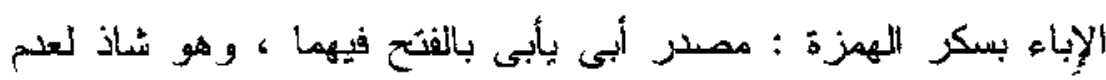

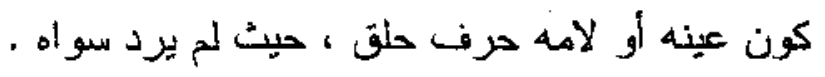

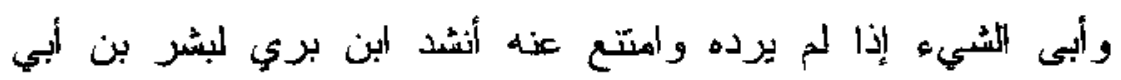

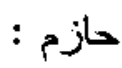

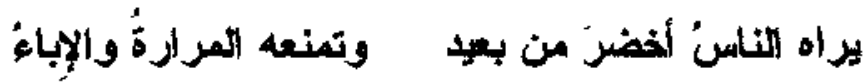

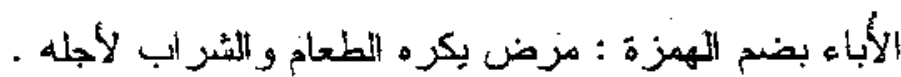

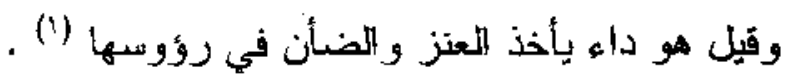

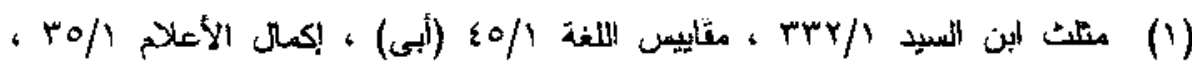
$-r \cdot$ 


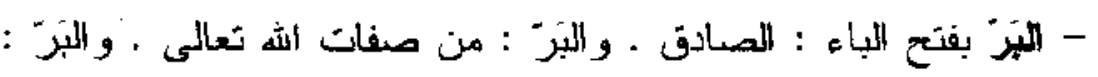

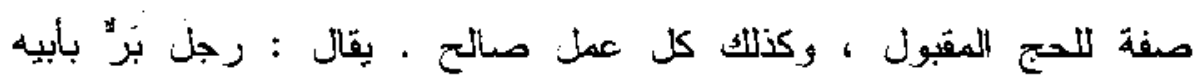

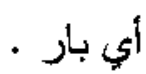

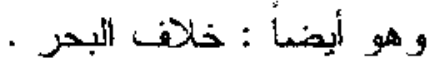
البِر" بكسر الباء : ضد العقوق · وقَيل : الإكرام · وقَيل : فعل كل خير

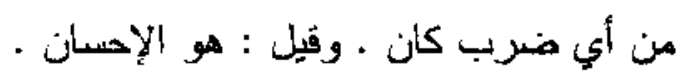

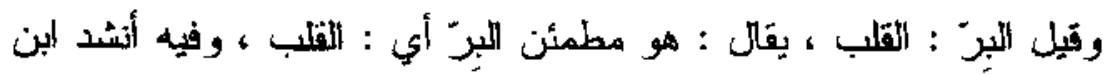

$$
\text { الأعر ابي: وكئ }
$$

أكون مكان "البِر" منه ودونه وأجعل مالمي دونه وأونامره

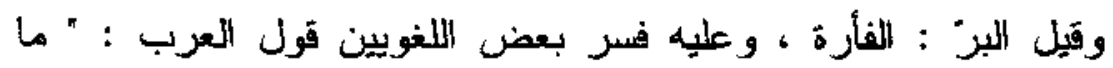

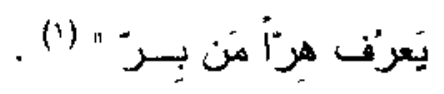

البُرّ" بضم اللباء : الخنطة ، قال المهنلي :

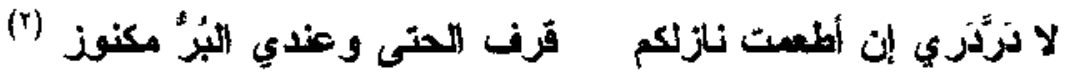

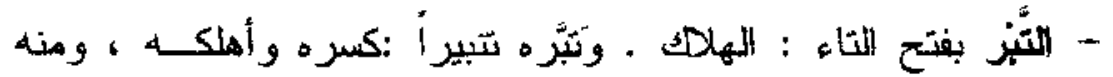

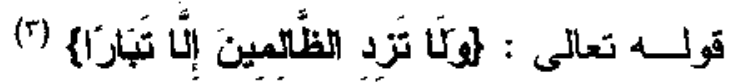

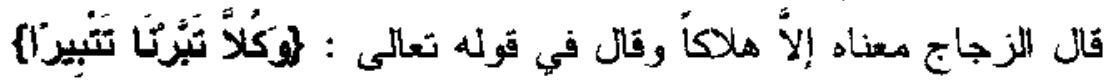

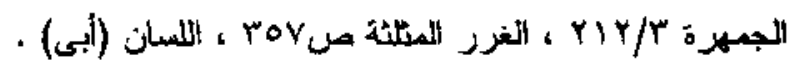

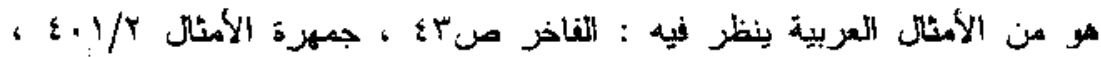

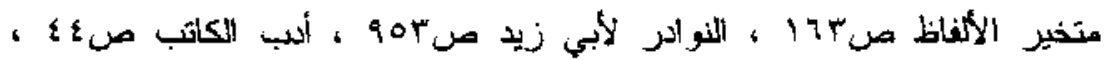

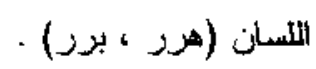

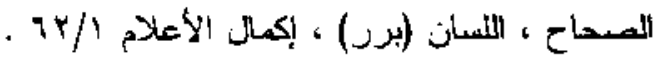

$$
\begin{aligned}
& \text { نو : (1) }
\end{aligned}
$$


· التنبير : (1)

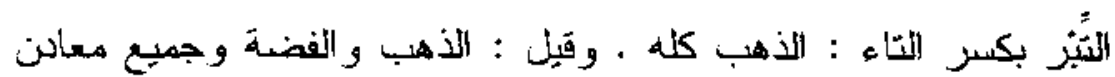

الأرض وأكثر اخنصاصه بالذهب .

وقيل : هو الذهب و الفضة قبل أن يصاغا ، فإذا صيغا فهما ذهب

وفضة .

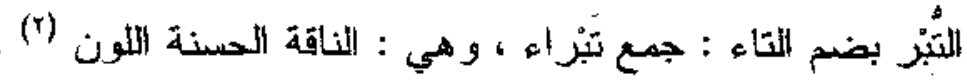

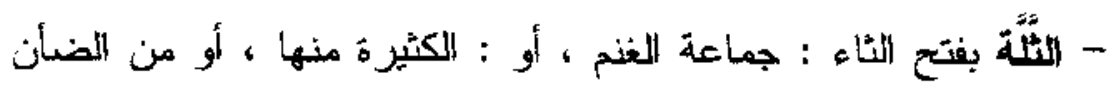

خاصة.

ولذا فقد قيل : " و لا يقال للمعزى الكثيرة ثتَّة إلا أن بخالطها الضضأن .

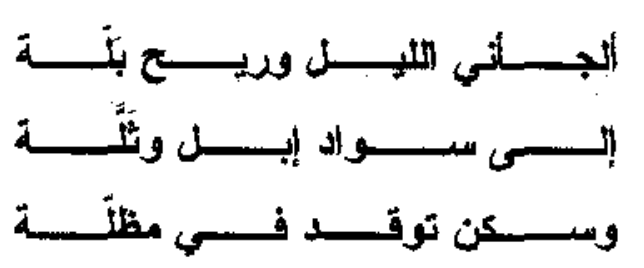

قال التر اجز : قاجز

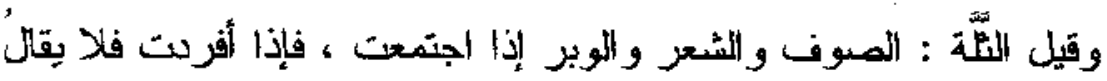

نها ثهانة

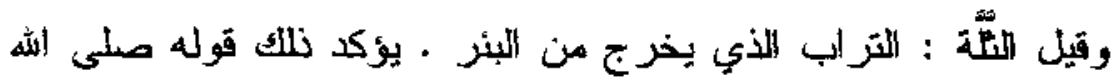

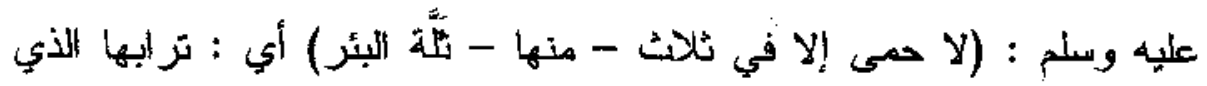

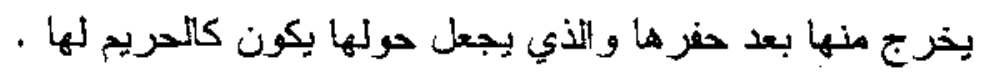

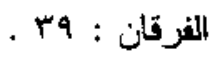

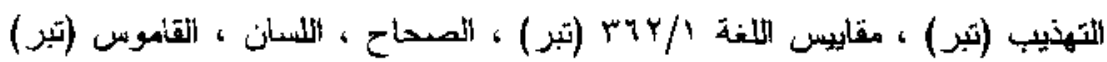

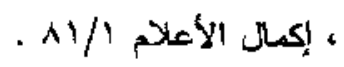




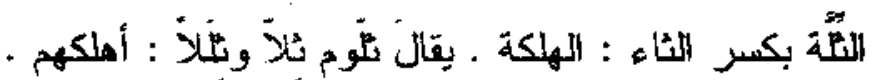

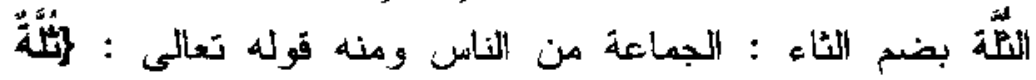

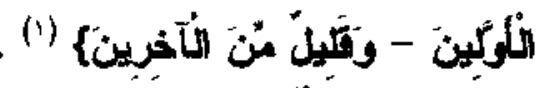

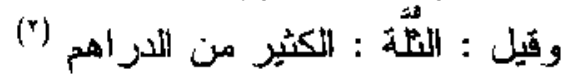

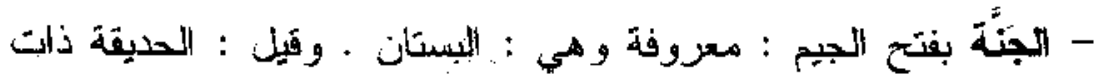

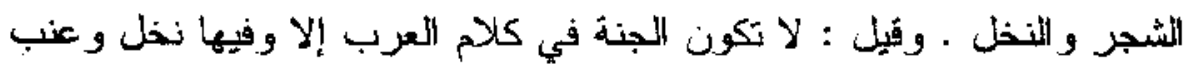

، وإلا فهي حيقة .

يؤكد ذلك ما ورد في القرآن الكريم ، فقد ورد تفسير الجنة في غير

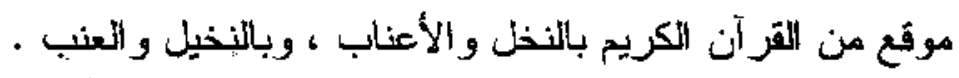

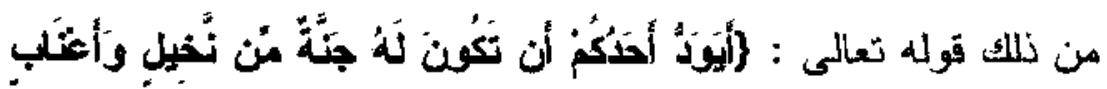

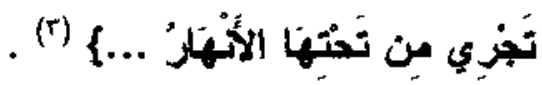

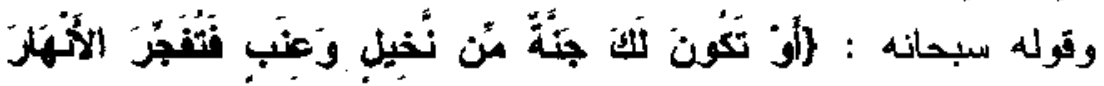

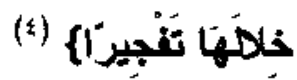

والجنة هي : دار النعيم في الدار الآخرة - جعلنا الشه وإياكم من أهلها

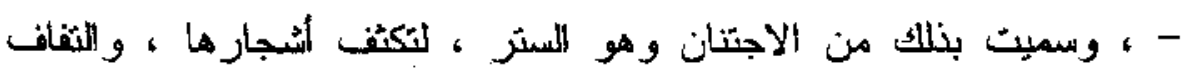

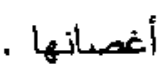

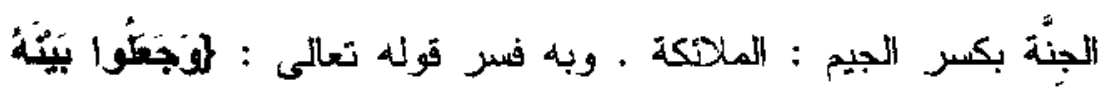

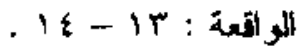

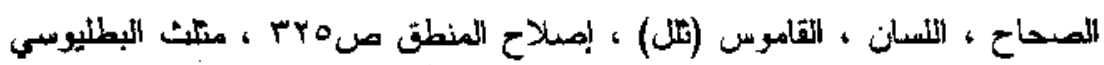

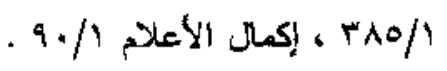

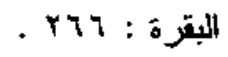

9) : الإسر : (4) 


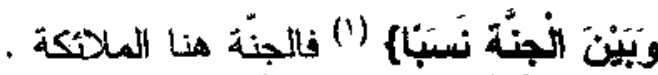

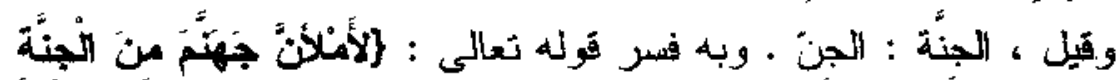

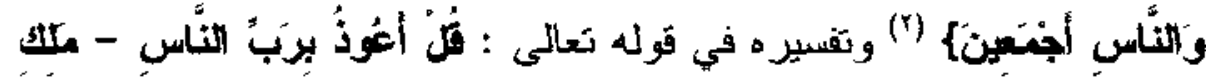

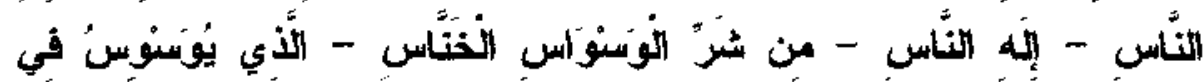

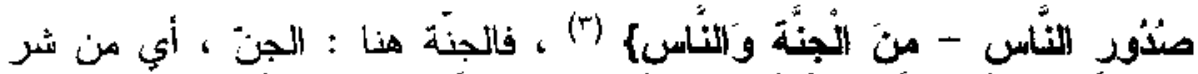

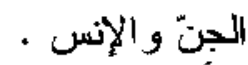

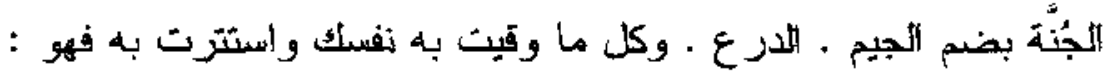

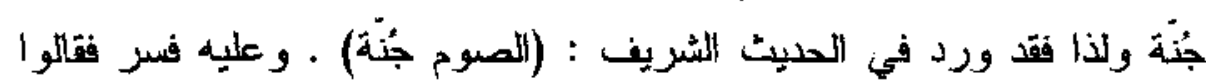

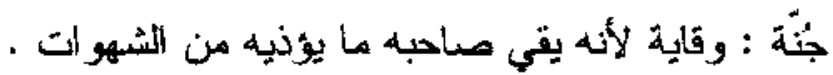

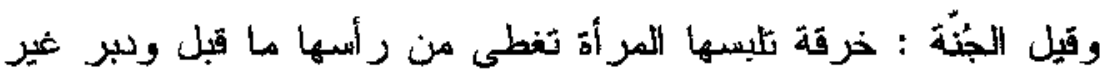

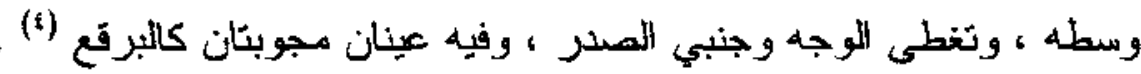

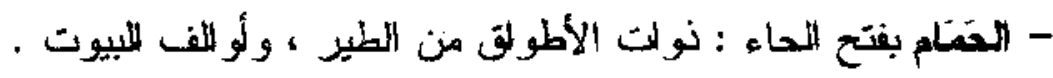

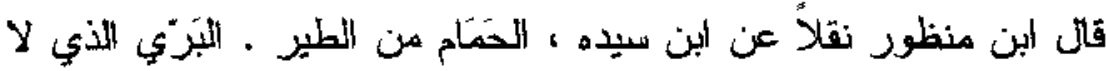

$$
\text { يألف اللبيوت ، ورذه الثي تكون في الليوت هي : }
$$

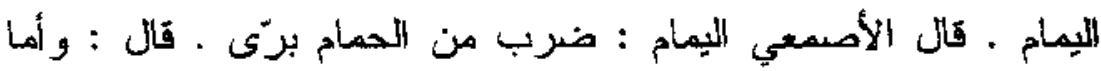

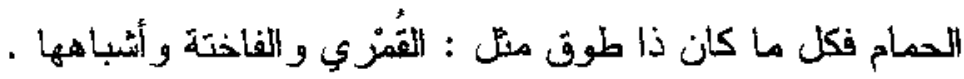

$$
\begin{aligned}
& \text { المافات : 101 . } \\
& \text { هود : 119 ، السجدة : rأ ـ }
\end{aligned}
$$

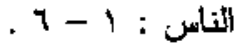

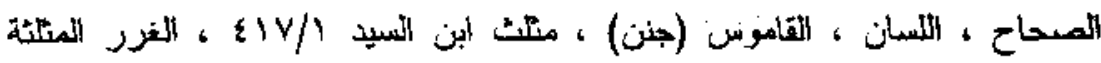

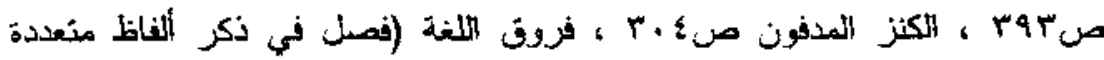

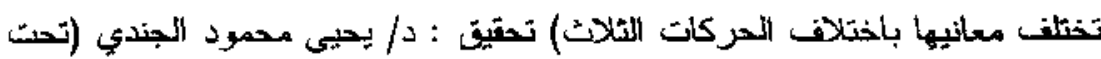




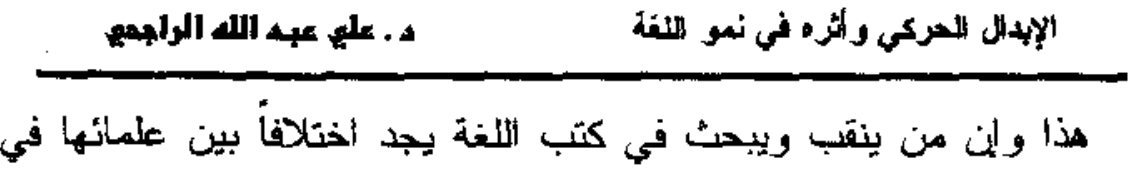

شرح وتفسير ألفاظ اللغية ، وقد اختلف الأصمعي و الكسائي في شرح وتنفسير كلمة

(الحُمام) - بفتح الحاء- و التي نحن بصدد شُرحها حيث بصر الأمسعي على أن ما يسكن اللبيوث ويألفها هو : الحمام · والبري هو : الليمأم · والكسئي

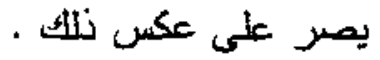

والأرنى أن نقول مع القائلمين : إن التحمأم هو ذوات الأطولت من الطبر حيث قال بذلك معظم علماء اللغة منهم : العلامة الجوهري الذي قال : والحمام عند العرب : ذوات الأطو اق من نحو الفو اخث و القماريي . الحمام بكسر الحاء : الموت ، وقيل : قُخاء الموت وعدره وهو هن

$$
\begin{aligned}
& \text { قولهم : حم كذا أبي قدر ، ومنه قول ابن رواحة في غزوة مؤتة : }
\end{aligned}
$$

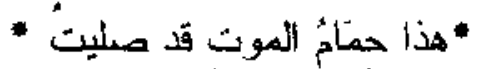

الاحُمَام بضم الإحاء حمّى الإبل و الدواب . روى الأزهري عن ائن شميل

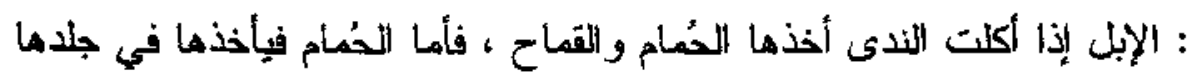
حر حتى يطلى جسدها بالطنين .

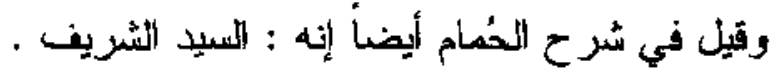

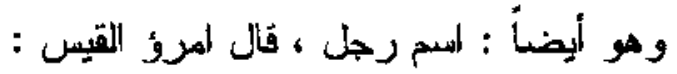

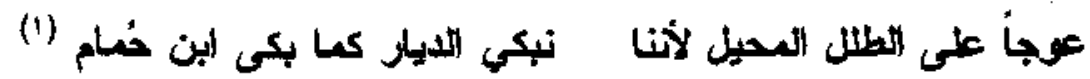

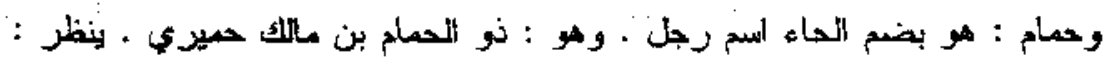

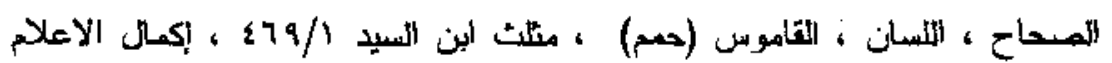




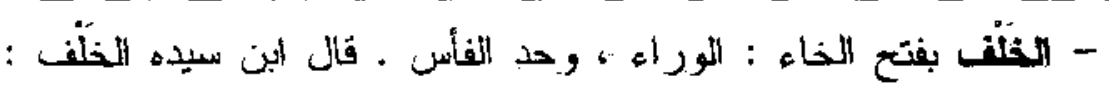

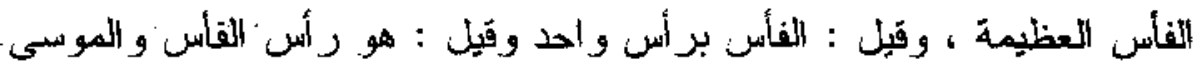

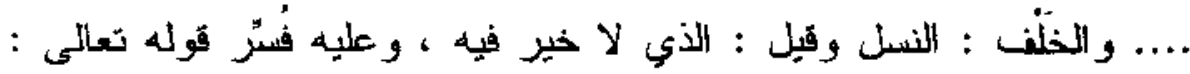

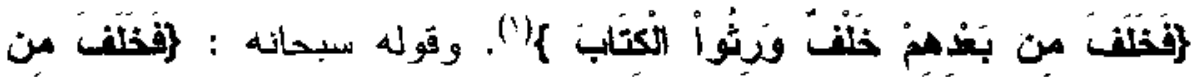

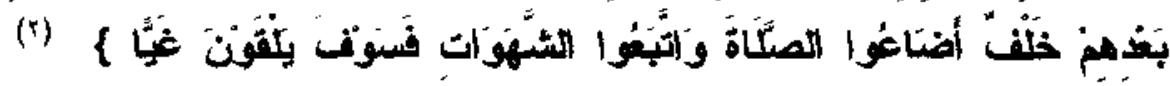

$$
\text { وحمل عليه قول لبيد بن ربيعة العامري : }
$$

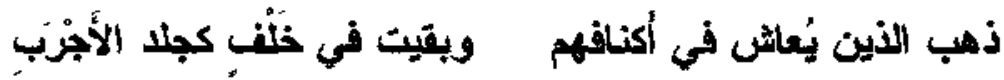

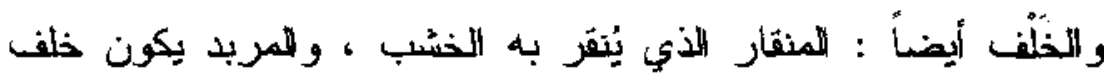

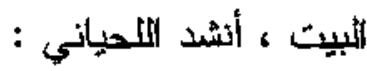

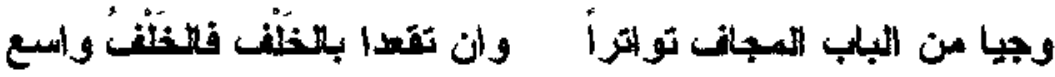

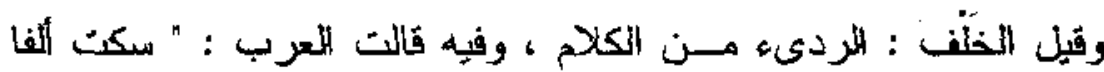

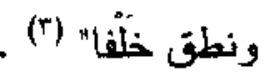

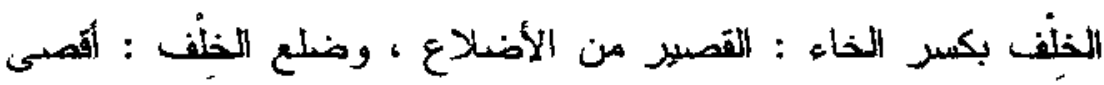

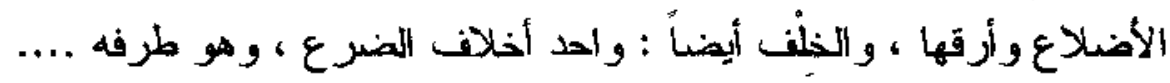

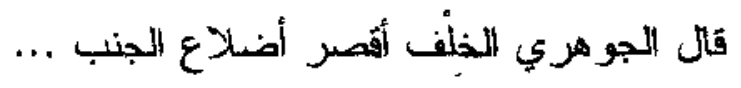

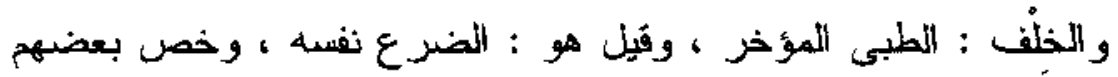

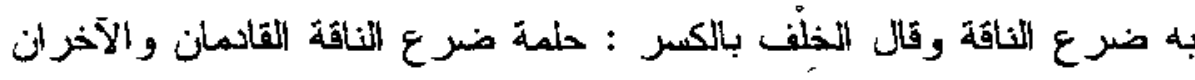

$$
\begin{array}{r}
179 / \omega \\
.09 / 1
\end{array}
$$

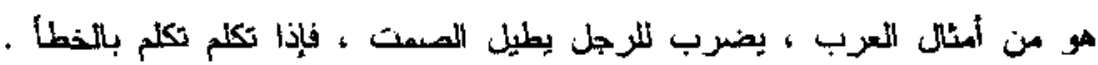

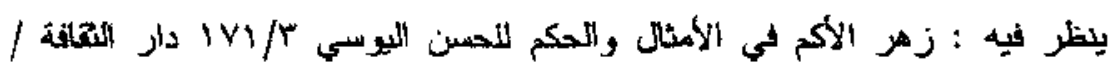

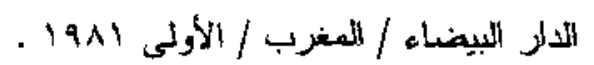




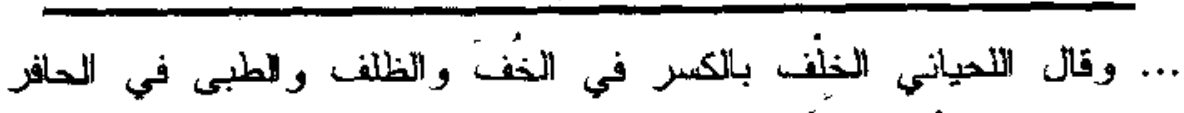

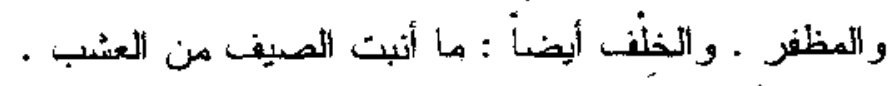

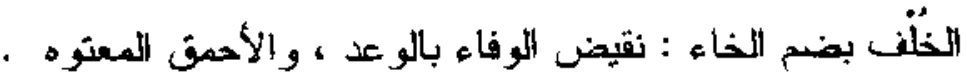

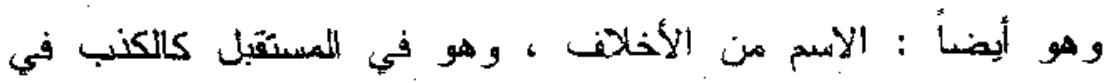

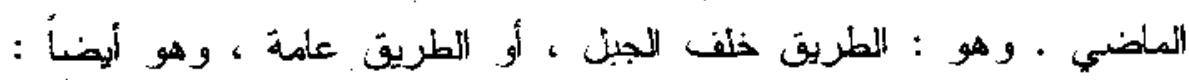
(")

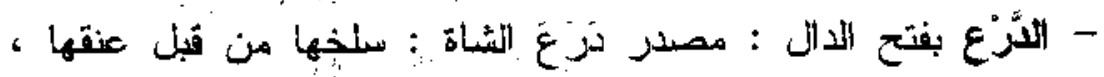

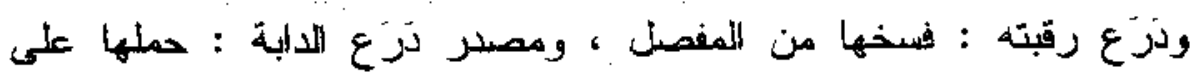

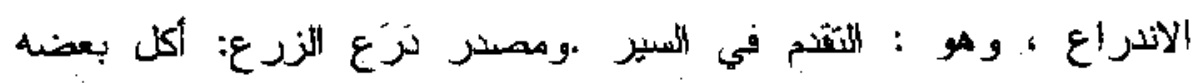

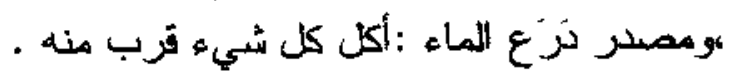

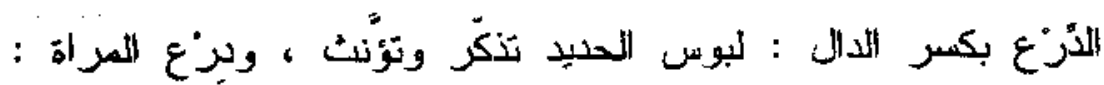
قميصها ، وهو مذكر فقد عند اللحياني ، وإين قال غيره فيه بالتنكيز والتأنيث

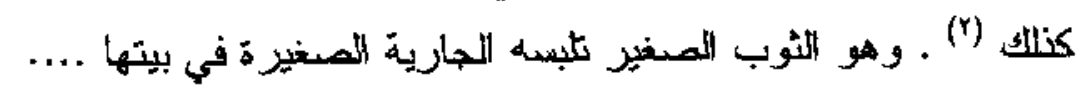

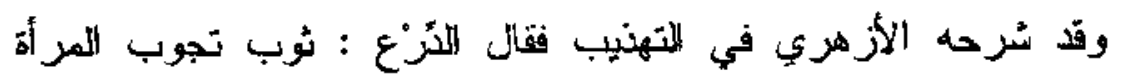
وسطه ، وتجعل لله يدين ، وتخيط فرجيه .

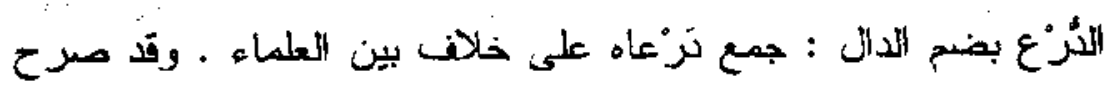

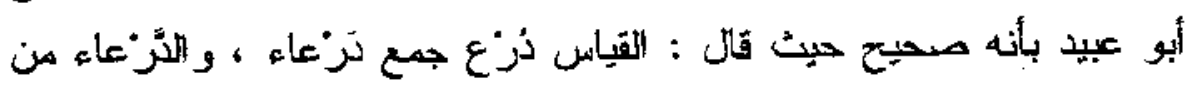

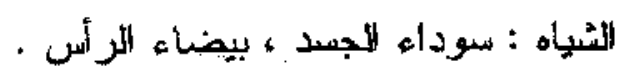

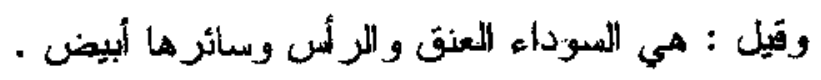

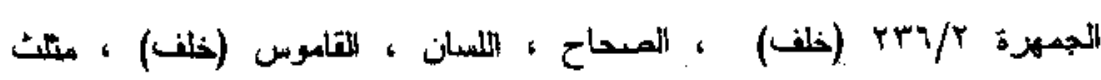

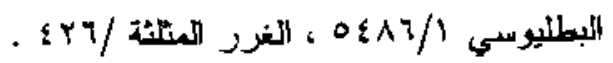

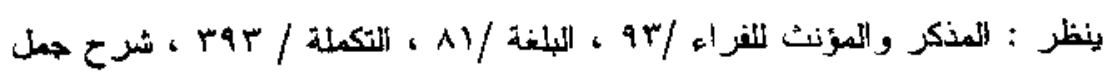

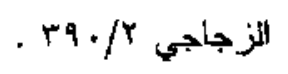




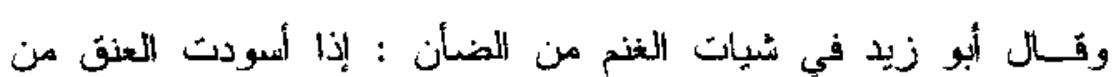

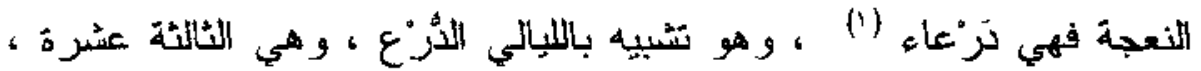

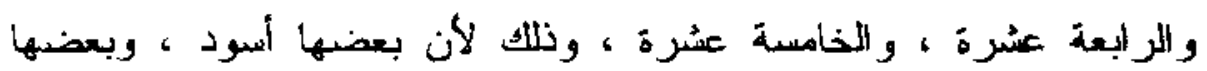

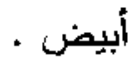
وقيل : هي الثي يطلع الثقر فيها عند وجه التصبح ، وسائر ها أسود

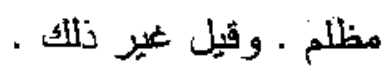

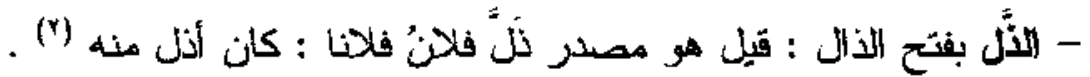

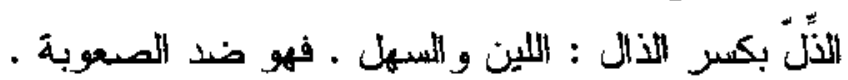

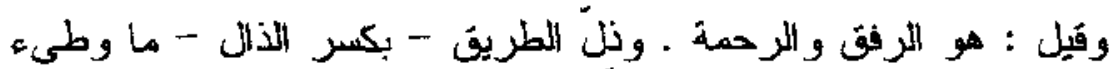

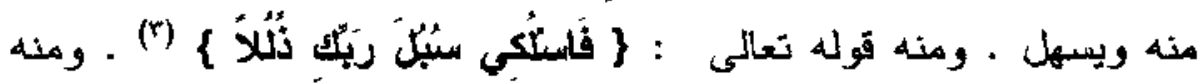

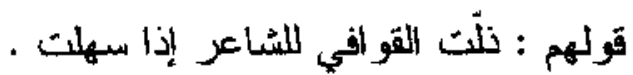

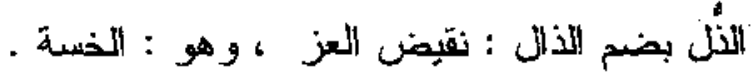

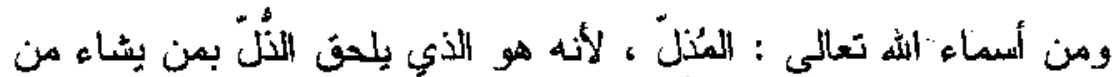

هكذا نكر ابن منظور في لسانه (درع) وهو ليس نص ما تاله أبو زيد لان النصر.

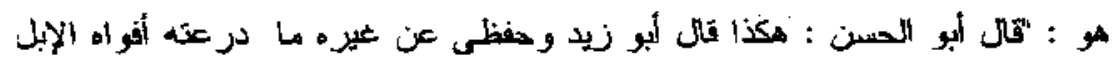

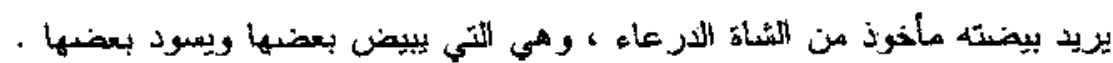

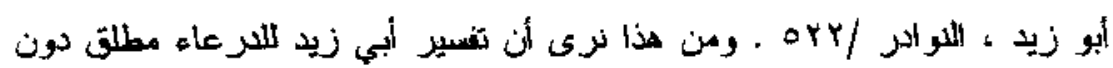

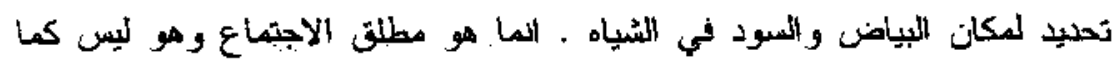
ذكر ماحب اللسان .

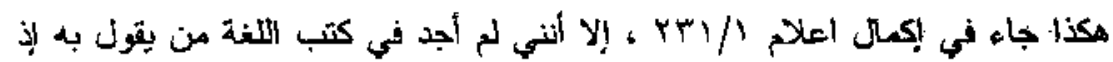

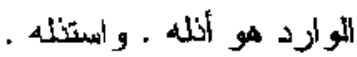




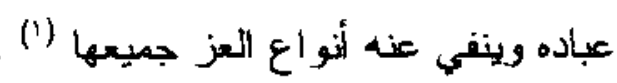

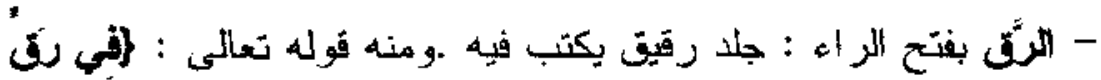

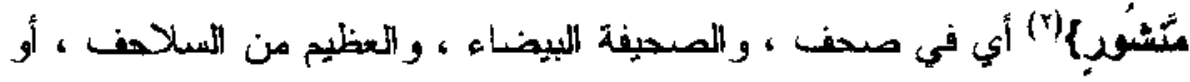
دويبة مائية .

وقيل : ضرب من دواب الماء شبه لنمساح · وفي الحديث :"كان فقهاء

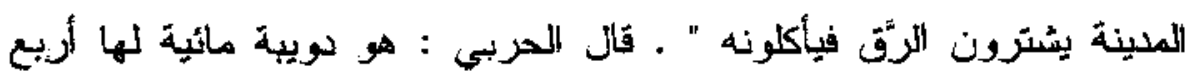

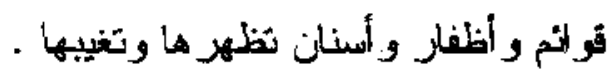

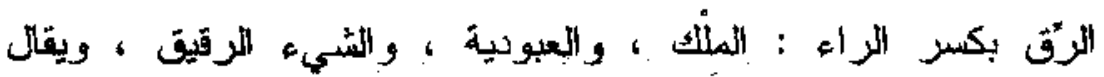

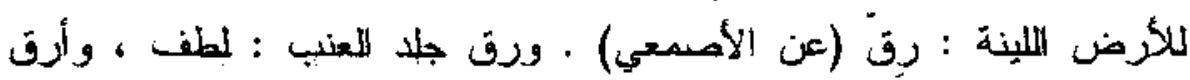

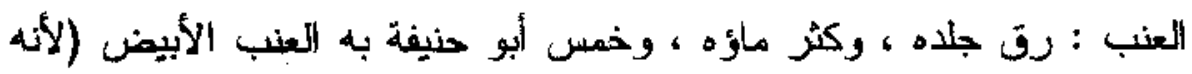

$$
\begin{aligned}
& \text { يشف عن ذلك ) . }
\end{aligned}
$$

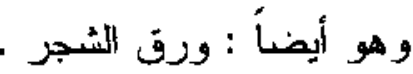

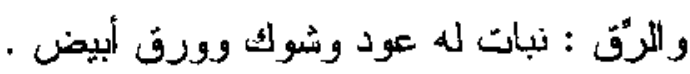

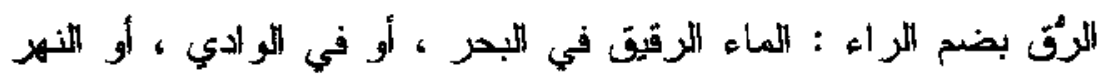

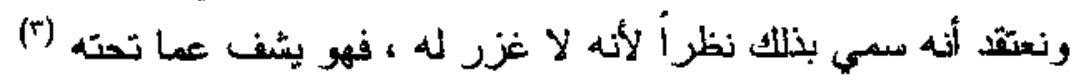

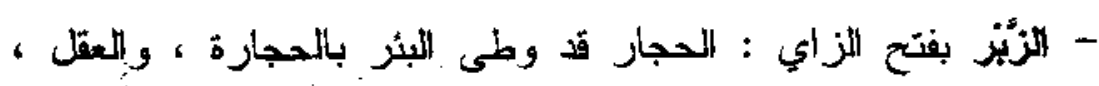
والمرأي .

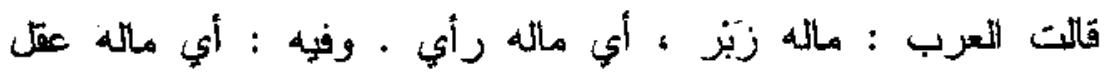

وتماسطك (i)

$$
\begin{aligned}
& \text { المحاح • بللسأن ، القاموس (ذلتك) • إكمل الاعلام } \\
& \text { الطور / r r }
\end{aligned}
$$

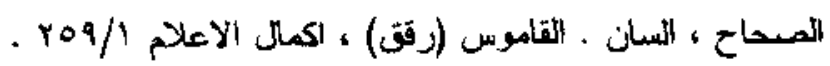

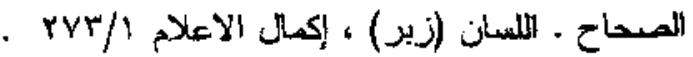


ومنه ما جاء في الحديث : ( الفقير الذي لنيس لذة زبز) أي عقل بعتمد

و الزّبزّ : الصبر ، و هو أيضاً : وضع البنيان بعضه على بعض .

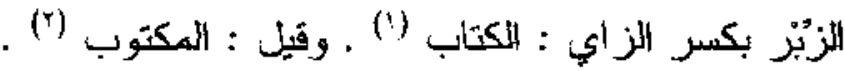

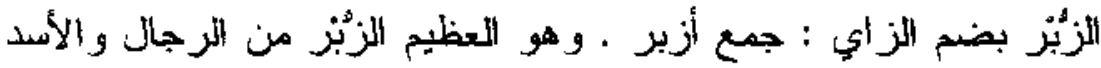

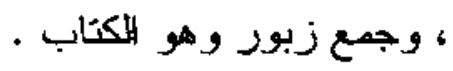

هكذا جاء المعنى الثاني في إكمال الأعلام

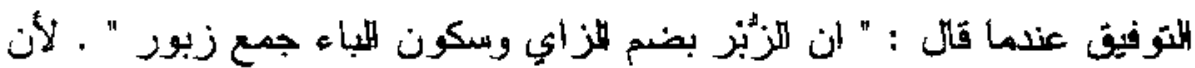

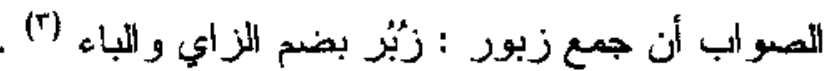

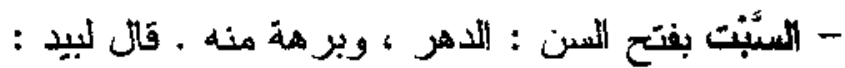

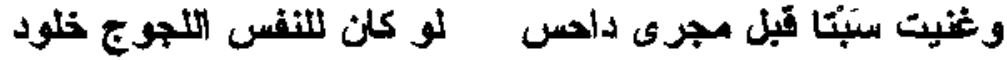

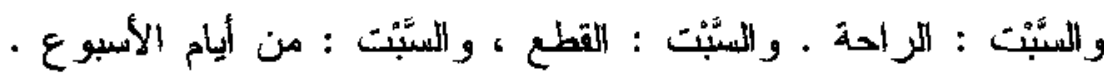

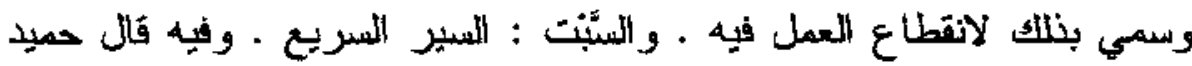

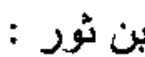

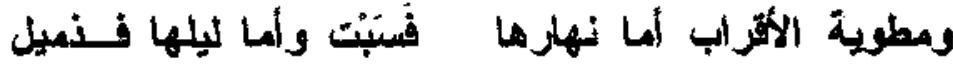

وقيل : هو سير فوق العنق ، وفيل : ضرب من السيز ، وقيل : السبق

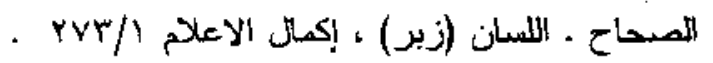

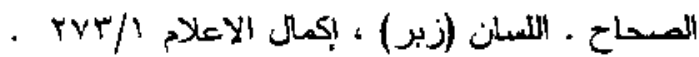

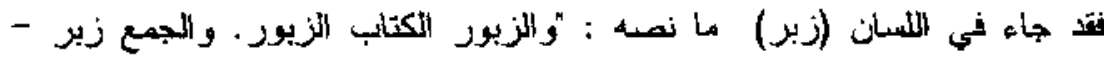

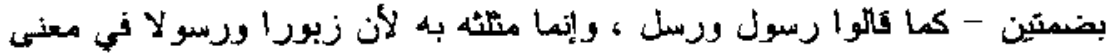

$$
\begin{aligned}
& \text { مغعول ـ قلى لنبيد : }
\end{aligned}
$$

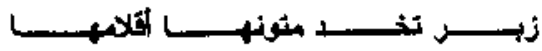


في العدو . فقد فيل : فرس سبت : لإذا كان جو الدا كثير العدو .

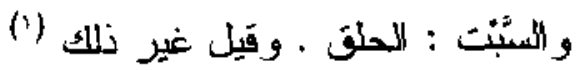

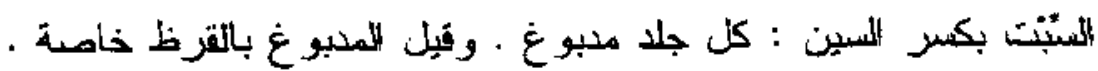

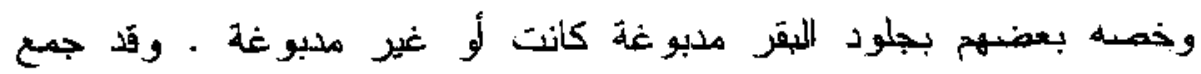
الجوهري بين كل ما مضى فخصها بجلود البر المدبوئة بالقرظ تحذى منه مئه النعال المبنتية .

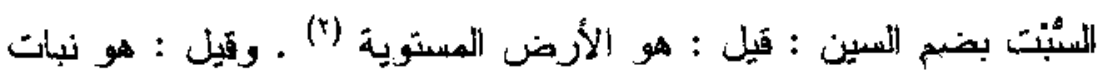

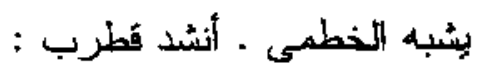

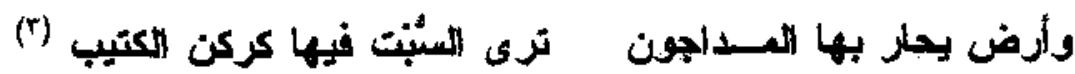

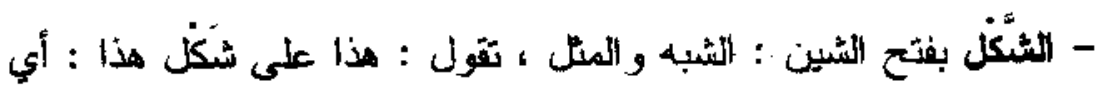

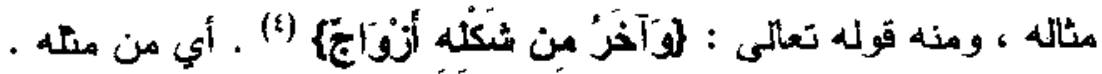
والمذهب ـ ثقول : هذا هن شكل هذا : أي من مذهبه . وما يو افق الإنسان ويملّ له ، و المسورة المحسوسة للثيء و المثر همة ، مصير شكل الكتاب و الدابية .

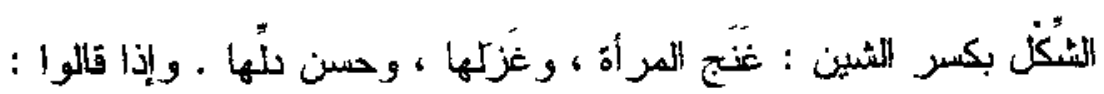

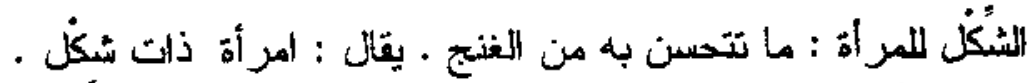

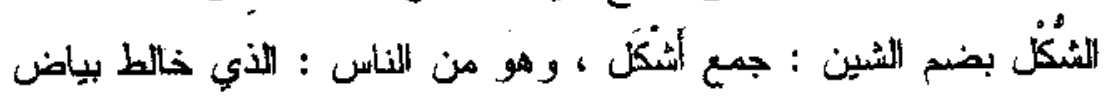

(1) القاموس المحيط (سبث) فتد جاء فيه : " وهو : الغلام العارم الجزىى ، والثلرجل

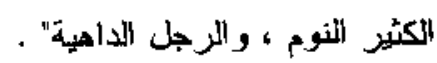

$$
\begin{aligned}
& \text { اكمال الاعلام ra. } 9 \text { r . } \\
& \text { الصحاح · اللسان (سببت) . }
\end{aligned}
$$

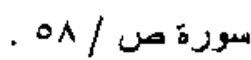


عينه حمرة . ومن الكباش : الأبيض الخاصرة . ومن سائر الحبوان . ما خالط سو أده حمرة أو غبرة .

وفيل : هو من سائر الأثبياء : ما اختط فيه البياض و الحمرة (1).

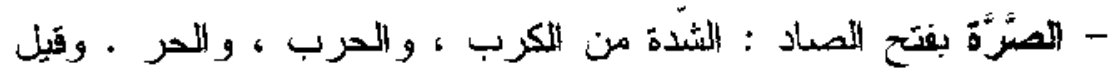

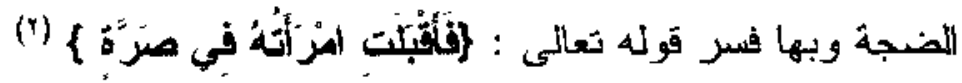

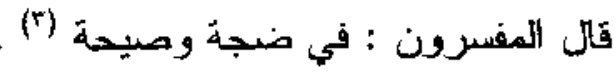

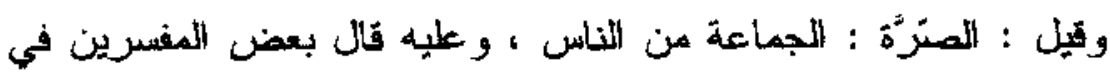
الآية المذكورة : أثبلت في جماعة .

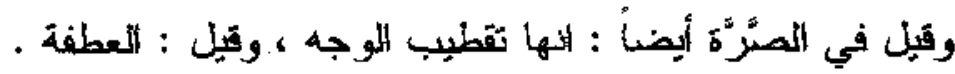

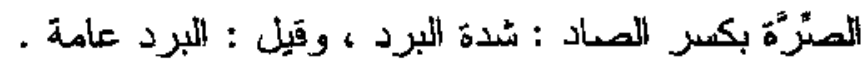

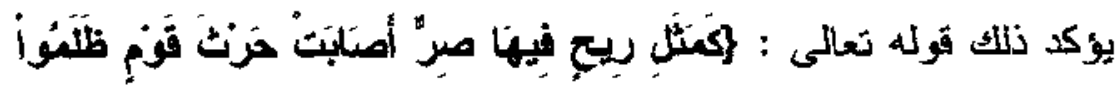

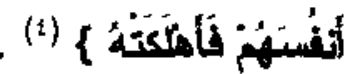

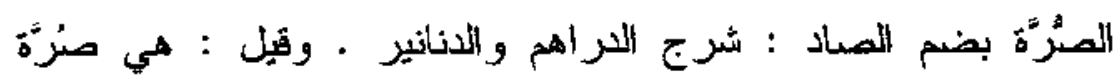

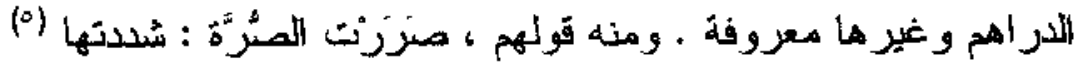

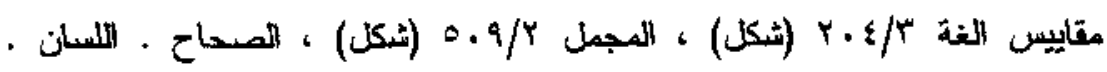

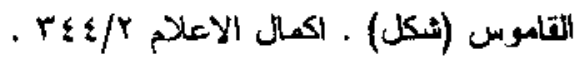

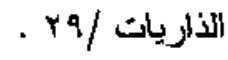

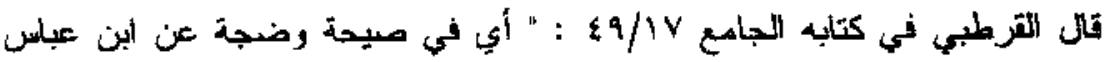

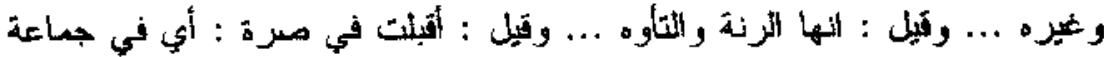

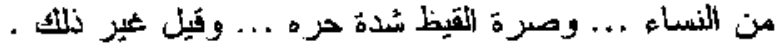

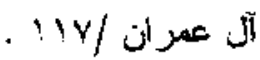

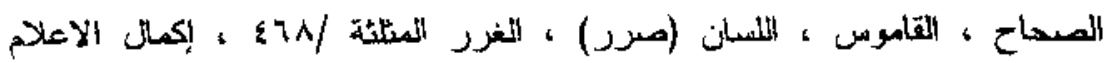




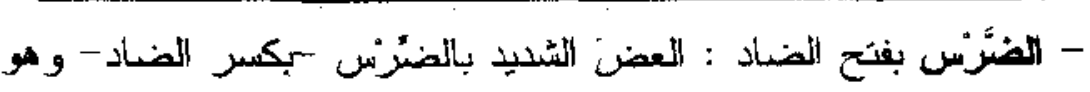

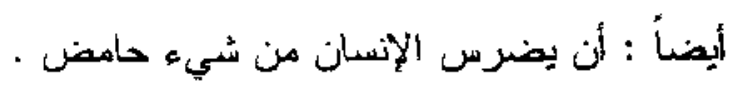

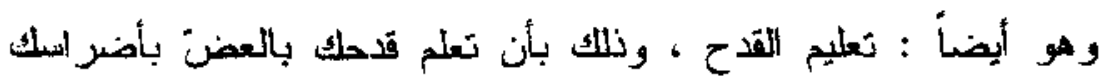

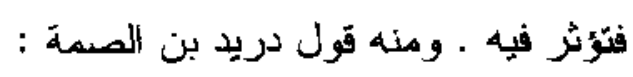

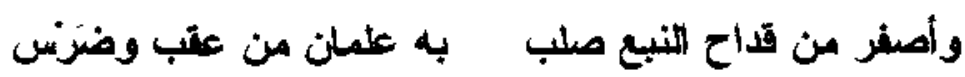

$$
\text { وقتيل أن الضَّرس : هو الحزّ الأي في وسط اللسهم . }
$$

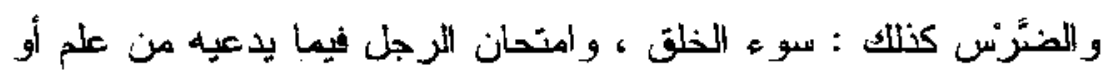

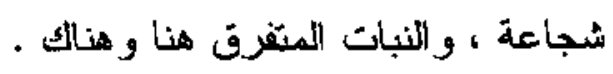

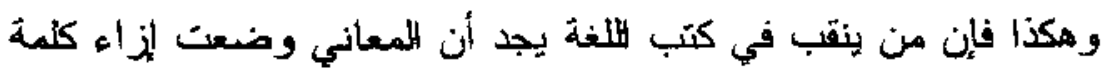

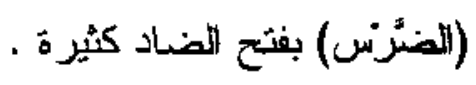

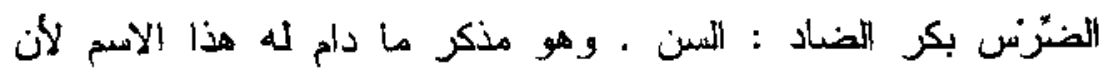

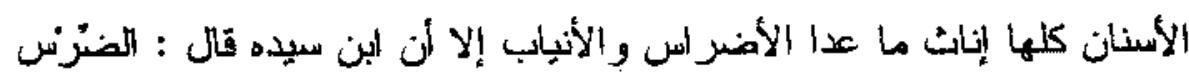

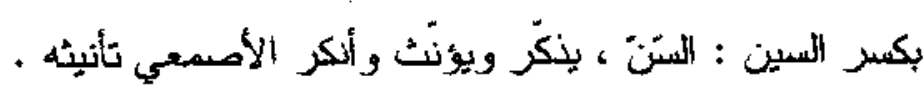

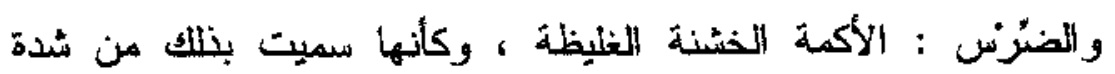

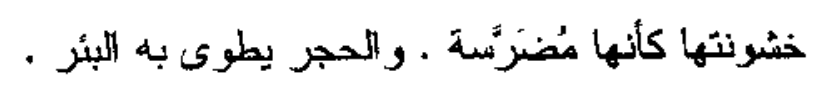

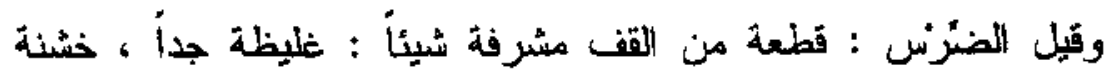

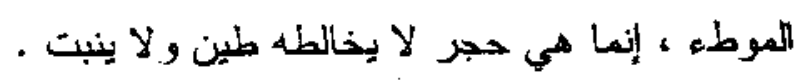

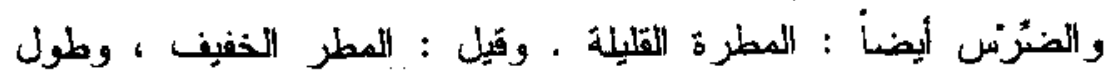

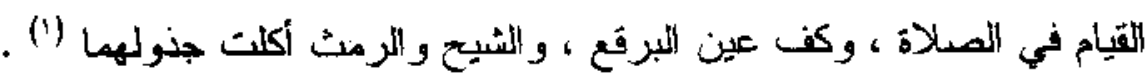

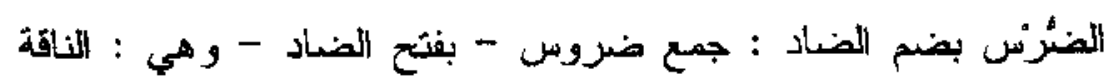

$$
\text { (الصحاح ، التلسان ، القاموس (ضرس) . }
$$


(1) التي تعض حأبها

- الطُرْت بفتح الطلاء : العين ، وقيل : طرف العين ، ومنه قول الشاعر :

فنض الطرف إتك من نُمير فلا كعبا بلغت ولا كلابا

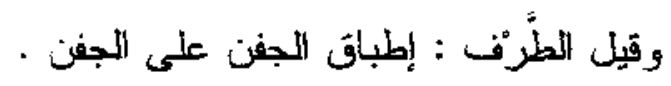

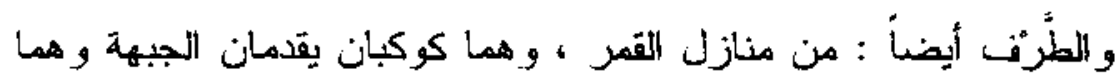

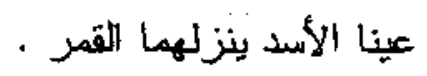

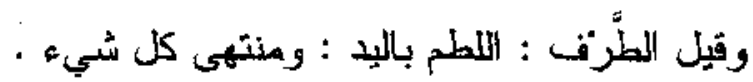

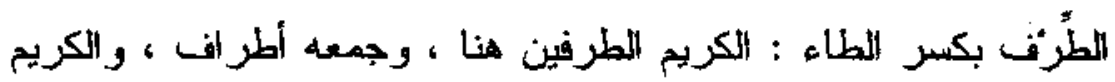

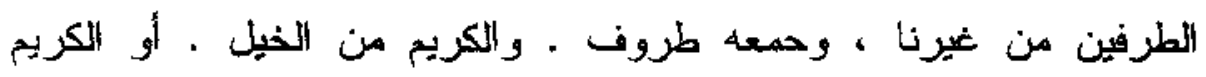

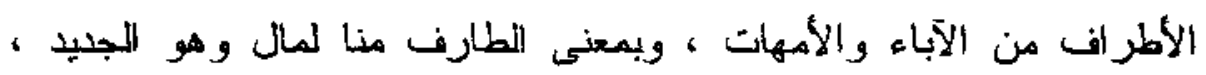

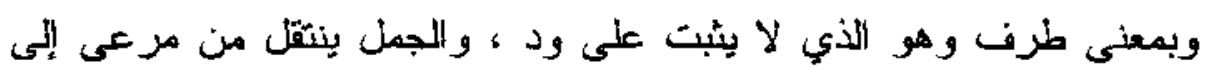

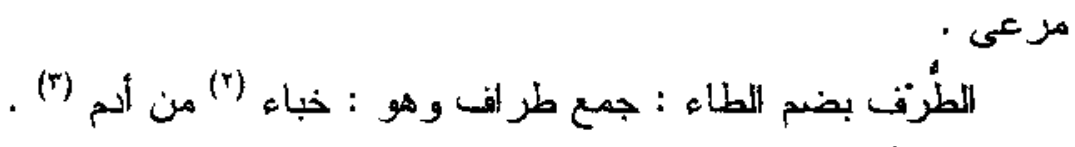
- الظلًّز بفتح الظظاء : من كل شيء : خلاء : خلف البطن ، وهو من الإنسان

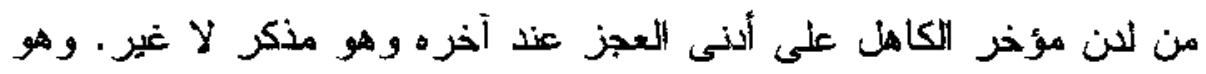

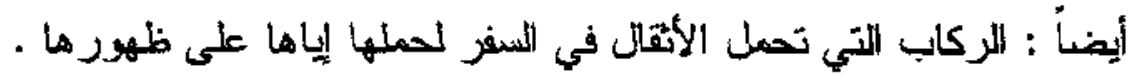
إكمال الاعلام rvy/r

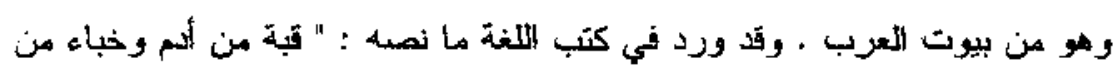

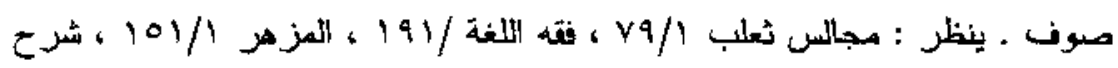

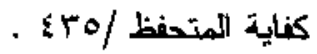

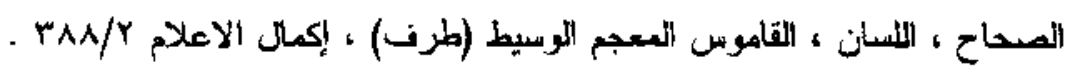




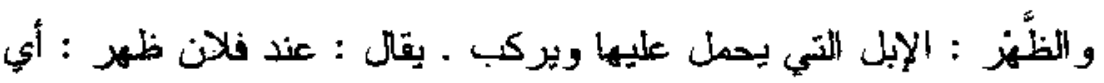

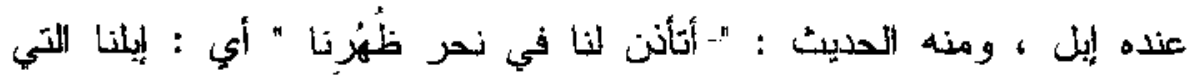

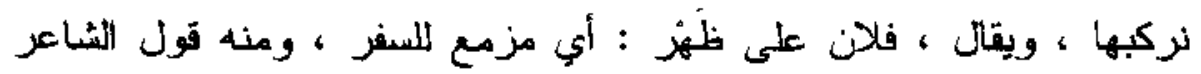

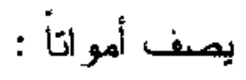

لو يستطيسون الرواح تروحوا معي أو غذوا في المصبحين على ظَّز

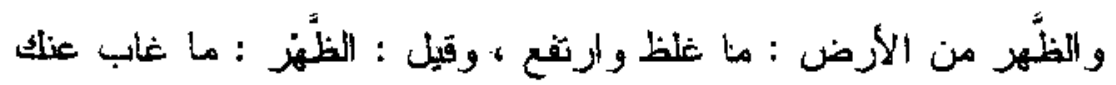

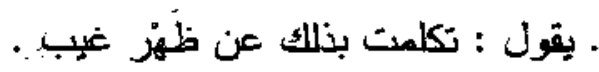

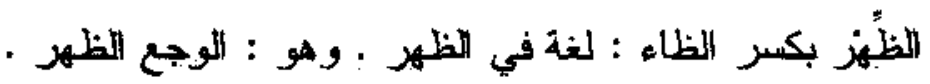

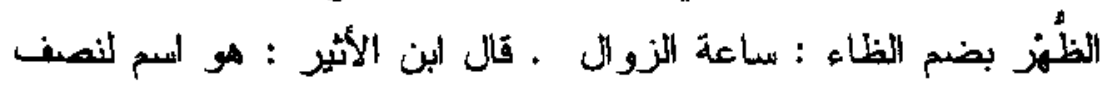

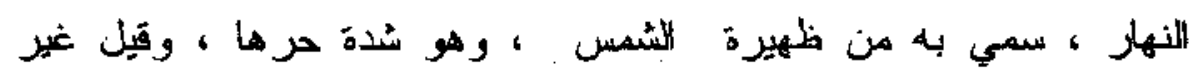
(1) - العزَس بفتح العين : عروس في وشيط اللفطاط .و الإحامة في الفرح

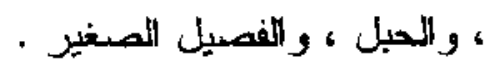
وحائط بين حائطي البيت المشتوي لا يبلغ به أقصاه ، و ويسقف لبيكن العِرنس بكر العين : امرأة الرجل ، ورجلها ، ولبؤة الأسد . قال الشاعر :

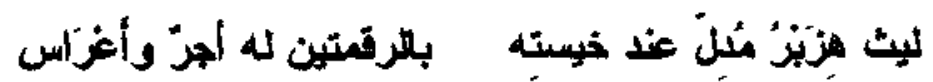


وربما سمى الأكر والأنتى عرسين · يؤيد ذلك قول علقمة :

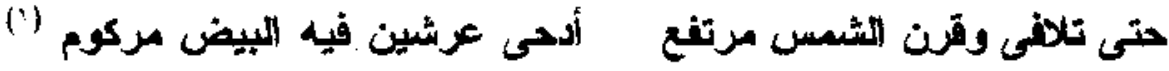

$$
\begin{aligned}
& \text { اللعُرنس بضم التعين : طعام اللوليمة ـ قالل الترأجز : }
\end{aligned}
$$

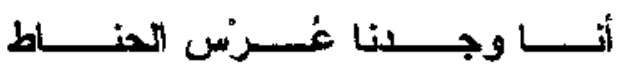

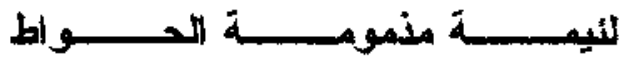

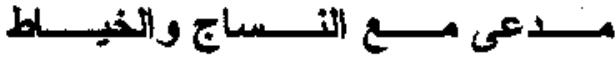

$$
\begin{aligned}
& \text { وقيل: طعام النكاح ، وقيل : النكاح نفسه (I) }
\end{aligned}
$$

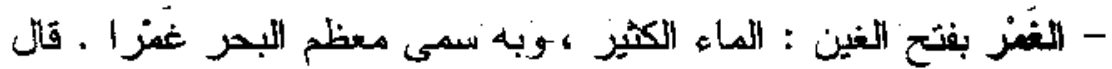

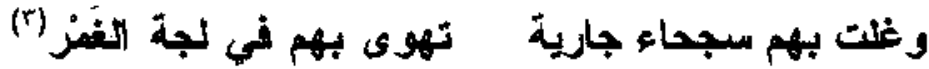

وغيل : هو الليل الطويل : و الثوبب المسابغ ، و الرجل الكثير الفضل

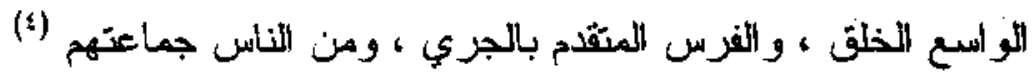

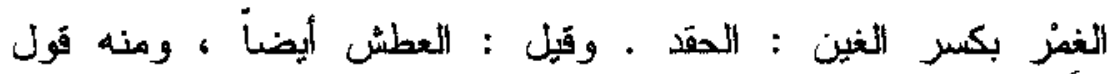

"حثى إذا ما بلت الأغنمارب

: العجاج

الغُمز بضم الغين : الذي لم يجرب الأمور (ه) .

$$
\begin{aligned}
& \text { مقاييس اللغة ك/171 (عرس) ، المصحاح ، القاموس (عرس) . }
\end{aligned}
$$

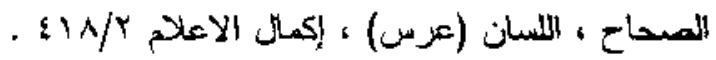

$$
\begin{aligned}
& \text { السجحاء الجارية هي : السفينة الطويلة الو أسعة . } \\
& \text { الجمهزة (رغم) ، إكمال الاعلام r/9 ع . }
\end{aligned}
$$

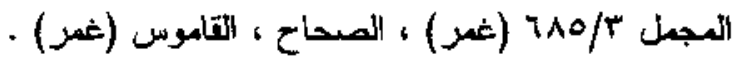




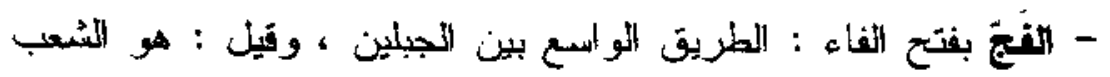

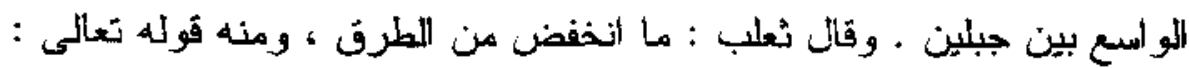

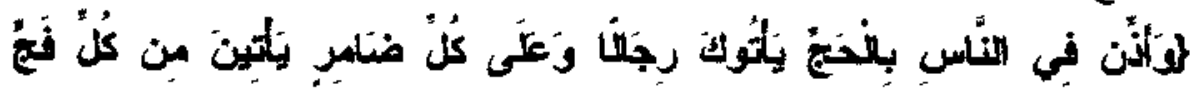

(1)

الفجز بكسر الفاء : البطيخ اللشامي اللذي تسميه الفرس : الاهندي ، وكل

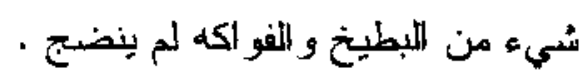

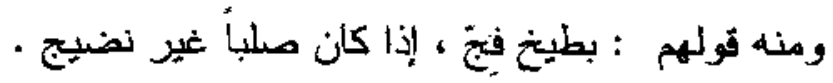

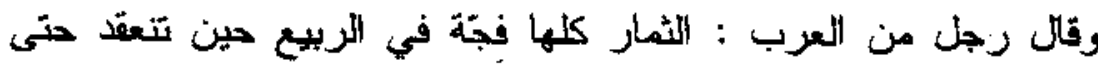

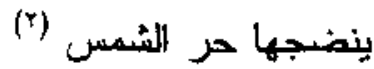

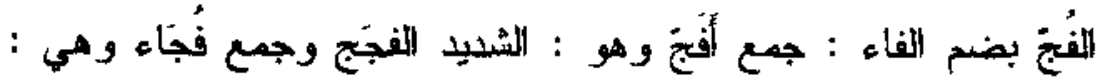

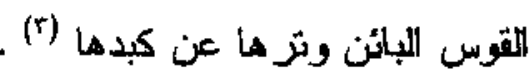

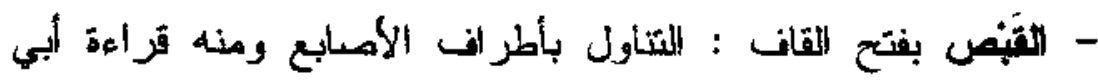

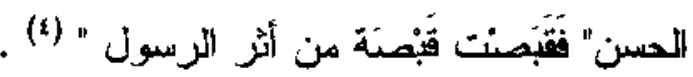

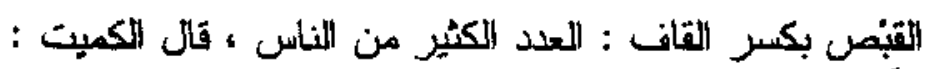

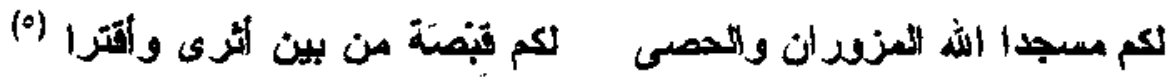

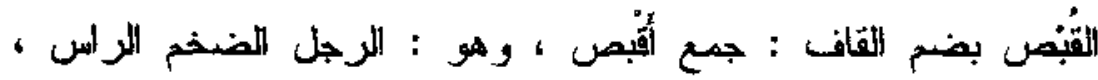

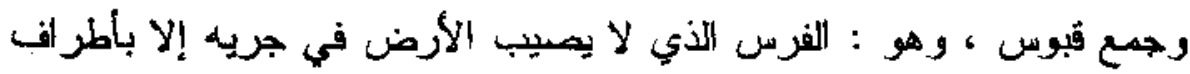

$$
\begin{aligned}
& \text { الحج/ } \\
& \text { القاموس ، الملسان ( فجج ) . } \\
& \text { إكمال الاعلام } \\
& \text { الصنحاح (تبص) . }
\end{aligned}
$$

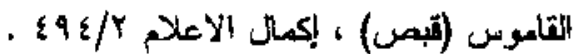


(1) (نابكه

- الكتف بفتح الكانف : مصدر كنف الثّيء : حفظله ، و عنه : عدل ،

و مصنر كنف الكيلا جمل بيليه على رأس القفيز بمسنك بهما لأحب .

الكنف بكسر الكاف : و عاء أداة الز اعي ، أو و عاء أسقاط التكاجر .

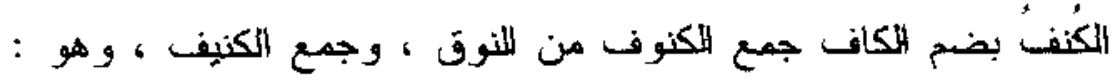

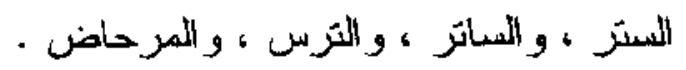

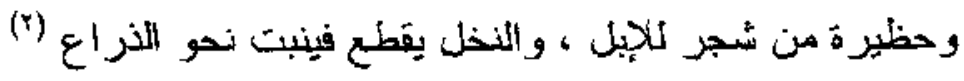

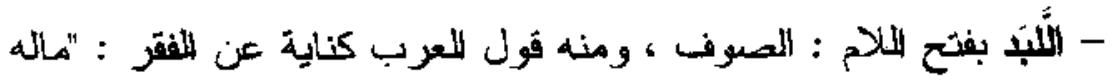

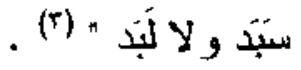

ومصبر "لبنت الإبل بالكسر تلبد لبدأ : لإذا دغصت من الصنتان - وهو

: اللثو اء في حبازيمها وفي غلاصمها ، وذلك إذا أكيرث مذه فتغص به .

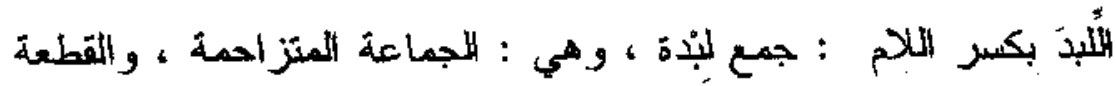

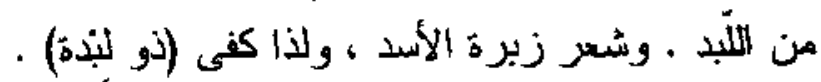

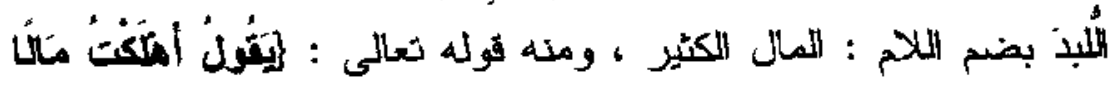

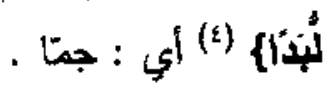

وهو أيضاً : اللرجل الذي لا يسافر ولا يبرح المكان ، وهو مأخوذ من "

$$
\text { - المجمل }
$$

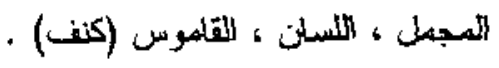

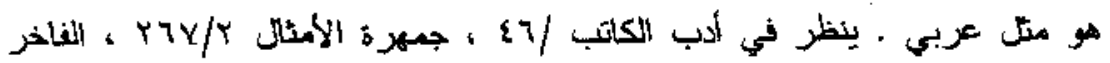

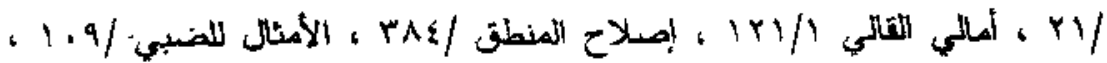

$$
\begin{aligned}
& \text { الصداك (لبد) ، اللسان (سبد لبد) . } \\
& \text { المبلد / } 7 \text { / }
\end{aligned}
$$


ألثبد بالمكان" أقام به (1)

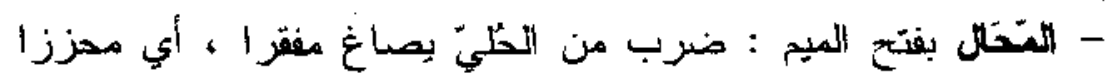

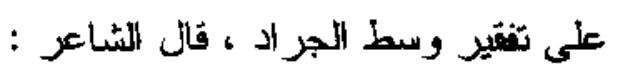

مخَل كأجواز الجراد ولؤلئ"

وفيل : هو البكرة العظيمة التي تستقي بها الالبل ـ قال حميد الأرقطة :

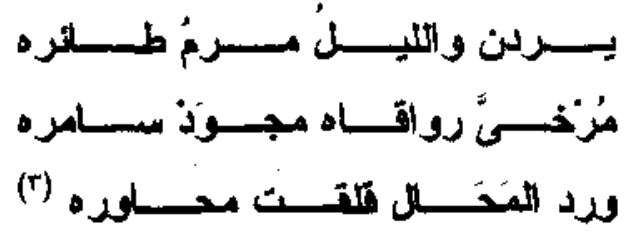

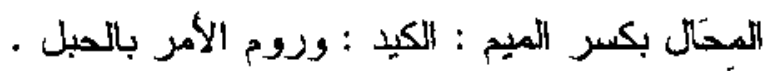

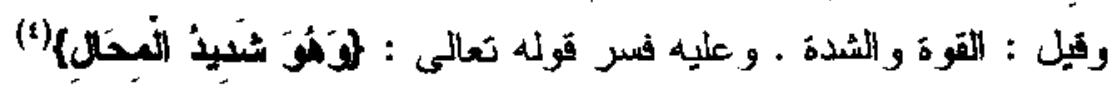

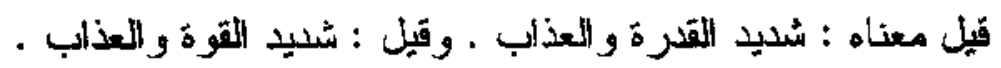

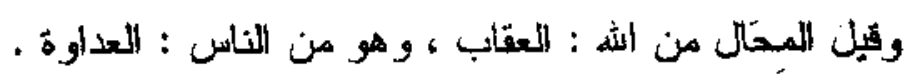

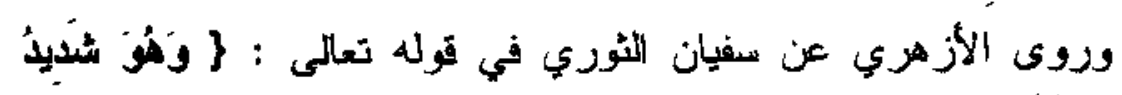

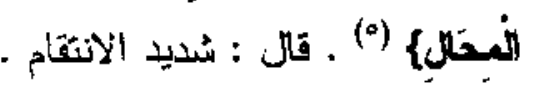

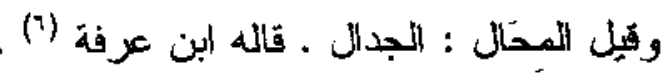

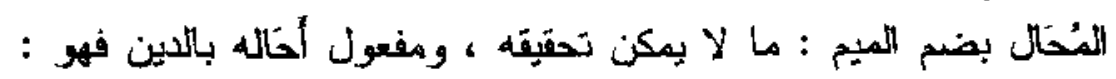

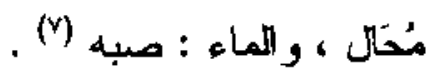

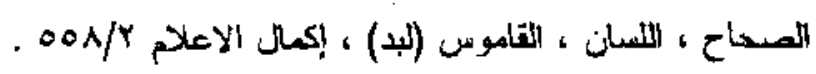

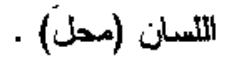

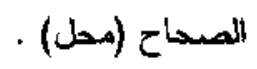

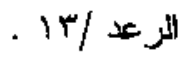

التزع /

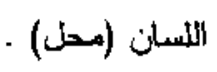

إكما الاعلام (1) 
- النَّنس بفتح النون : قلب الشيء على رأعهه ، وذذلك يجعل أعلاه

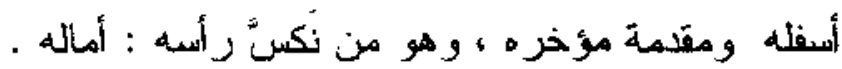

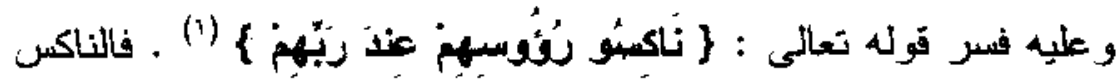

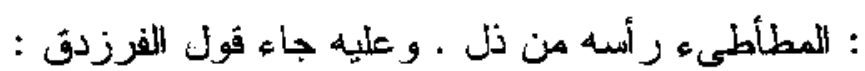

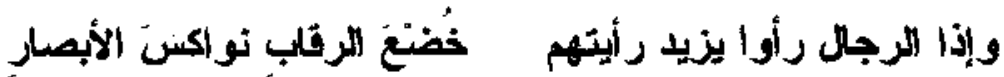

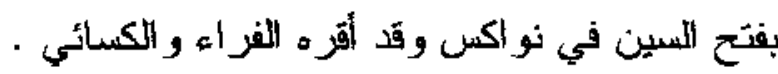

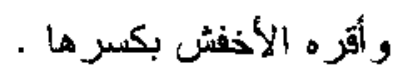

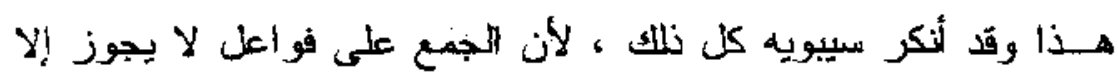

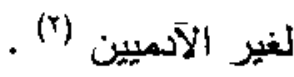

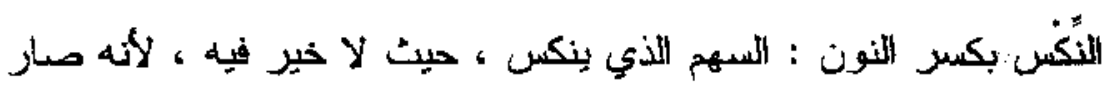

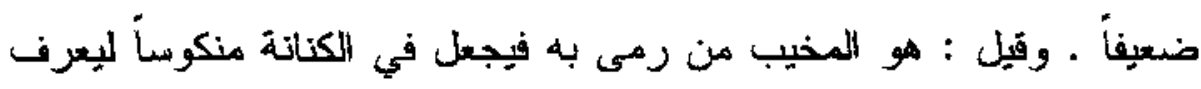

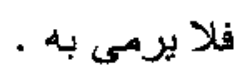

ويثيل : هو القصير ، ومن الرجال : المقصر عن غاية النجدة والكرم .

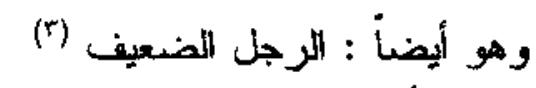

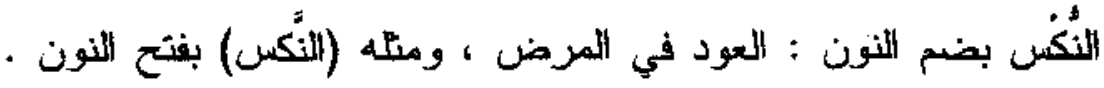

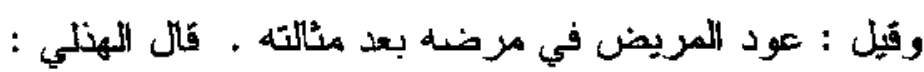

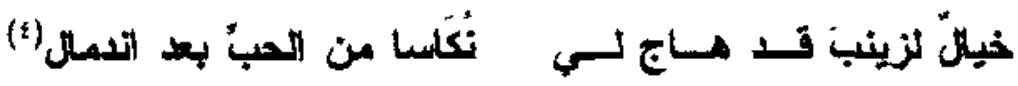

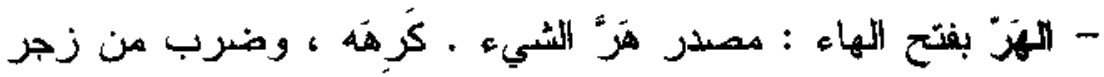

$$
\begin{aligned}
& \text { العجدة/ 1Y) } \\
& \text { الثلسان (نكس) . }
\end{aligned}
$$

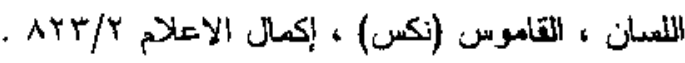

$$
\begin{aligned}
& \text { اللسان ، المعجم الوسيط (نكس) . }
\end{aligned}
$$




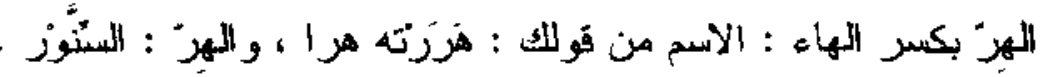

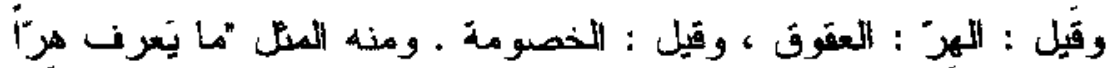
من بِر" (1)

وقيل الثهر" : سوق الغنم ، وقيل : دعاء للاننم البلى العلف ، وقيل : إلى بلى

وهِ" : بلا ، ورأس هِر" : موضع في ساحل فارس يِ ابط فيه . قال الشاعر :

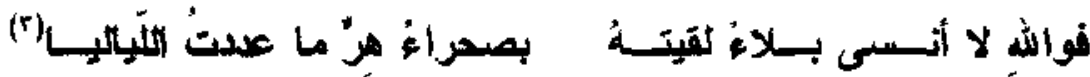

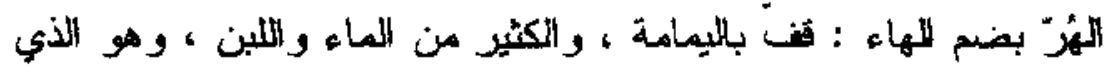

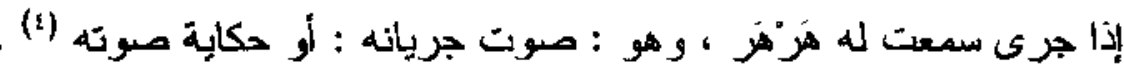

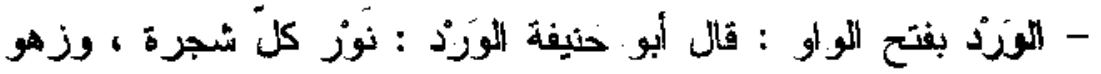
كل نبت ... والوزّد بيلاد العرب كثير · ريفية ، وبرية ، وبلية .

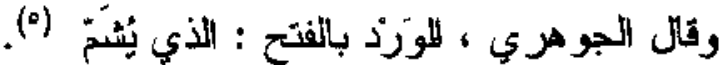

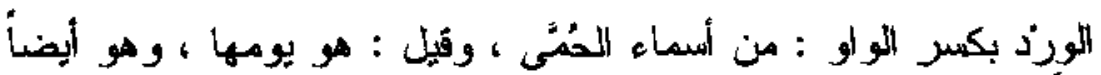

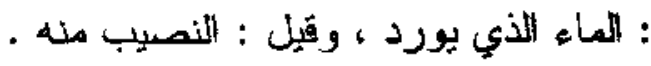

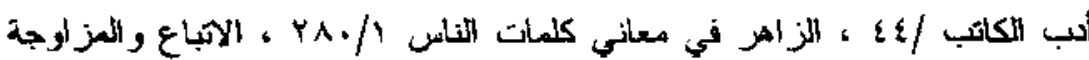

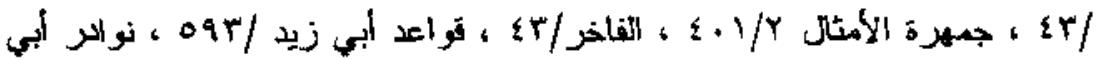
سحل

الثلسان ، القاموس (هزر) .

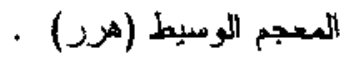

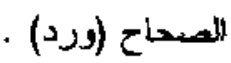


وقيل : النصيب من الققر آن . تقول قرَأت ورِدي : أبي نصبيهي ومقداري

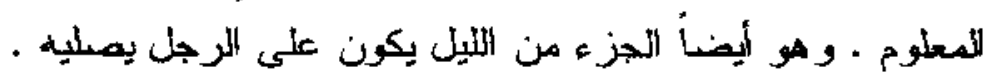

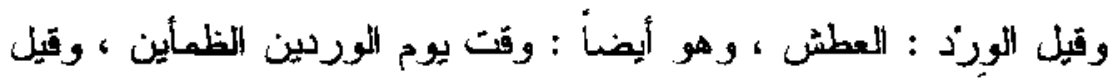

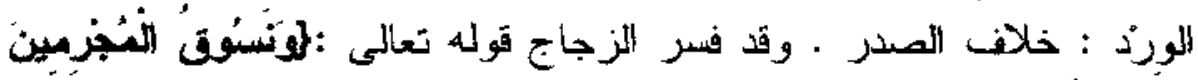

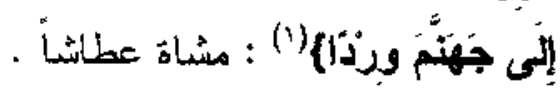

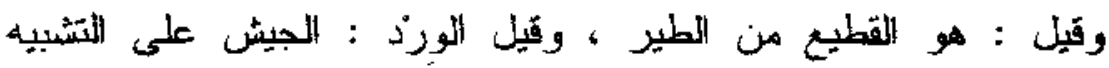

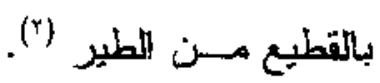

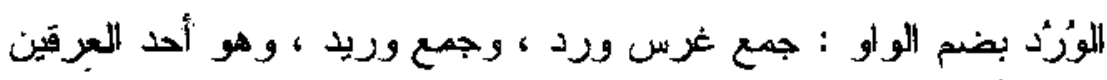

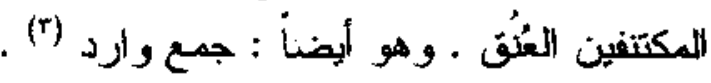

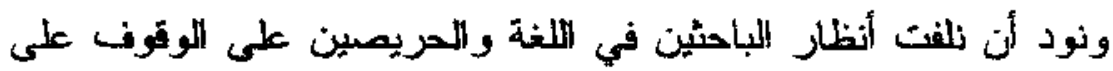

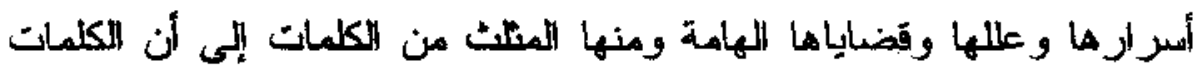

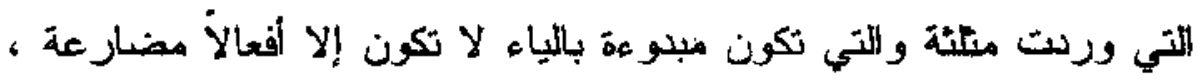

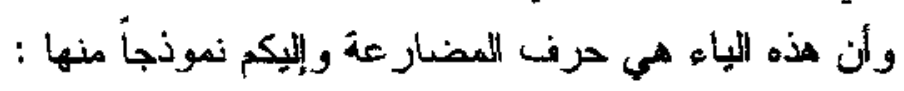

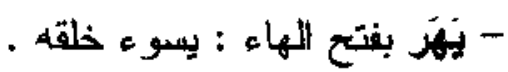

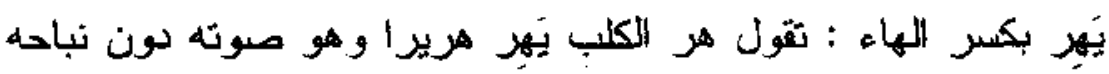

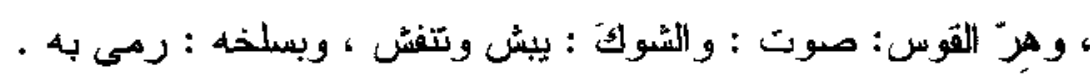

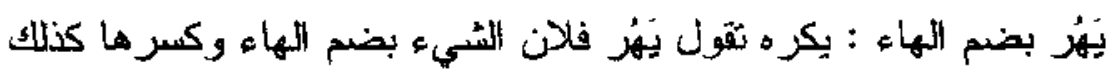

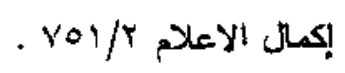

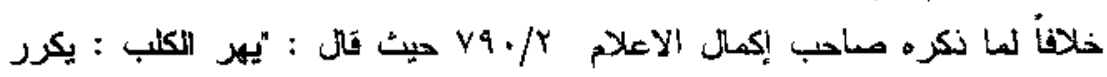




\section{نتشتب البهد}

النحمد اله الذي هدانا لهذا وما كنا لنهيّي لولا أن هدانا الله ، ونصلي

ونسلم على أشرف خلقه ومصطفاه سيدنا وحبينا وأمامنا محمد ابن عبد الثله ، ملوات الله وسلامه عليه و على آله ومعبه ومن والاه . …

فهذه بعض النتائج التي توصلت - بئوفين الله - إليها و ويى :

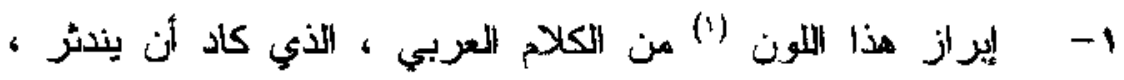

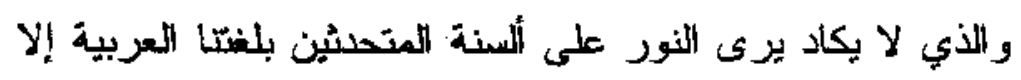

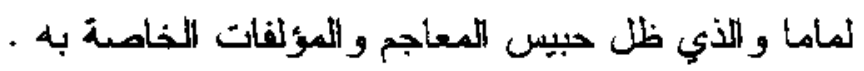

r - بتبيه الباحنين و الدارسين ، والفت نظرهم إلى كقة اللغة العربية

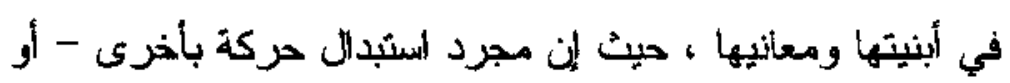

حركتين - على بناء واحد يؤدي - في معظم الحالاتت - إلى

تغييز المعنى، ، مما بتزتب عليه تحقيت الغنى و الثراء للغتيا

$$
\text { العريية . لعبية }
$$

وهـو بخلتف يكون كون أنىى شك - عاملاً هامأ من عوامل

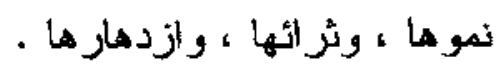

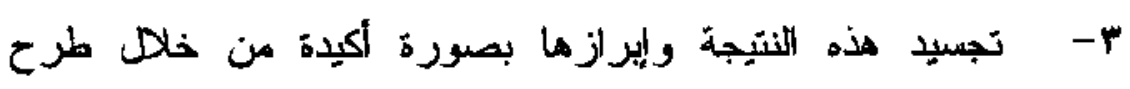
وشرح مختاز ات من الألفاظ المثلثة الفاء لتزبسخ هـذه المعالجة

$$
\text { في نفوس اللباحثين في لغنتا المعربية. }
$$

وهذه النتيجة هي : نمو اللغنة وئراؤها عن طريق تعدد المعاني

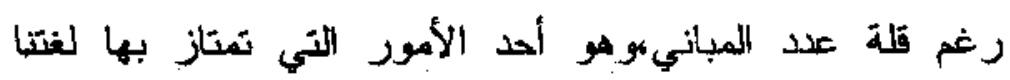

$$
\text { (1) وهو : المثلثث من الكلام العربي . }
$$


الكربية على سائز اللغات البشرية.

؟ - لفت نظر الباحثين إلى هذا اللون من المثلثدات وأثره في نمو اللغة

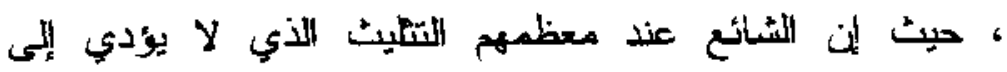

$$
\text { اختلاف المعنى . المبن }
$$

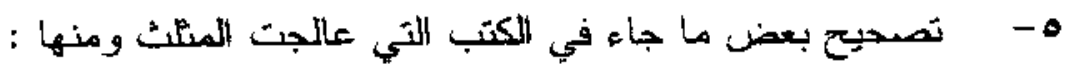

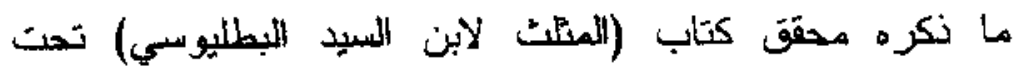

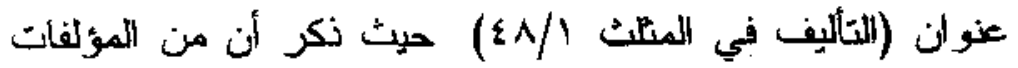

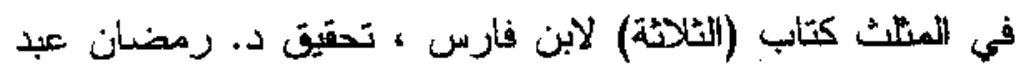

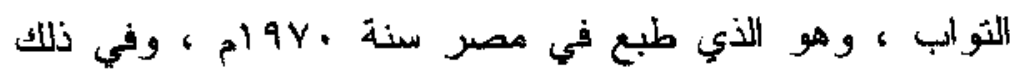

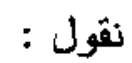
أن هـذا الكتاب لا بعد أبداً من الكتب الثي ألفت في المتيث من

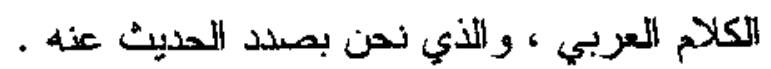

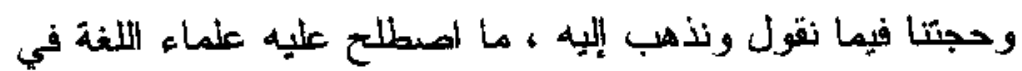

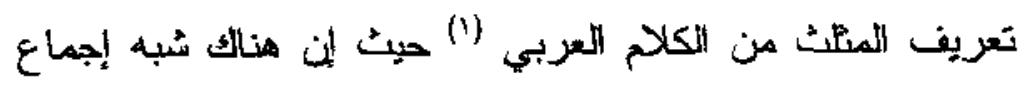

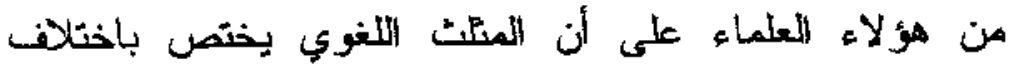

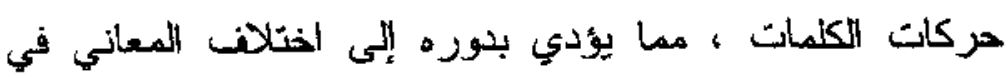

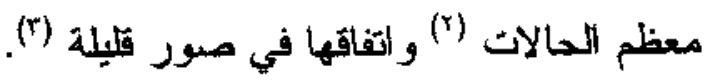

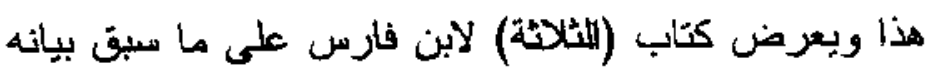

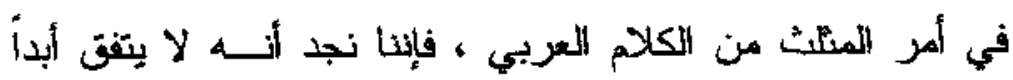

وهر المثتث المختلف المعاني .

ومو المثاث المثنق المعاني .. 


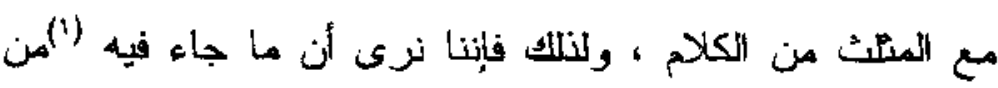

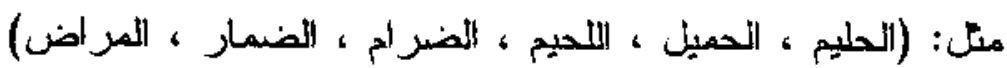

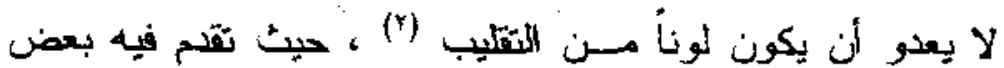

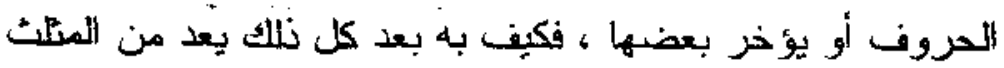

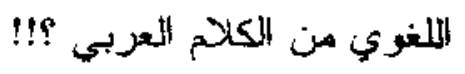

צ- الإفادة الشخصية الكبيزة ، و اللتعرف عن كثب على إحدى مزايا

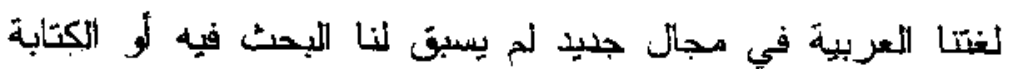

$$
\text { عنه . }
$$

هذه عن بعض الأتائج التي توصلنا إليها في هذا البحث .

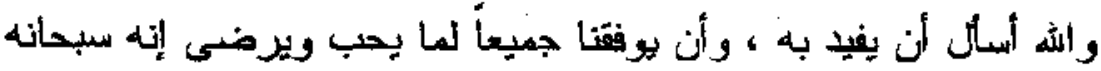

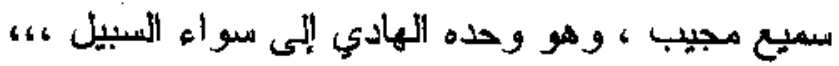

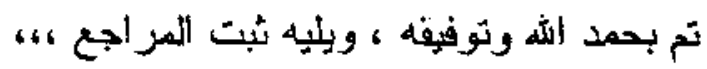

$$
\text { د. علي بن عبد الثله المرأجحي }
$$

\section{أستاذ فته اللغة المساعد في كلية اللغة العريية}

$$
\text { بجلمعة القصبيم }
$$

$$
\text { أي ني كتاب (النثلاتة) . }
$$

وند ذكر المحتق ذلك إلا أنه كان عليه عحم نكره أصلاذ في المؤلفات في المتثلات

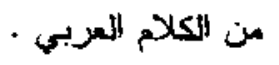




\section{"ثبت المباجع "}

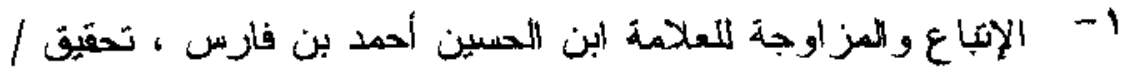

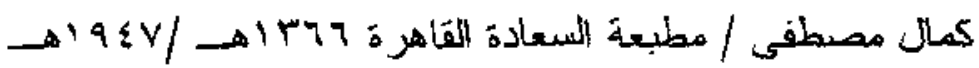

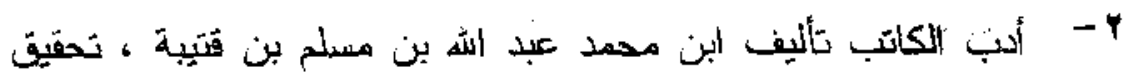

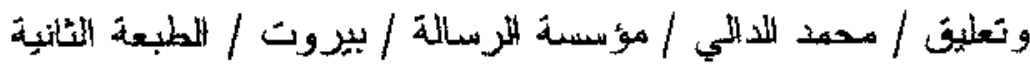

$$
\text { 1910/ - 1980 }
$$

r- أسناس البلاغية للعلامة ابن اللقاسم محمود بن عمر بن أحمد

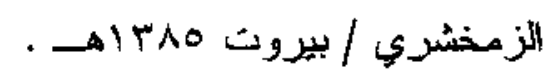

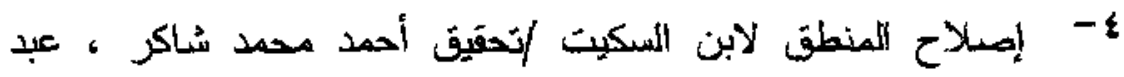

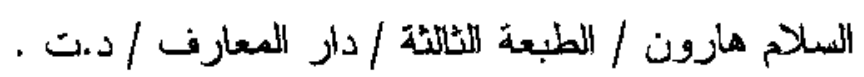

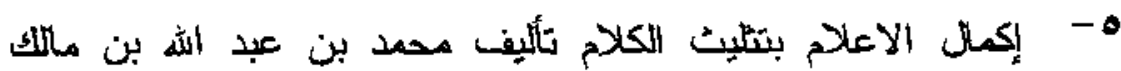

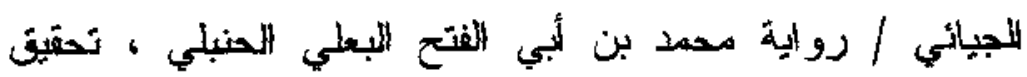

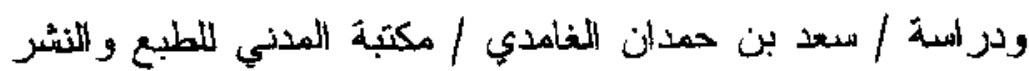

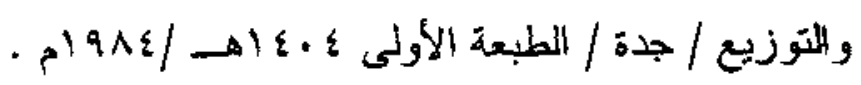

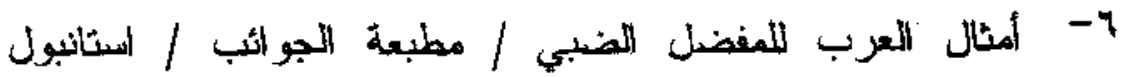

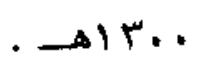

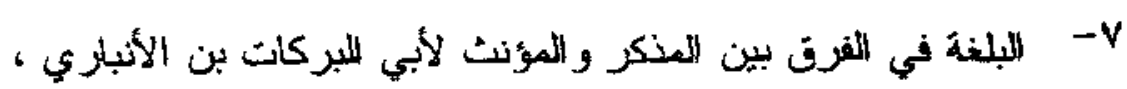

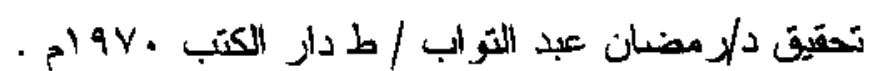

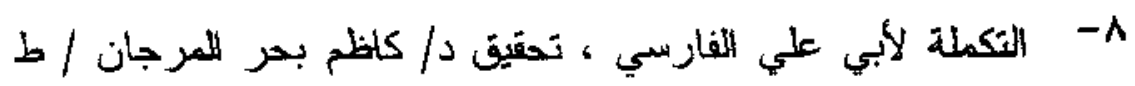

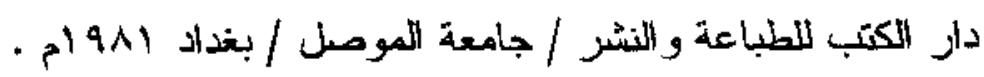

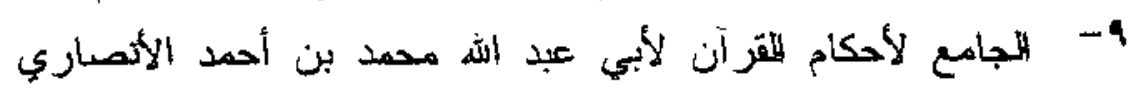

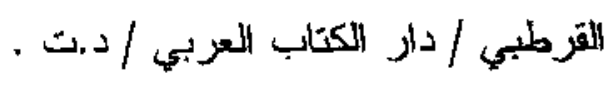




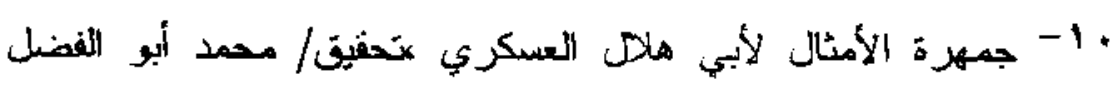

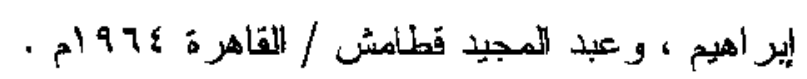

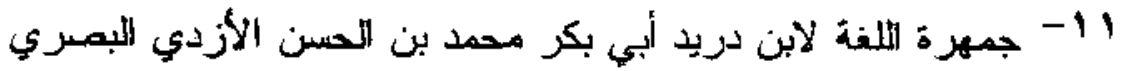

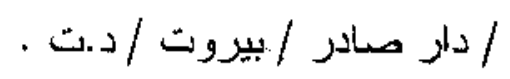

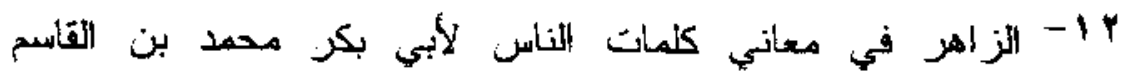

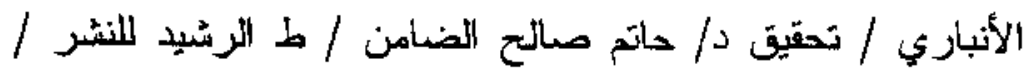

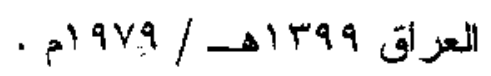

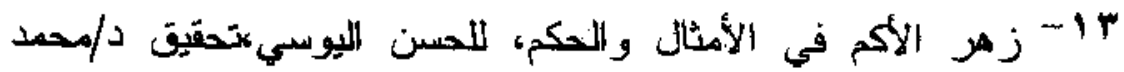

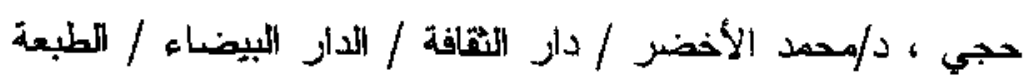

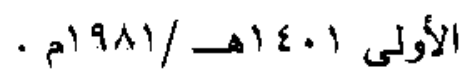

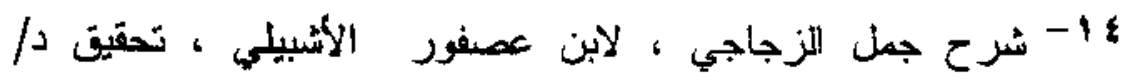

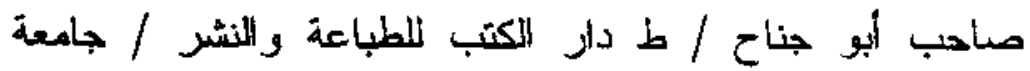

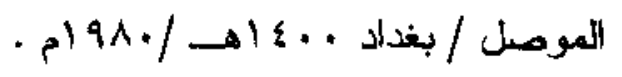

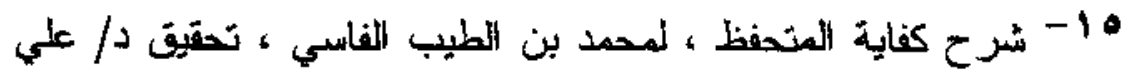

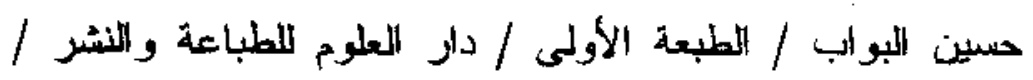

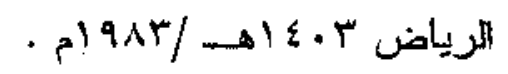

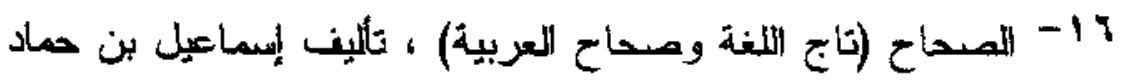

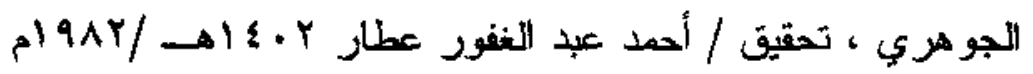

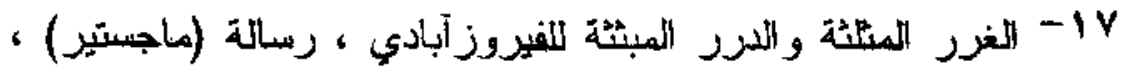

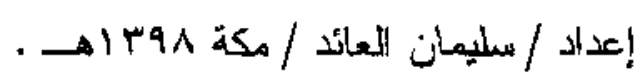

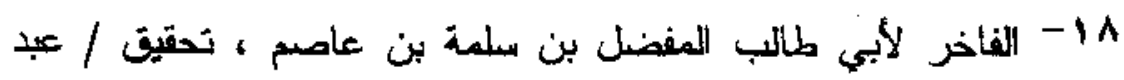

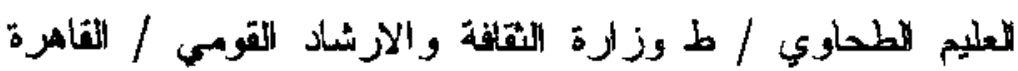




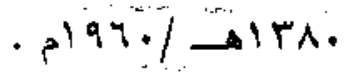

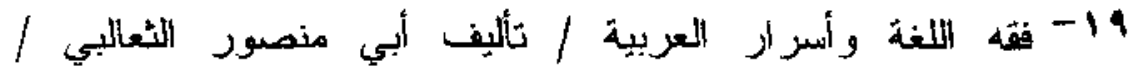

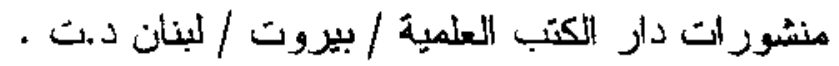

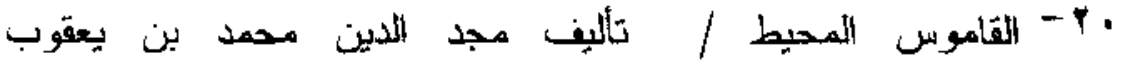

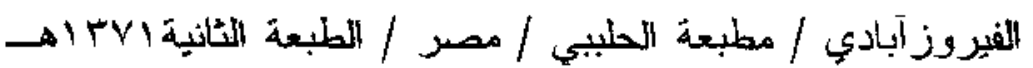

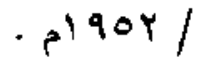

ا ا-Y- كتاب الأمالي / كأليف أبي علي إسماعيل بن اللقاسم القالي

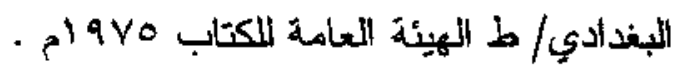

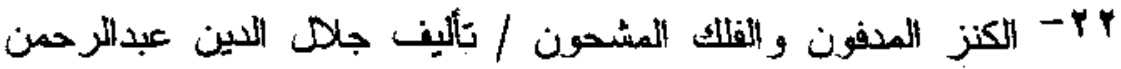
السيوطي / الطبعة الر ابعة / مصطفى البابي الحلبي / مصر

$$
\text { - 1907/PrVT }
$$

rr أب- لسان العرب لابن منظور / ط دار المعارف / القاهرة / د.ت.

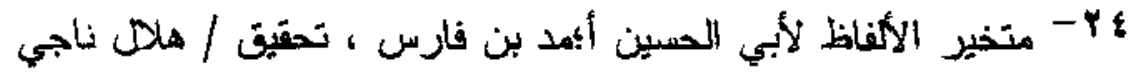

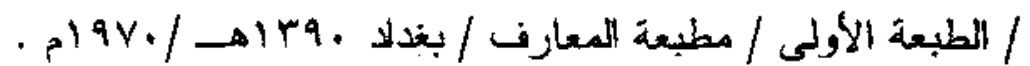

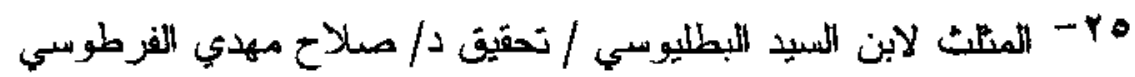

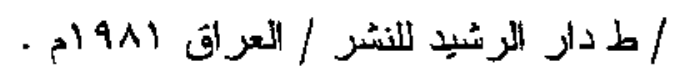

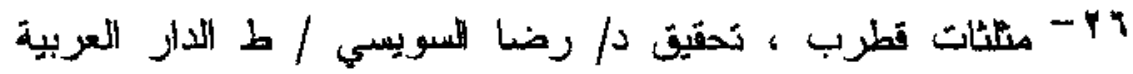

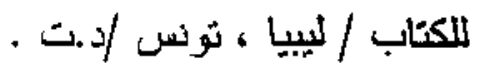

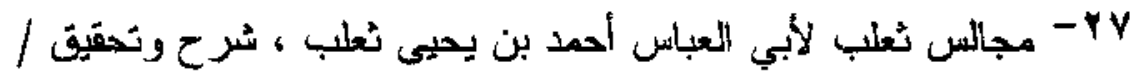

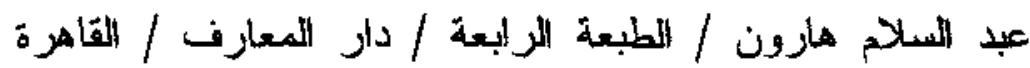

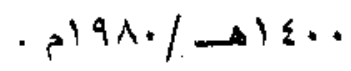

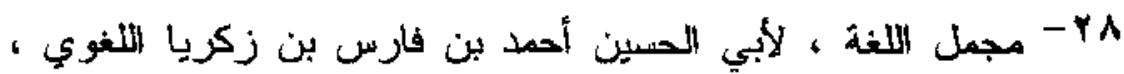

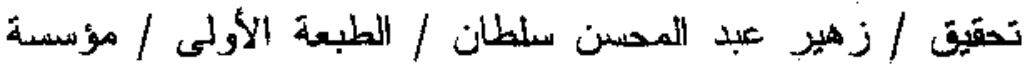




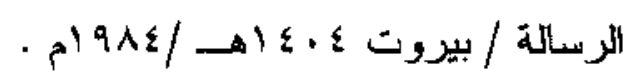

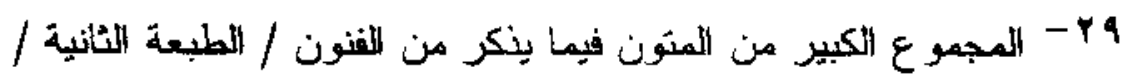

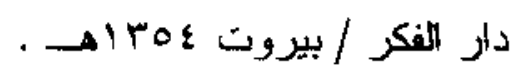

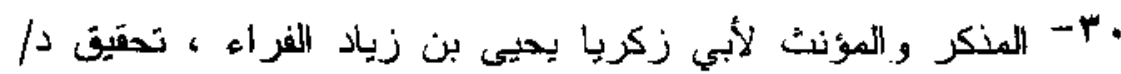

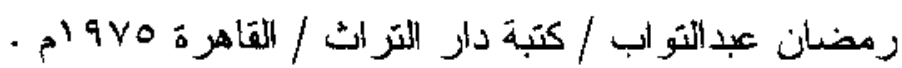

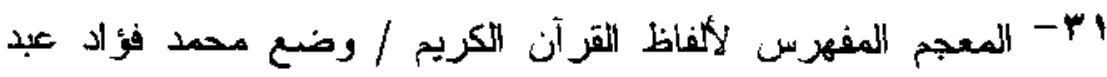

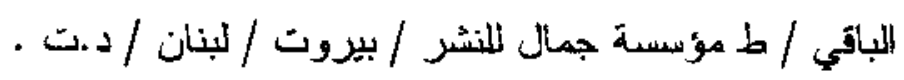

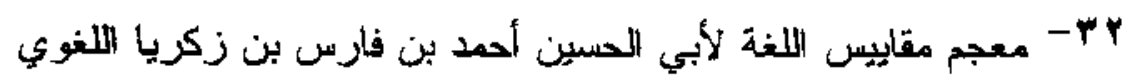

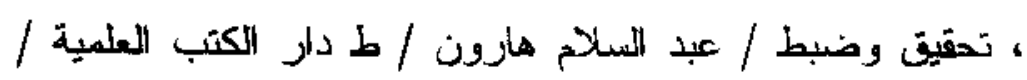

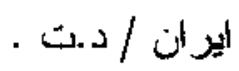

rr- المعجم الموسيط ، إخر اج / إير الهيم مصطفى ، أحمد حسن الزيات

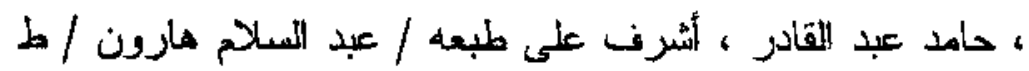

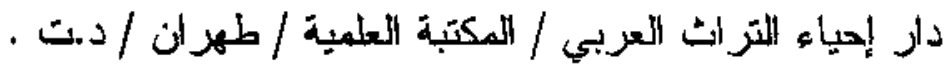

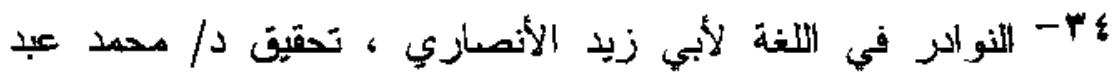

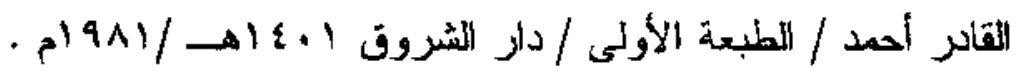

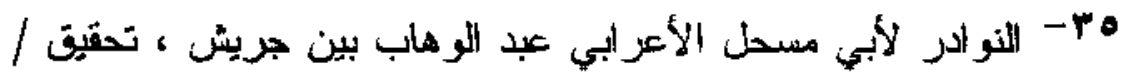

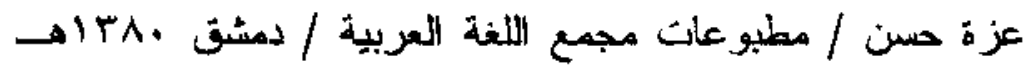
. 
